Portland State University

PDXScholar

5-18-1979

\title{
The Bureau of Land Management and Cultural Resource Management in Oregon
}

William James Cannon

Portland State University

Follow this and additional works at: https://pdxscholar.library.pdx.edu/open_access_etds

Part of the Archaeological Anthropology Commons, Cultural Resource Management and Policy Analysis Commons, and the History of Art, Architecture, and Archaeology Commons Let us know how access to this document benefits you.

\section{Recommended Citation}

Cannon, William James, "The Bureau of Land Management and Cultural Resource Management in Oregon" (1979). Dissertations and Theses. Paper 2906.

https://doi.org/10.15760/etd.2902

This Thesis is brought to you for free and open access. It has been accepted for inclusion in Dissertations and Theses by an authorized administrator of PDXScholar. Please contact us if we can make this document more accessible: pdxscholar@pdx.edu. 
AN ABSTRACT OF THE THESIS OF William James Cannon for the Master of Arts in Anthropology presented May 18, 1979.

Title: The Bureau of Land Management and Cultural

Resource Management in Oregon.

APPROVED BY MEMBERS OF THE THESIS COMMITTEE:

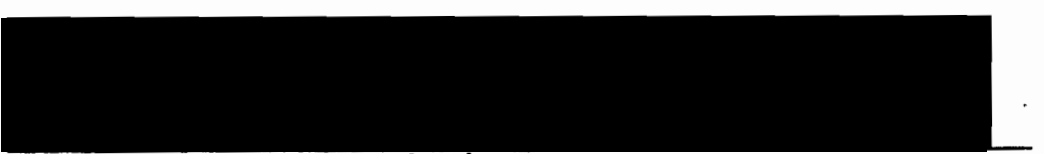

Thomas Newman, Chairman

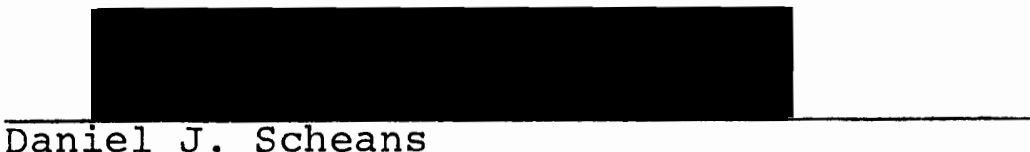

Daniel J. Scheans

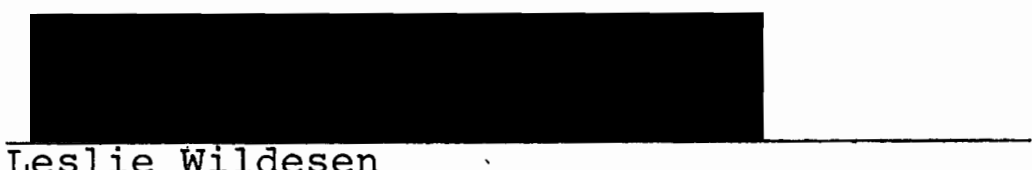

This thesis is an examination and descriptiun of the United States Department of the Interior, Bureau of Land Management's program for the management of cultural resources in the state of Oregon. The author has worked for the Bureau from March, 1975 to the present as a District cultural resource specialist.

The major emphasis of the thesis is a description and explanation of the Bureau's cultural resource management program and its major problems in relation to the taxpayer and archeologists. 
The data reported in the thesis were obtained through participant observation both as a graduate student from Portland State University conducting cultural resource work under contract and as a Bureau employee. Background information was obtained from published materials and individuals actively involved in cultural resource management today.

Areas of specific conflict between the Bureau, the public, and the non-federal archeologist include:

(1) Communication

(2) Contracting

(3) Relationship with the public

(4) Training for careers in cultural resource management

(5) Protection of cultural resources

(6) Methods of doing cultural resource management work

In the final chapter, suggestions are offered for solutions or changes which would eliminate or reduce the level of conflict between the three parties in the future. 
THE BUREAU OF LAND MANAGEMENT AND CULTURAL

RESOURCE MANAGEMENT IN OREGON

by
WILLIAM JAMES CANNON

A thesis submitted in partial fulfillment of the requirements for the degree of

\author{
MASTER OF ARTS \\ in \\ ANTHROPOLOGY
}

Portland State University

1979 
TO THE OFFICE OF GRADUATE STUDIES AND RESEARCH:

The members of the Committee approve the thesis of William James Cannon presented May 18, 1979.

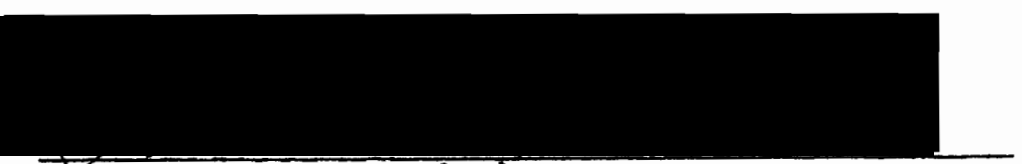

Thomas Newman, Chairperson

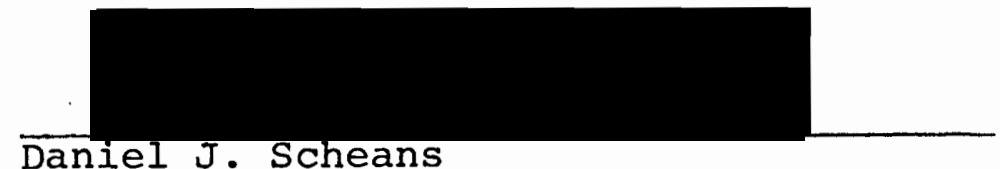

Daniel J. Scheans

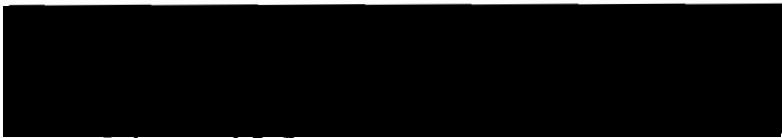

Leslie Wildesen

APPROVED :

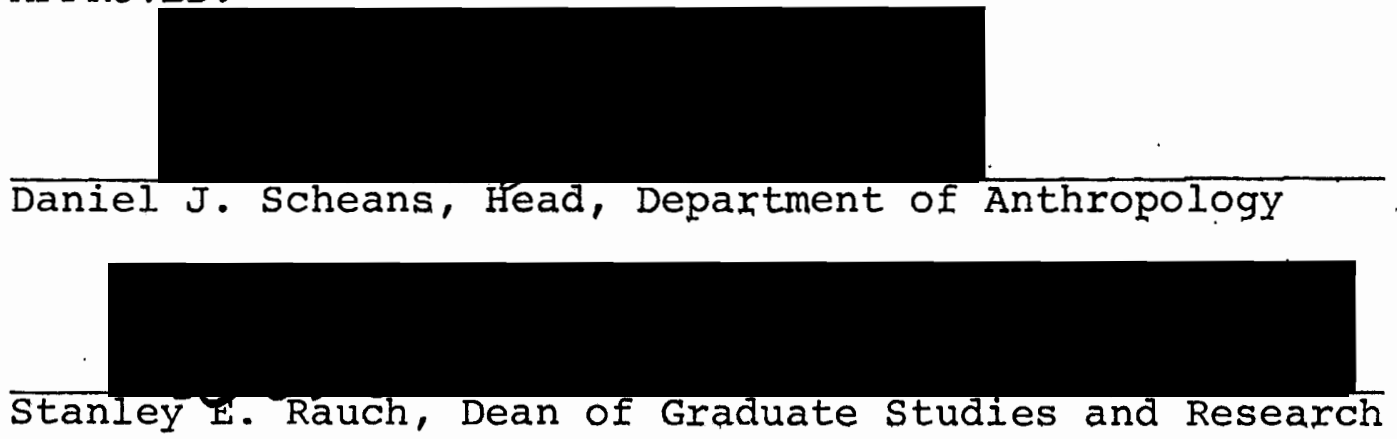




\section{ACKNOWLEDGEMENTS}

Thanks to my Committee, Thomas Newman, Daniel Scheans, and Leslie Wildesen, for their time, advice, and patience. Thanks to all the fellow graduate students who offered support and encouragement to complete this thesis, especially to Mary Ricks, Marilyn Couture, Ruth McGilvra, Roger Wiggin, Bob Bogue, and Phylis Lancefield.

Most of all, thanks to my wife, Janine, who kept me working on the idea and would not let me stop. Thanks to my daughter, Kelly, who waited patiently for the thesis to be finished so that evenings could once again be spent together as a family. 
TABLE OF CONTENTS

PAGE

ACKNOWLEDGMENTS • • • • • • • • • • • • • • •

LIST OF TABLES

vii

CHAPTER

I INTRODUCTION . . . . . . . . . . . . . I

II A REVIEW OF CULTURAL RESOURCE MANAGEMENT • 6

The Legal Basis for Cultural Resource

Management . . . . . . . . .

1906. Antiouities Act

Mineral Leasing Act of 1920

Historic Sites Act of 1935

National Trust for Historic

Preservation Act of 1948

Federal Aid Highway Acts of 1956 and 1958

Reservoir Salvage Act of 1960

National Historic Preservation Act of 1966

Department of Transportation Act of 1966

Intergovernmental Cooperation Act of 1968

National Environmental Policy Act of 1969

Geothermal steam Act of 1970

Presidential Executive Order 11593

Archeological and Historic Preservation Act of 1974

Federal Land Policy and Management Act of 1976

Code of Federal Regulations

Archeologists and Cultural Resource

Management . . . . . . . . . . 
Contract Archeology

Conservation Archeology

Public Archeology

Historic Preservation

III THE PRINCIPAL PARTIES . . . . . . .

The Non-Federal Archeologist . . . .

Contracting

Public Relations

Inventory and Material Storage Services

Historians, Architects, and

Anthropologists . . . . . . . .

Native Americans . . . . . . . 54

The Public . . . . . . . . 55

The Interested Public

The Apathetic Public

Other Parties of Importance $L_{p}$. . . .

State Historic Preservation Office

United States Forest Service

Heritage Conservation and Recreation Service

Advisory Council on Historic

Preservation

Office of Personnel Management

Other Federal Agencies

Bureau of Land Management . . . .

Organization of the Bureau

Budgeting

Planning

Preparation of Environmental

Statements

Bureau Cultural Resource Program

Cultural Resource Significance and

Evaluation

The Cultural Resource Specialist 
Public Involvement . . . . . . . .

Warden system

Bureau Contributions

Archeologists Contributions

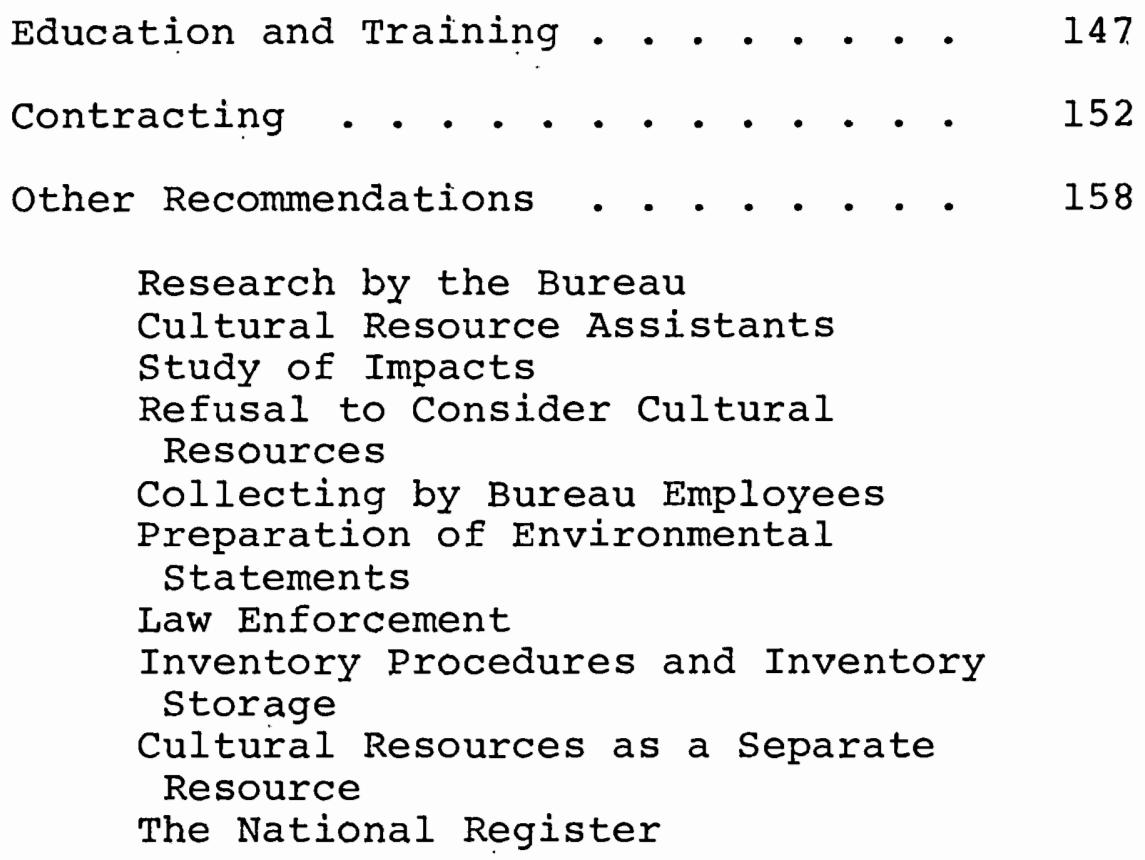

Research by the Bureau

Cultural Resource Assistants

Study of Impacts

Refusal to Consider Cultural

Resources

Collecting by Bureau Employees

Preparation of Environmental

Statements

Law Enforcement

Inventory Procedures and Inventory

Storage

Cultural Resources as a Separate Resource

The National Register 


\section{LIST OF. TABLES}

TABLE

PAGE

I Lands under the Exclusive Jurisdiction

of the Bureau of Land Management in

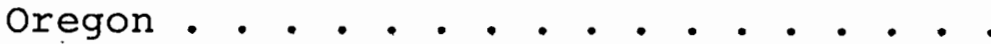




\section{CHAPTER I}

\section{INTRODUCTION}

The field of archeology has seen many changes in direction and emphasis in the past seventy years. These changes often have led to creation of new subdisciplines of archeological study. The fact that these changes have taken place is a sign of the field's vitality and ability to adapt to new methods, times, or needs. The most recent and ongoing change in the field is the study and development of cultural resource management. It is likely that a new subdiscipline will evolve in this area of concern. This thesis is not an attempt to deal with the concept of the development of a subdiscipline of archeology, rather it deals with the programmatic involvement of the Bureau of Land Management, United States Department of the Interior, hereinafter referred to as Bureau, in the management of Oregon's cultural resources. It is an attempt to fill the void in existing literature which in the author's opinion deals with how to do archeological research more than it deals with the how and why of cultural resource management. The audience for this thesis is principally the archeologist and the Bureau land use manager. 
The concept for this thesis was developed in 19.75 while the author was working as a Portland State University graduate student in archeology on federal lands in eastern Oregon. During this time, it became apparent that while changes were being made in the way in which agencies, such as the Bureau, managed archeological (as well as historical and social-cultural) resources, more were needed. Changes also were needed in the way in which archeologists dealt with the various agencies and with each other. Changes were drastically. needed in the way in which both the agencies and the archeologists dealt, or failed to deal, with the general public, both those interested in archeology and those who were apathetic toward the resource.

In March of 1975, the author was hired as District Archeologist for the Bureau's Lakeview District in southcentral Oregon. The last three years have been spent actively working in the field of what has come to be known as cultural resource management (even though many archeologists refuse to accept this term) and developing a cultural resource management program for the Lakeview District. The experiences of these three years have formed the basis of this thesis. Any opinions expressed are those of the author, not of the Bureau or of other Bureau employees unless so stated and cited.

The importance of consideration of the Bureau's cultural resource management program lies in the Bureau's 
makeup. First, the Bureau is clearly involved in management of Oregon's cultural resources. The mandates of federal legislation, spanning some 70 years, require the Bureau to manage the resource and so it has actively begun the task of building a cultural resource management program. Secondly, some 52 per cent of the state of oregon is federally administered lands. The Bureau controls $15,724,455$ acres in Oregon (U.S. Department of the Interior, Bureau of Land Management 1978a:4). These lands are comprised of 2.6 million acres of timber lands, known as the $O \& C$ lands, located west of the Cascades, the principal river basins of the Plateau, and a large portion of the eastern part of the state. In addition, the Oregon state Office of the Bureau administers 310,239 acres scattered throughout the state of Washington (U.S. Department of the Interior, Bureau of Land Management 1978a:4).

Thirdly, the Bureau has become one of the major supporters of archeological survey and inventory work in the state. Since 1975, a sizeable amount of funding has been provided in oregon for survey work. The potential for increase in the future is tremendous.

Fourth, the Bureau has an obligation to the public to manage this resource in the best interest of the general public.

The thesis is an attempt to explain cultural resource management, including the concept as perceived by the 
Bureau, its development, and its legal basis. The thesis includes a discussion to clarify why archeology is not the same as cultural resource management as it appears the distinction must be made. The thesis is further an analysis of the Bureau's cultural resource management program and its effect on the archeologist and other professionals, ethnic groups, the general public, and other state and federal agencies.

In the analysis of the Bureau's cultural resource management program, a number of subject areas evolve where the author feels problems exist. These are:

(1) Expansion of cultural resource protection through law enforcement.

(2) Inability to adequately analyze impacts to cultural resources during preparation of environmental statements.

(3) Program organization which does not allow research by Bureau employees.

(4) The lack of training of District cultural resource specialists in all aspects of cultural resources.

(5) Lack of a degree program in cultural resource management at the universities.

(6) Need for public involvement and participation in cultural resource management.

(7) Completion of contract work which is on time, addresses all aspects of cultural resources, provides 
meaningful development of site significance evaluations, and provides worthwhile management recommendations.

(8) Complexity of the National Register nomination procedure for sites of significance.

(9) Reorganization of the Bureau's program to identify cultural resources as a separate resource from other programs.

(10) Inventory procedures and storage of inventory data.

(11) Failure or refusal to consider the preservation or protection of cultural resources.

The remainder of the thesis addresses these subject areas and suggests ways in which the author feels a better cultural resource management program in oregon can be developed. It is hoped that by providing a copy of this thesis to the Bureau and universities these problems and solutions might be addressed. 
CHAPTER II

\section{A REVIEW OF CULTURAL RESOURCE MANAGEMENT}

Today the terms cultural resources and cultural resource management are used frequently by archeologists, federal agencies, and others. Yet, it is apparent that they do not share the same meanings for these terms. One of the purposes of this thesis is to examine the meanings assigned to these terms by archeologists and the Bureau so that problems in communication can be addressed and recommendations for resolving them presented. In order to accomplish this, an examination of the development of cultural resource management and its properties is necessary

While in the dictionary sense, there is no definition of cultural resource management, each word as a component can be defined. The meaning of these words are helpful in understanding the definitions of cultural resources and cultural resource management which have been developed by the Bureau.

Cultural is defined as "of or relating to culture" (Morris 1969:321). Culture was defined in 1871 by Edward B. Tyler as "that complex whole which includes knowledge, belief, art, morals, custom and other capabilities and 
habits acquired by man as a member of society (1871: Reprinted 1955)." (Clifton 1968:5).

Resource is defined as "an available supply that can be drawn upon when needed" (Morris 1969:1107). There is an underlying implication that resources will be eventually used. Supply is the existing inventory of cultural resource sites.

Management is defined as "the act, manner or practice of managing, handling, or controlling something" (Morris 1969:792). It implies order, that someone is in control and that things will happen according to a set plan.

These concepts are reflected in the definitions developed by the Bureau for cultural resources and cultural resource management. Cultural resources are

those fragile and nonrenewable remains of human activity, occupation, or endeavor, reflected in districts, sites, structures, buildings, objects, artifacts, ruins, works of art, architecturt, and natural features, that were of importance in human events. These resources consist of (1) physical remains, (2) areas where significant human events occurred -- even though evidence of the event no longer remains, and (3) the environment immediately surrounding the actual resource. Cultural resources, including both prehistoric and historic remains, represent a part of the continuum of events from the earliest evidence of man to the present day (U.S. Department of the Interior, Bureau of Land Management 1978b:2).

Cultural resources include the full realm of culture, past, present, and future. Archeological resources are only a part of the total comprising cultural resources. 
Cultural resource management is

the development and implementation of programs designed to inventory, evaluate, protect, preserve, and/or make beneficial use of cultural resources (including evidence of prehistoric, historic, and recent remains) and the natural resources that figured significantly in cultural systems. The objective of such programs is the conservation, preservation, and protection of cultural values through management, and the scientific study of these resources for the public good (U.S. Department of the Interior, Bureau of Land Management 1978b:3).

The concept of management is essential to the understanding of the Bureau's definition. The Bureau is a multiple resource management agency. This means simply that upon those public lands for which it has responsibility, the Bureau must identify the resources present and develop a means by which they can be used which will best benefit the public.

These definitions set the parameters within which the Bureau deals with archeological sites and archeologists. The Bureau is clearly concerned with more than just archeological sites in its cultural resource management program.

Archeologists, on the other hand, have traditionally been concerned with archeological sites. Most often these have been the physical remains of prehistoric cultures. Historical sites, especially structures, were the realm of historians and a few historic archeologists. Ethnography was the duty of social-cultural anthropologists and of interest only if it could illuminate past lifeways. 
The interaction between archeologists and the Bureau has frequently been based upon these differences of outlook. In many cases, the Bureau has been (or should have been) discussing cultural resources while the archeologists heard archeological sites.

A brief review of the development of cultural resource management is necessary to understand how the current relationship between archeologists and the Bureau developed. It is also necessary to understand why the Bureau is involved in cultural resource management.

THE LEGAL BASIS FOR CULTURAL RESOURCE MANAGEMENT

The basis for the Bureau's involvement in cultural resource management is contained in the numerous federal laws which have been enacted by Congress over more than 70 years that deal with the archeological, historical, and other cultural values which have come to be known as cultural resources. While these laws have been reviewed and discussed in some detail by various authors to date (Lee 1970, McGimsey 1972, Hallinan 1973, Hester et al. 1973, Scovill 1974, Green 1975, Reaves 1976, King et al. 1977, Moratto et al. 1977, Schiffer and Gumerman 1977), a further review is germane to the thesis. In addition, there is legislation and regulations pertaining to the Bureau and affecting cultural resources which have not been reviewed. 
It is strongly recommended that the serious student of cultural resource management, the cultural resource contractor, and the land use manager be familiar with the laws and regulations in detail. The decisions which must be made as an employee of the Bureau or as a contractor must meet the standards, ethics, and mandates of these laws. Complete understanding of these laws is essential.

\section{Antiquities Act}

The federal Antiquities Act was the first major attempt of the federal government to provide a system of protection for objects or places of antiquity located on public lands. The law was passed at the urging of numerous archeologists and parties interested in antiquities who feared the total destruction of important archeological sites by collectors (Lee 1970).

The law set three precedents. (1) Recognition that the federal government was responsible for the r reservation and protection of antiquities on public lands. (2) Recognition of the need to protect and preserve historic sites and natural areas as well as archeological sites.

(3) Recognition that the Congress can and will respond to the voices of concerned citizens.

The law made it illegal to

- - appropriate, excavate, injure, or destroy any historic or prehistoric ruin or monument, or any object of antiquity, situated on lands owned or controlled by the Government of the United States without the permission of the Secretary 
of the Department having jurisdiction over the lands on which said antiquities are situated (16 USC 431-433).

The law took steps to regulate research use of the resource by creating a system of issuing permits for scientific examination. This system is essentially intact today .

The law further allowed the President to create national monuments by public proclamation.

The passage of the Antiquities Act provided the first means of management for archeological, historical, and natural resources by the federal government. While the law has had a varied amount of success in protection of the resources from collectors (Grayson 1976, Green and Collins 1978), it remains the primary law for prevention and prosecution of unauthorized destruction of sites. It remains the main control on archeological research and method of granting research privileges.

Mineral Leasing Act of 1920

This law provides for federal disposition of the minerals on public lands by leasing. The Secretary of the Interior can require special stipulations be placed on mineral permits and leases issued under the law to protect the environment and other land values including cultural resources. Stipulations can also be placed to require that the lessee bear the costs of compliance with cultural resource protection. 
Historic Sites Act of 1935

Chronologically, the next major piece of federal legislation to deal with cultural resources was the Historic Sites Act of 1935. The purpose of the law is stated to be "An Act To Provide for the Preservation of Historic American Sites, Buildings, Objects, and Antiquities of National Significance, and for other purposes" (16 USC 461).

The law states national policy in regard to preservation "to preserve for public use historic sites, buildings and objects of national. significance for the inspiration and benefit of the people of the United States" (16 USC 46I).

The law furthered the precedents established by the Antiquities Act of 1906 and set new ones. It declared that preservation of cultural resources is in the public interest and should be done for the benefit of the public. It uses the concept of significance as a criteria for preservation. To accomplish its intent, the law sanctioned the National Park Service, Department of the Interior, the authority to preserve data, make inventory surveys and investigations, acquire property, enter into agreements with states and others, restore or preserve properties and provide education to the public about the properties of significance (16 USC 462).

The law signaled the first effort on the part of the 
federal government to create a means to provide for the inventory and preservation of the resources that it was frequently destroying or allowing to be destroyed.

This provision, which led to the initiation of the National Park Service's activities in cultural resource management, facilitated development of the Interagency Archaeological Salvage program in response to the largescale, federal water-control programs that followed the close of World War II (Reaves 1976:19). Needless to say, this Act signaled the beginning of active federal involvement in specific archaeological investigations. An important outgrowth of this Act was the belated recognition that the federal government had a responsibility to alleviate partially the disastrous impacts that it regularly inflicted on cultural resources. In effect, the federal government had taken the first step towards acknowledging that its own destructive actions were not exempt from the provisions of the Antiquities Act of 1906 (Schiffer and Gumerman 1977:4).

National Trust for Historic Preservation Act of 1948

The Historic Sites Act was strengthened in 1948 with passage of the National Trust for Historic Preservation Act. Reaves states that the law was

passed to further the policies of the Historic sites Act. The Act was the first evidence of reawakening interest in the preservation of cultural resources. This awakening was stimulated by the alarming rate of destruction of such resources caused by renewed development activity following World War II (1976:19).

The potential for drastic impacts to cultural resources in the forthcoming era of development had not been lost on the archeological community.

In 1945, the Committee for the Recovery of Archaeological Remains was formed under the joint sponsorship of the American Anthropological Association, the Society for American Archaeology, 
and the American Council of Learned Societies (Reaves 1976:15).

The purpose of the committee was to advise the federal government in development of a sound program of salvage work (Reaves 1976:15). The Committee furthered the involvement of archeologists with the planning process in federal government programs. The involvement, however, was one of resource use rather than preservation.

Federal Aid Highway Acts of 1956 and 1958

The continuing development of the nation led to passage of the Federal Aid Highway Act of 1956 and its replacement, the Federal Aid Highway Act of 1958. These laws sought to remedy, through salvage, the damage to cultural resources caused by construction of the nation's highway system by providing the funds to recover (salvage) cultural resources in the path of construction (Reaves 1976:19). The legislation

took a step to further the concept of federal responsibility for mitigating adverse impacts, at least inasmuch as they occurred during the highway construction . . . Like the earlier salvage efforts, it did have the beneficial result of forcing archaeologists to become acquainted firsthand with the entire range of cultural resources in an affected area, not just the large, early, or deeply stratified sites (Schiffer and Gumerman $1977: 4-5)$.

The importance of this legislation should not be overlooked. Recognition of the need for developing regional frameworks for incorporation of salvage work evolved as well as addressing the problem of site 
significance in relation to government projects.

Reservoir Salvage Act of 1960

The next major piece of federal legislation regarding cultural resources was the Reservoir Salvage Act of 1960.

In response to the salvage efforts being carried out in the river basins and the tenuous funding that suffered their existence, a lobby began for more permanent and more adequate funding for the river basin salvage program. The Reservoir Salvage Act of 1960 (74 stat. 220) was the result. This act provided that the secretary of the Interior could, with special appropriated funds, provide for the recovery of historical and archaeological data that might be lost as the result of the construction of a reservoir or dam and its attendant facilities and activities. The Reservoir Salvage Act was never fully funded and many resources which came within its purview were lost because the funds were inadequate to meet the needs (Reaves 1976:19.).

While the law failed in many ways to eliminate the problems of adequate funding for salvage work on reservoir projects, it signaled another major step in the development of government involvement in cultural resources by providing a means of providing funds specifically for the recovery of cultural resources.

National Historic Preservation Act of 1966 and Department of Transportation Act of 1966

During 1966 with passage of the National Historic

Preservation Act (NHPA) and the Department of Transportation Act, the concept of conservation was introduced into

federal government programs (Reaves 1976:20). NHPA reinforced and updated the policy of national historic preservation which had been initiated with the 
Historic Sites Act of 1935. The importance of this law has been its impact in the way in which federal agencies approach the management of cultural resources. The law

placed additional leadership and coordinating responsibility with the Secretary of the Interior and directed that he expand and maintain a National Register of Historic Places. It created the President's Advisory Council on Historic Preservation and in section 106 of the Act, granted it a commenting and review function whenever properties on the National Register of Historic Places were to be affected by Federal actions (Reaves $1976: 19-20$ ).

The National Register, although it is often misunderstood, has developed as an important part of the management of cultural resources by federal agencies. For the first time under the conditions of section 106 of the law, an outside party was given an opportunity to comment on the effects which federal agency actions have on cultural resources.

The law removes archeologists from the role of subsequent laborers used to clear the way for ccnstruction to participants in the actual planning process prior to construction. Archeologists were required to adapt from a strictly academic role to one of planning, a role not yet fully filled today.

The law requires that the potential effects of a project upon any cultural resource be examined before the project takes place. If an inventory has not been completed, it requires the agency to determine if any resources are present and make an evaluation of that 
resource. For the first time, the size of a project is not the deciding factor for whether or not a survey. is completed.

The Department of Transportation Act requires the Department of Transportation to consider alternatives to destruction of a historic property before it undertakes construction projects. "Not only did the law require that alternatives be examined, but that all possible planning be accomplished to minimize harm" (Reaves 1976:20) .

Intergovernmental Cooperation Act of 1968

This law was passed to insure that there is a coordination of activities and cooperation between the federal government and all other levels of government. To implement this law, the Office of Management and Budget (OMB) in 1976 created the A-95 clearinghouse process. The OMB requested each state designate a single contact point for the federal government which could be notified of pending federal undertakings. This contact agency has become known as the state clearinghouse. When an important undertaking with environmental, social, or economic impacts is proposed by a federal agency, a notice is to be sent to the state clearinghouse for review and comment. The state clearinghouse is responsible to notify the proper state and local agencies of the proposed undertaking, assemble review comments, and return these to the federal agency sponsoring the proposed undertaking. The federal agency 
is required to address any comments and return a written narrative to the state clearinghouse responding to the concerns raised in the review process.

The importance of the A-95 clearinghouse process is its assurance in providing other governmental agencies the opportunity to review the evaluation of impact to cultural resources made by the Bureau.

National Environmental Policy Act of 1969

A growing concern evolved in the nation in the $1960 \mathrm{~s}$ that unnecessary and potentially harmful damage was being wrought upon the environment of the nation. The culmination of this concern for the cultural resource preservationists was passage of the National Environmental Policy Act of 1969 (NEPA). Reaves feels that "If one law had to be chosen as having had the greatest impact on the federal agencies, it would without any doubt be the National Environmental Policy Act of 1969" (1976:20).

Reaves' interpretation of the law is that

it is national policy to 'use all practical means . . to improve and coordinate Federal plans, function, programs, and resources to the end that the Nation may . . preserve important historical, cultural, and natural aspects of our national heritage . .' Cultural resources are also a part of the scope of environmental concerns.

The National Environmental Policy Act further directs agencies in their planning activities to develop a statement setting forth: (1) the environmental impact of the proposal, (2) adverse effects that are unavoidable if the proposal is implemented, (3) alternatives to the proposal, (4) the relationship between local short-term uses 
and the maintenance and enhancement of long-term productivity, and (5) irretrievable and irreversible commitment of resources involved in the proposal. Loss of cultural resources is at very least an irreversible, irretrievable commitment of those resources (Reaves 1976:20-21).

NEPA set specific requirements that the federal agencies determine and evaluate the impact of their undertakings on cultural resources. In order to determine impacts, the agency is required to first inventory the resource. Impacts are to be mitigated to the fullest extent possible. Mitigation has become a key concept in cultural resource management. It pertains to alleviating or moderating the extent of destruction. The land use manager is required to consider alternatives to complete destruction by salvage. The conservation archeologist is thus given a powerful tool to lessen the destruction of the resource base. It must be remembered, however, that NEPA will benefit cultural resources only if an environmental statement is prepared.

Geothermal Steam Act of 1970

This law authorizes the Secretary of the Interior to issue leases for the development of geothermal energy on federal lands. The implementing regulations allow the secretary of the Interior to require protection of the environment. Special stipulations can be required for protection of cultural resources and the lessee can be required to bear the costs of compliance with these stipulations. 
Presidential Executive order 11593

In the early 1970s parts of a cultural resource management program were available and the stage was set for federal agencies to develop an organized cultural resource management program. A catalyst was needed to bring together the various parts (Reaves 1976:21). This was accomplished by the issuance of Presidential Executive Order 11593 on May 13, 1971. Reaves notes that the order provided three needed mandates to federal agencies. Agencies were directed to:

(1) administer cultural resources in agency control in a spirit of stewardship and trusteeship for the future (that is, get in the cultural resources management business), (2) conduct agency operations to maintain, restore, and preserve cultural resources on Federal land, and (3) conduct agency operations in such a way, in consultation with the President's Advisory Council on Historic Preservation, to assure that agency plans contribute to preservation of nonFederal cultural resources (Reaves 1976:21).

The order directed the agencies to inventory all cultural resources on the lands they controlled and nominate suitable sites to the National Register as required by NHPA. While the deadline for completion of this task, July 1, 1973, was unrealistic given the expanse of public lands in the nation, the Executive order in effect put the federal agencies in the cultural resource management business.

Agencies which previously had ignored or only halfheartedly considered cultural resources under the previous laws could no longer do so. Threat of a lawsuit, 
particularly under the stipulations of NEPA; combined with the Executive ordex encouraged agency involvement in management of cultural resources.

Archeological and Historic Preservation Act of 1974

While the potential for a cultural resource management program was set by 1974, the necessary funding for major undertakings had not been addressed. While laws such as the National Environmental Policy Act and the National Historic Preservation Act and Executive Order 11593 require consideration of cultural resources, they are only enabling legislation and mandates which provide no specific funding to accomplish their purposes. The efforts of archeologists over several years' time succeeded in the passage of the Archeological and Historic Preservation Act (AHPA) in 1974.

AHPA provides a means by which a major federal undertaking can be funded for cultural resource work without having to have special appropriations. While this is of major importance for the largescale picture, it does not address the problem of funding the day-to-day projects of an agency. The various agencies still must seek special funding for hiring cultural resource personnel and for contracting of cultural resource work on non-major projects and of general inventory work to meet the commitments of Executive Order 11593. The AHPA is by no means a cure-azz for funding. 
Federal Land Policy Management Act of 1976

The Federal Land Policy Management Act (FLPMA) was designed to provide the Bureau with new and better management authority for the lands under its administration. The mandates of this law have yet to be fully implemented, but have many items of importance to cultural resource management.

FLPMA states that

The national interest will be best realized if the public lands and their resources are periodically and systematically inventoried and their present and future use is projected through a land use planning process (Section $102(a)(2)$ ).

This Section of the law clearly directs the Bureau to determine what cultural resources are present on public lands. Once an inventory has been accomplished, the Bureau must develop, with public input, a use plan for the resource.

The law further states that

the public lands be managed in a manner that will protect the quality of scientific, scenic, historical, ecological, environmental, air and atmospheric, water. resources, and archeological values (Section $102(a)(8)$ ).

This Section of the law emphasizes the responsiblity of the federal government to protect the cultural resources under its jursidiction.

The law gives the Bureau a means by which it can potentially protect cultural resources. Section 303 (a) provides a penalty for violation of any regulation pertaining to the protection of cultural resources on Bureau 
administered lands,

- . any person who knowingly and willfully violate any such regulation which is lawfully issued pursuant to this Act shall be fined no more than $\$ 1,000$ or imprisoned no more than 12 months, or both.

The law also allows the Bureau to contract law enforcement services with local law enforcement agencies or to develop its own capability for law enforcement. While this provision has not been implemented in all of the Bureau's Districts in Oregon, its potential value for cultural resource protection is obvious.

The law provides an additional means of protection for cultural resources within their environment. The law states that areas of critical environmental concern (ACEC) are to be protected. Cultural resources are specifically mentioned as being possible ACECs. If an area has high cultural resource values which may be threatened by other uses or natural forces, the area can be designated as an ACEC and the Bureau must develop special planning to provide for its preservation and protection.

Code of Federal Regulations

Specific regulations have been created to provide interpretation of legislative intent and to provide a means by which legislation can be implemented by a federal agency. These regulations are codified in the code of Federal Regulations. The following regulations are of 
specific concern to cultural resource management.

36 CFR 60: National Register of Historic Places -

Criteria for Statewide Historic Surveys and Plans. Under the auspices of Section 106 of the National Historic Preservation Act and Section (2b) of Executive order 11593, a determination of eligiblity may be requested of the Secretary of the Interior. This regulation provides the framework for providing the necessary information to make such a determination.

36 CFR 64: Establishes the Criteria and Procedures for the Identification of Historic Properties. Executive order 11593 directed agencies to inventory sites on public lands to identify those sites which qualified for National Register listing under the National Historic Preservation Act. These guidelines assist an agency in the completion of an inventory.

36 CFR 65: Recovery of Scientific, Prehistoric, Historic, and Archeological Data - Procedures for Coordination and Notification. The Archeological and Historic Preservation Act provides for the recovery of cultural resources impacted by major federal undertakings. These guidelines establish the procedures and the obligations of the various parties and the federal agencies in regard to the law.

36 CFR 800: Protection of Historical and Cultural Properties. $36 \mathrm{CFR} 800$ implements the mandates of section 
106 of the National Historic Preservation Act of 1966 and Executive Order 11593, Protection and Enhancement of the Cultural Environment.

These regulations outline the duties and operation of the Advisory Councit on Historic Preservation, the responsibilities of the federal agency, and the state historic preservation offices.

\section{ARCHEOLOGISTS AND CULTURAL RESOURCE MANAGEMENT}

The previously described laws, Executive order, and regulations form the basis of the Bureau's cultural resource management program: The program today is a complex approach to meet the needs of diverse interests: archeologists, historic preservationists, ethnic groups, architects, sociologists, social anthropologists, environmentalists, and naturalists. While archeologists have supported and fought for passage of legislation, they generally have not taken an integrated approach to the creation of the resulting cultural resource management program. It has been noted that in the early part of the century, archeologists worked closely with the historic preservation movement (King et al. 1977, King and Lyneis 1978). This association lapsed during the post World War II period, but was renewed with the passage of the National Historic Preservation Act in 1966. Since 1966, archeologists have begun, some with great reluctance, to form a 
multi-discipline approach to the cultural resource management needs of the federal government. Several approaches have been devised and discussed by archeologists to address cultural resource management, none of which adequately address the concept as perceived by the Bureau. Before the more recent approaches to cultural resource management are examined, it is necessary to take a look at the most common form of cultural resource management prior to 1966 - salvage.

\section{Salvage Archeology}

The relationship of archeologists toward government agencies for much of the period from passage of the 1906 Antiquities Act until the passage of the National Historic Preservation Act of 1966 was passive. The bulk of the enabling legislation was directed towards the removal of sites rather than in situ preservation. Archeologists provided goods and services, sometimes below cost, to agencies which specified the type of work, place of work, and its scope.

The management of archeological resources during this period was destructive in nature. Sites in the way of projects were merely to be removed so that the project could continue. Because the federal government was responsible for much of the site disturbance in construction of dams, highways, land reclamation projects, it took some responsibility to salvage these disturbed sites. Much 
of the archeology done during this period was designed, if designed at all, to save what could be saved before the waters raised or the bulldozer passed over. In many areas only the biggest or best sites were examined. Many times only limited testing could be performed, leaving much work undone. In nearly every case, time was limited and the funding levels inadequate. The results of many such activities are still not fully reported today because the money went to recovering as much as possible rather than site reports.

During this same period, thousands of sites were destroyed by artifact collectors. The increase in population, urban growth, new roads and highways, increase of free time, the travel trailer and four wheel drive all combined to place thousands of persons into the field seeking curios of the past. The federal agencies during this time did virtually nothing to stop the collectors. In many cases, federal employees were the collectors.

The rate of land disturbance combined with the activities of artifact collectors created a picture so bleak by the end of the 1960s that Hester Davis asked "Is there a future for the past" (1971), a question asked by the symposium held to discuss the status of archeological resources in the face of rapid destruction.

The work of the salvage era was more of a reaction than a plan. Little emphasis was put on preservation of 
sites, use of research results, design of projects, adequate funding, and allowing proper time for the completion of the necessary work.

By the late 1960s and early 1970s, the picture had begun to change. The environmental movement was taking effect with passage of the National Environmental Protection Act. Cultural resources were given additional protection under the National Historic Preservation Act. The President acted to bring about an integrated program specifically aimed at the proper care and management of cultural resources.

Federal agencies such as the Bureau were required to determine the effects of their actions upon the environment, including cultural resources, and to justify them. The effects had to be reduced or corrected as much as possible. (It should also be remembered that effects can be beneficial in nature rather than destructive.)

Consideration had to be given to preservation as an alternative to destruction. The public had to be asked if they had any special interest or concerns.

A program of preservation began to develop as a means of management of cultural resources. Salvage ceased to be the principal form of management action taken by agencies. Today, salvage is considered to be a negative approach to cultural resource management, something that should be done as a last resort if all else fails. The 
term produces visions of destruction, sloppy work, work left incomplete, lack of research use of data.

Salvage archeology is still a necessary part of American archeology. Salvage will frequently be required and at times will be the best form of management. It is a tool which can properly be used in cultural resource management.

Salvage is not, however, the same thing as cultural resource management. First, it is mainly a concern of the archeologist (although historians will often move structures, in effect, salvage them). Its approach is destructive rather than protective. It leaves out any opportunity for future use of in situ sites. If used as an ethic, it places the value of cultural resources second to all others.

Contract Archeology

The early 1970s saw a rapid growth in fedtrally funded contracts for archeological work as an attempt to fulfill the requirements of various legislation. Lacking staff to complete the work, federal agencies contracted for the necessary services. Thus, contract archeology has evolved to provide these services to enable federal agencies to comply with legislated mandates.

The basic problem with contract archeology as an approach to cultural resource management is in its perspective. The term itself implies a limitation of the 
work to be done to archeology. Contract work completed to date may meet the requirements of archeology, but seldom requirements of other aspects of cultural resource management. The term contract archeology would be acceptable if the archeologist and the agency understood that archeology alone does not meet the legal requirements of cultural resource management and the contract and report acknowledges the need for other work. The term is not, however, synonymous with cultural resource management. Rather, contract archeology is merely another tool of cultural resource management.

\section{Conservation Archeology}

Conservation archeology is a term frequently seen in the literature (King n.d., Schiffer and Gumerman 1977). The term was developed by William Lipe in a paper entitled A Conservation Model for American Archeology (1974). Lipe does not argue for a program of managing cultural resources but rather for the management of archeological resources. He argues for the conservation of archeological remains by the archeologist becoming involved in the management of the resource (1974:223). Conservation archeology calls for archeologists to direct themselves to positive measures of conservation of sites (Lipe 1974:226). This approach is limited in the type of use which can properly be made of cultural resources. It tends to specifically rule out consumptive types of uses. 
Besides its limited approach to the use of archeological resources, conservation archeology does not fulfill the needs of the Bureau in cultural resource management. Conservation of the nation's archeological resources is only one aspect of cultural resource management. The Bureau's cultural resource management program includes the preservation, protection, and public use in research of cultural resources, as well as conservation (U.S. Department of the Interior, Bureau of Land Management $1978 \mathrm{~b}: 3)$.

Public Archeology

Another term frequently used by archeologists is public archeology. The term was recognized and developed by Charles McGimsey in his book Public Archeology (1972). McGimsey defined public archeology as a statement of principle.

There is no such thing as 'private archeo:ogy.' We are none of us born in a vacuum. We are all products and recipients of tens of thousands of years of biological and cultural history. This history, working with our present-day surroundings, affects our every thought, our every action. Knowledge of past, just as knowledge about our environment, is essential to our survival, and the right to that knowledge is and must be considered a human birthright. Archeology, the recovery and study of the past, thus is a proper concern of everyone. It follows that no individual may act in a manner such that the public right to knowledge of the past is unduly endangered or destroyed (1972:5).

McGimsey details the way in which the public should or can be involved in archeology. The duty to involve 
them was placed on the archeologist, the federal government, and state government.

Thomas king later refined the term public archeology to refer to "the conduct of archeology, broadly defined, in the public interest, in congruence with public law and policy and in some cases using public funds" (King n.d.:2). Public archeology thus can have two general meanings: involvement of the public with archeology directly or archeology performed on behalf of the public.

The problem with public archeology as a suitable term to describe cultural resource management is that it is limited to archeology. For some this is exactly the reason the term is chosen over cultural resource management. Thomas King feels the term cultural resource management to be a "somewhat presumptuous title for archaeologists to take up as their own" (King n.d.:3). He further states

There are many kinds of cultural resources that are not particularly archaeological, or at least whose management requires operations and expertise that go far beyond anything an archaeologist is likely to do, need or acquire (King n.d.:3).

The term cultural resource management was not created by archeologists but created by the legislation pertaining to the resources of archeology, history, ethnic group land uses, and architecture. The concepts of the legislation produced the name. These resources are best described as being parts of culture and as resources to be used, and managed by a federal agency. 
Historic Preservation

The concept of historic preservation is an attempt to bring archeology more in line with the legislation and to integrate historical, architectural, ethnic, and other resources under one programmatic approach (King et al. 1977: $1-2)$.

Historic properties can be defined as

A historic property, to us, is any place where people have created something that can contribute through its continued availability for individual or group experience - to our "consultable record" of human existence (King et al. 1977:5).

This definition fits all of the criteria for the Bureau definition of cultural resources: it considers anthropology as the basic premise for the work, the resources include archeological, historical, and other cultural sites, the reasons for preservation is for research and public use. When compared to the Bureau's definition of cultural resources; the term is acceptable as a synonym, however, there has not been a demonstrated need for such a term and it does not properly address management. It appears archeologists distrust the terminology devised by government and have a hard time accepting the philosophy of cultural and management.

The goals of cultural resource management as presented by the Bureau have not and can not be met with the outlook of salvage archeology, public archeology, contract archeology, or conservation archeology. These 
are merely parts of cultural resource management. The underlying problem with the aforementioned concepts is that none properly address the concept of management. The resultant work of archeologists under these concepts does not address the Bureau's needs as

there is little emphasis on planning, conflict resolution, proposal preparation, budgeting, or other day to day activities of conservation archeologists (or historic preservationists) who work closely with the Federal system, or within it (Wildesen, in press, p. 12).

There is also a counterproductive trend when each party uses different terms or approaches to a single problem. Use of the same language and meanings is essential to a common understanding. 


\section{CHAPTER III}

\section{THE PRINCIPAL PARTIES}

The management of cultural resources brings the Bureau into contact with a number of different parties. An understanding of the interaction of the Bureau with these parties is necessary for an understanding of the Bureau's cultural resource management program.

\section{THE NON-FEDERAL ARCHEOLOGIST}

There are 42 institutions of higher learning in oregon. Thirteen are community colleges, 21 are independent colleges, and 8 are in the state system. Most of these institutions offer, or have offered, course work in archeology. However, only the major state universities with Bachelor, Masters, and/or Doctoral programs have developed degree programs in anthropology or archeology. The major State universities represent the most frequent contact which the Bureau in Oregon has with archeology. These contacts can take various forms. (1) They have provided five of the Bureau's current cultural resource personnel in oregon. (2) They are a prime source of contract services. (3) They may educate future Bureau employees in the field of cultural resource 
management. (4) They can affect Bureau programs through participation in planning. (5) They are the central repository for data and inventory storage. Each form of contact has specific problems in how the Bureau and the universities perceive the needs and goals of cultural resources and each other's responsibilities and motives.

\section{Contracting}

Contracting is the most frequent type of contact and source of conflict between the universities and the Bureau .

The bulk of past archeological contract work has been done by Oregon universities or persons trained in Oregon. Oregon archeologists feel that this is exactly as it should be. There is a feeling of territoriality among archeologists and an unwritten code that one will not work in another state (or another archeologist's area) without first contacting local archeologists to lind out if they intend to do the work. It is their opinion that only someone intimately familiar with the area should be given contract work in that area (Wildesen 1979:8). In a way, this is a principle of merit, one addressed specifically as an evaluation factor in determining a contractor's capability (Wildesen 1979:8-9). However, this should not be a limiting factor on awarding contracts. The capability exists for someone outside oregon to complete all the necessary tasks for contracting in 
oregon. In addition, the growing number of qualified independent contractors has begun to erode the base of territoriality.

Choice and availability should create better contract research due to sharper proposals, better management recommendations, and wider experiences of the contractors (Wildesen 1979:11).

Each institution of higher learning in Oregon, excluding the three major state universities which were known to do such work, was questioned by letter if they had provided or would provide contract archeological services. Only Southwestern Oregon, Eastern Oregon State College, Lewis and Clark College, Southern Oregon State College answered yes. Combined with the three major state universities, there is a limited number of potential contract personnel within the state.

What are the contract capabilities of these institutions? The Airlie House Seminar participants (McGimsey and Davis 1977) discussed the skills, resources, and infrastructure necessary to do quality cultural resource contract work. Basically, the requirements for good contract archeology are that the university have the necessary administrative capability for processing of contracts, payrolls, budgets, overhead costs, etc. and can provide general services. They must have staff qualified to do the work specified in the contract, to design project 
work, and report writing capability. They must have the necessary facilities such as laboratory and field equipment. They must have the capability to curate materials collected on a permanent basis (McGimsey and Davis 1977: 54-58). In reviewing these requirements; only the three major state universities appear capable of the full range of contract work. The programs at Southwestern Oregon, Eastern Oregon State College, Lewis and Clark College, and Southern oregon state College generally consist of one or two faculty members. These institutions would be most capable of short, nonintensive, small surveys (which do not require excavation) and literature search reports. A major contribution of these institutions to cultural resource management is in the realm of public awareness and education. They are excellent contact points for smaller communities geographically separated from the major universities.

The three major state universities have the most capability of providing goods and services to the federal agencies and private industry. These universities have each developed as separate entities and each has developed a territoriality within the state.

The University of Oregon has the largest capability for contracting because of its size and past experience statewide, but particularly in eastern oregon and the Willamette Valley. It has provided a large percentage of 
the Bureau contract services to date in oregon. In addition to the Department of Anthropology, the Museum of Anthropology (formerly a part of the Museum of Natural History) also provides services. The Museum has been very active statewide in providing services to agencies such as the Bureau and the Oregon State Highway Department and private corporations which undertake projects on public lands. Oregon State University has most recently developed expertise on the Oregon Coast and has also done work in other parts of the state. Its capabilities, including work force, is somewhat smaller than that of the University of oregon. It has also developed a program in historical archeology and has conducted research and excavation at historic sites.

Similar to Oregon. State University, Portland State University has a more limited capability than the University of Oregon because of its size. Portland State University has developed its capabilities mostly in eastern Oregon and because of its location, the greater Portland metropolitan area. Portland State University has mainly been involved with small surveys, limited excavations, and literature reports.

One indication of increased consultation work on Bureau lands in Oregon, as well as Bureau lands in general, is the issuance of antiquities permits. Generally, two types of permits are issued: consultation and research. 
Consultation permits are generally limited in scope and allow only survey, surface collection, and limited test excavation. There were five consultation permits issued for Oregon in Fiscal Year 1978 and one research permit. The Bureau, nationwide, noted an increase of 33 per cent in the number of permits issued in Fiscal Year 1978. Consultation permits accounted for 87 per cent of the total permits issued, a 63 per cent increase over Fiscal Year 1977 (U.S. Department of the. Interior, Bureau of Land Management 1979a).

Increases of this magnitude clearly show the increase in consultation work and the decline of strictly research work. In addition, consultation permits are issued for a general area rather than one specific area in most cases. A permit for consultation might be used for several projects during its time.

Contract work in Oregon as elsewhere has led to a number of problems for the Bureau. The major problem is not usually one of doing adequate archeological work, but rather in doing archeological, historical, and other cultural resource management. There are additional problems of bidding, completion of work on time, and compliance with contract stipulations.

The contracts which the Bureau awards for cultural resource management work usually specify completion of more than just archeological work. They will usually call for 
development of a report on cultural resources. The completed reports for those contracts which are done solely by archeologists, specializing in prehistoric archeology, may only touch upon historic sites and records, if they do so at all. Other cultural sites, unless they have a unique history or feature, are usually completely overlooked. The problem stems from the archeologist not being sufficiently trained in historical site work and in anthropology. There is also a problem with the composition of contracts as written by the Bureau. If the contract was not specific enough in its stipulations, it would be unreasonable to expect anything extraordinary from the contractor.

The contractor, on the other hand, may have his own ideas as to what is required and fail to communicate with the Bureau to see if this is indeed what is being sought. There have been instances where contractors have requested that prework conferences (a standard part of most Bureau contracting to discuss and explain the conditions of the contract) be eliminated because they already knew what was required and how to do $i t$. These same contractors failed repeatedly to make formal progress reports during the course of a contract as required and had to be continually contacted by the District. In one instance, the contractor declined to be interested in information concerning environment, land use, Bureau procedures, when offered by the Bureau. The resultant report lacked one section re- 
quired, did not address Bureau needs in management, had erroneous data on the description of the environment, besides being late. Most of the deficiences could have been avoided through proper communication during the course of the contract.

There is also a general problem with contractors doing work for private parties involving Bureau lands. They do not seem to feel that they are required to make contact with, or to supply data to, the proper District office. This is far from the case. The granting of leases, rights-of-way, or special land use permits to another party does not remove the Bureau from monitoring for compliance with environmental protection and planning standards that would be required if the Bureau were undertaking the work (36 CFR 800.4).

Antiquities permits for such work in oregon on Bureau lands carry stipulations that the Bureau District Managers will be notified of pending work, that work must be based upon a proper research design, and that reports be furnished within 30 days of completion of the work. There have been repeated instances of contractors doing work on Bureau lands without notification. There have been repeated cases of antiquities permit reports being late, some as much as two years.

This type of attitude appears to mainly reflect contractors doing cultural resource management work in 
conjunction with universities. It is the author's experience that the private sector, those doing cultural resource management work for a profit, follow more fully and completely the conditions of contracts, meet contract deadlines, make proper notification, seek information and assistance from the Bureau, and provide a project report within the 30 day period (or explain the delay).

This situation could lead to serious repercussions for contractors. First, failure to make proper contacts, making errors which are obvious to people in the District, and failure to complete the work on time and still not provide any information to the District, will not improve the standing of contractors with land use managers.

Secondly, the Bureau's contracting department could bring pressure on the contractor by not allowing them to receive new contracts due to past failure to produce. There is also the possibility that the Bureau will request that the contractor's antiquities permit be revoked or denied because of failure to meet permit stipulations.

In the case of contractors working on private undertakings on Bureau lands, failing to produce the necessary information, the Bureau may have no recourse but to take actions against the organization for which the contractor is working such as denial of work permits. This may result in the loss of future contract work. There is also a problem with development of site 
significance and cultural resource management recommendations in contract reports.

The development of meaningful statements about site significance is a problem which has plagued archeologists. There have been many schemes devised for dealing with significance (e.g. Lipe 1974, Aikens 1976, King et al. 1977, McGimsey and Davis 1977, Schiffer and Gumerman 1977).

Proposals have been made to base significance on National Register eligibility, research value, cultural value, historical significance, ethnic significance, public significance, monetary significance (e.g. King et al. 1977, McMillan et al. 1977, Schiffer and Gumerman 1977).

The Bureau has not assumed a position of assessing site significance as such. Rather, the Bureau's evaluation system (See page 117) is directed at resource use allocation. However, in day-to-day actions, the Bureau resource specialist must either decide the relevant significance of a site or depend upon that evaluation in a contract.

One of the basic premises of cultural resource management work is that the sites identified to be disturbed, excavated, collected, etc., must be evaluated and decisions made about their future. It can be argued that all sites are significant. However, when time, money, public needs and good are considered, which sites are more significant? When these decisions are made, they must be justified (perhaps in a court of law) by the best and most 
current scientific needs and thought. If a particular site is said to be insignificant and not worthy of an agency's time and money, the contractor may be required to explain the evaluation. This will be true especially in large project areas where sites may range from small lithic scatters to deeply stratified villages. The natural tendency is to spend all the time and money on the spectacular or sites of special interest to the researcher to the neglect of other sites. This approach will not succeed in many contract situations today where the scope of work calls for examination of all site types. The obvious problem is, when has one type of site been sufficiently considered in a given research design? How many parts of a whole must be examined to be able to talk with reliability about that whole? The land use manager, with or without the aid of a cultural resource specialist, will be attempting to fulfill legal obligations which call for an examination and evaluation of all sites and site types. If contractors want to avoid a strict contract formula approach to contract work, they must be prepared to use a research approach which justifies its end and provides legal coverage to the land use manager.

The contractor in nearly all contract work must make management recommendations to the land use manager based upon their evaluation of significance of the cultural resources. Contractors appear to have been unable 
in the past to commit themselves to making recommendations which may lead to the destruction of a site. The types of recommendations which they have made in the past pertain mostly to archeological research. They have failed to provide enough detailed information about their recommendations to explain why that recommendation was made. For instance, they might recommend that a controlled surface collection be made of a site. They will typically not explain what is meant by a controlled surface collection, what it will cost, how long it will take, what research questions will be answered by making the collection, whether the site should not be collected, whether the site is of National Register quality, and whether it might become so later. These types of questions should be presented and analyzed in the recommendation section of the report by the contractor. Without such detailed information, the land use manager will not be: able to properly make a decision. The purpose of doing contract work is to obtain answers. The contractors are failing to provide the needed answers in their contract work.

It has been suggested that the making of management recommendations not be made a part of the contract. This would leave the District cultural resource specialist the task of making recommendations which can be used in preparation of management plans, site protection measures, etc. This has marked disadvantages. First, the person 
who has worked recently with compilation of the data should be the best choice for making recommendations. Time and money would be lost in having the cultural resource specialist become as familiar with the data.

Secondly, this removes the contractor from an important part of the decision making process which would place contractors in a passive, non-participant role. The principal job of the archeologists at the universities has traditionally been that of teaching, rather than research. While contract work has been an important part of university work and one justification for the archeology programs, it has not been the primary purpose of the faculty positions. Field work, whether for a grant or a contract, is most often undertaken between terms, during the summer, or while on leave from the university. Much of the actual contract work done by the universities is performed by students under the name of the faculty member who holds the actual contract or antiquities permit. Field schools have often been used in contract work and research in oregon.

The use of students and the training of students under contract work should be viewed with caution. It is very possible that the federal government could question the adequacy of the work if the named individual on the contract or antiquities permit does not directly supervise and take part in the field work and analysis. It is also 
questionable as to whether it is professionally ethical to use actual sites for teaching.

The basic content of most cultural resource reports is of interest only to archeologists. Ninety per cent of the content of most reports pertains to archeological research. This reflects a general attitude among archeologists doing contract work that good archeology must come from contract work. In nearly all publications discussing cultural resource management, the primary consideration is how to put archeological research first in completion of a contract. The problem is that archeologists are using cultural resource management contracts to do archeology rather than using contracts to perform cultural resource management which results in good archeology. Seldom does a contract produce or propose new and innovative ways to preserve and protect sites or determine impacts. It is small wonder that many land use managers feel they are paying a lot for very little.

The comments of the participants of the Airlie House seminars reflect this attitude among archeologists in describing the difference between cultural resource management reports and research.

A third difference is that a certain, generally quite small, proportion of an archeological management study must be devoted to relating the findings to factors unrelated to archeology or other aspects of science, e.g., analysis of the number of sites to be adversely affected by a particular earth moving project, establishment of archeological priorities relative to a spon- 
sor's planning goals. In a strictly scientific sense, these are side issues (McGimsey and Davis $19.77: 26-27$ ).

While the seminar participants recognize the importance of making management recommendations, there is still an emphasis toward archeology rather than cultural resource management.

The seminar participants also recognized the archeologist must relate to the rest of the world, but how are they really relating? If a sponsor has funded a project, he has the right to expect that the report for which he pays has more than a generally quite small proportion devoted to his planning needs. The means and the needs to preserve and protect sites are not side issues to science. They, in fact, are the issues! Archeologists will often fail in regard to cultural resource management (and to science) when they enter a contract with attitudes such as: How do I do the best archeology? How do I please my peers? How much research can I get out of this contract? How do I best tailor it to fit my desires? A contractor must enter into a contract with the attitude of how to do the best archeology possible which will result in the best management possible of the resource.

It is the author's opinion that the archeologist does not understand the legal requirements of cultural resource management. It is not unusual to find a project completed by a university for an agency or private firm 
involving site excavation on public lands without consideration of National Register significance of the site prior to excavation or destruction. Some appear unaware that the Bureau has the right and obligation (under $36 \mathrm{CFR} 800.4$ ) to review any and all work on publis: land for compliance. The universities have frequently failed to even notify the Bureau of their presence and activity upon the administrative lands of the Bureau. It remains that the universities still do not have a clear understanding of what cultural resource management consists of other than wanting it to be archeological research. Management is seldom addressed in more than vague terms. It is the author's opinion that the universities are producing archeologists trained to do archeological research and are not trained to do cultural resource management.

In addition to archeologists at the universities, it is becoming more common to have independent archeologists as consultants working on contracts. The general feeling among the archeologists at the universities seems to be that these independent archeologists are unqualified and should not be allowed to participate in oregon archeology. This is based upon the assumption that they do not have the necessary infrastructure for research (McGimsey and Davis 1977:54-58) and that they are perhaps professionally unqualified (King et al. 1977:189). Great care should be 
taken by the university personnel in this respect as they may be open to libel suit if they try to stop these persons from working or publicly question their qualifications.

If the Bureau were to limit contracting with universities only; which can not be done legally, it would severely limit the number of people available for contract work. This could lead to delays and backlogs. The only way in which the universities can prevent the independent contractor from operating is by providing better service and better reports at a competitive price.

\section{Public Relations}

While the archeological faculty members of State supported institutions are public servants, they have seldom dealt with the interests of the public. While there have been regular contacts and some cooperation between collectors and professional archeologists, little has been done for the general public. No general texts on Oregon archeology, except for Luther Cressman's Prehistory of the Far West, have been written and published. This is in direct contrast to the number of books by amateur archeologists and collectors. There are no good public museum displays in Oregon archeology. Little of the material of Oregon's prehistory is used in the schools. In general, the archeological community has a very bad public image in much of oregon. The professional is 
looked upon as a robber of what belongs to the public: They will take it away and put it in a drawer where nobody can see it, is one of the most repeated references to professional archeologists heard in the state.

The Oregon archeologists are well aware of this image and most would like to remedy the situation. The confines of time and money are given as the main reasons why they can not. There are some archeologists, however, that while they understand the problem, refuse to make contact with the public.

The public's views of the archeologists will reflect directly on the public support the Bureau's Districts can anticipate for their cultural resource management programs. In an area where the archeologist is disliked or distrusted, it will be hard to obtain site information from the local population or to get them to help preserve and protect the resource.

It is the author's opinion that the archeologists in Oregon (excepting a few) have failed in their duties to do archeological work on behalf of the public.

\section{Inventory and Material Storage Services}

The universities also provide the state and federal government with the curatorial needs of cultural resource management such as site inventories and the physical results of excavation work in the state. When a site has been excavated, the resultant artifacts, field notes, and 
reports are the remains of that site. These must be preserved for use in future research. The Museum of Anthropology (as recently reorganized) is the central repository for oregon; it also serves as a branch of the Smithsonian Institution, and thus as the official repository in the state for items removed from public lands. The Oregon archeological site files are also maintained there. This general inventory of sites and access to it has been a major concern and generated much conflict in Oregon. Some archeologists have maintained that only professional archeologists should have access to site records and then only if affiliated with a university. There has been much disagreement if consultant archeologists and federal archeologists should have access to these files. The State Historic Preservation office (See page 68.) does not have a complete duplicate copy of or access to these files.

With the reorganization of the Museum in 1978, federal agencies and others gained access to the files. The files themselves, however, need a great deal of work. A new system for storage, retrieval, and use of the files needs to be developed. The State Historic Preservation Office should have a complete list of all site reports and research reports on Oregon archeology. With potential funding problems, it might be necessary to remove the files from the Museum and make other arrangements. 
The other universities in Oregon also house extensive information about sites and reports to which the total archeological community does not have access. In some cases, it appears that these universities simply have not been asked for the data. This appears to be the result of territoriality as well as personal conflicts between the State's archeologists. It is clear that the oregon archeological community does not have a firm grasp on past work and data concerning oregon's prehistory or a system of central pooling of this data.

\section{HISTORIANS; ARCHITECTS, AND ANTHROPOLOGISTS}

These specialists have not been as actively in contact with the Bureau as have the archeologists. When they have, it has usually been in connection with one of the universities as a subcontractor or hired worker on a contract proposal.

It seems that the problems or needs of these specialists are not as critical or at least have not been openly addressed as have those of archeologists.

\section{NATIVE AMERICANS}

For the most part, the Bureau in Oregon has had little, if any, contact with Native Americans. Most of the project assessments completed to date have only vague notions of potential impacts to this group. The Bureau 
has been mainly concerned with the protection of Indian burial sites on public lands.

Generally, there has been no attempt to actively involve Native Americans in the Bureau's program of cultural resource management. The Native American organizations, on the other hand, have not actively questioned the Bureau upon its plans or goals. The situation is one of near total noncommunication.

\section{THE PUBLIC}

The public is one of the most important aspects of cultural resource management in oregon, yet the most maligned and neglected. Who or what is the public? Generally speaking, the public is all persons other than archeologists and others directly involved in cultural resource management. Most legislation dealing with cultural resources is passed by congress in the interest of this public. The premise of cultural resource management is to produce results for and in the interest of the public.

This public has a number of distinctly different aspects. There are two major divisions of the public which are readily apparent: those who are concerned with or interested in cultural resources and those who don't necessarily care about cultural resources. 
The Interested Public

The public has been called the single largest factor causing the destruction of cultural resource sites in North America. The literature refers to the destruction the public has caused and the inability of anyone to do anything about them (e.g. Stepherison 1968, Lee 1970, Davis 1971, Cole 1973, Grayson 1976).

It may be impossible in oregon or elsewhere to get an estimate of the total number of active collectors in the state. It would be reasonable to assume that anyone who finds an object of antiquity will probably remove it from where it was found, meaning that in reality, the entire population consists of potential collectors. There is, however, an active body of persons who specifically set out to find and collect cultural resources. In the Lakeview District, for instance, the author has made regular aircraft patrols during summer months. It has been estimated from these flights that on many weekends there are upwards of 200 collectors in the field in Lake County.

The collection of artifacts in oregon, especially eastern Oregon, has long been an accepted recreational activity. Often the entire family will be involved. The successful collector is often looked upon as a local authority on Indians and/or history of the region. Some have been collecting for many years. Earl Moore of. 
Central point, Oregon, recently published a book silent Arrows, which is a reminiscence of some 70 years of artifact collecting in oregon (1977). There have been others in oregon who have been as successful and have published (e.g. Seaman 1946, Woodward 1965, Howe 1968, Strong 1969). Their works have been met with acclaim from a grateful public interested in anything dealing with cultural resources.

The public's attraction to artifacts has made a successful business for Gene Favell of Klamath Falls, where the public pays for the privilege to view thousands of artifacts in his private museum.

It has been the author's experience over the last three years as a Bureau employee to make contact with more than a thousand artifact collectors either in the field or in informal situations. It would be reasonable to state that there is no typical collector. They range from the very young (four years old) to the very old (96 years old). They come from all walks of life, from medical doctor to the farmer. The collecting public has often included federal employees and law enforcement officers. Bureau employees working in the desert found it, in the past, a splendid opportunity to collect. The locations of Bureau projects were frequently archeological sites. Nearly all of the collectors which the author has spoken to reflect a genuine interest in the past. Many of these 
collectors are older, often retired. Trips are often made to favorite hunting grounds, especially on three day weekends.

It is also apparent that most collectors are aware that the collection of Indian artifacts is izregal. They are well aware that the archeologist feels they are causing destruction to a site, whether they agree with them or not. This conflicts with the views of many archeologists who feel that the public does not know their activities are illegal.

These collectors come from all over the nation and are not adverse to hardships and long travel. The author has met active collectors in eastern oregon who have come from as far away as New York to seek Indian relics. Most frequently, however, they are from within the western states. The Portland and Willamette Valley areas of Oregon hold a large number of Oregon's collectors.

Why do they collect? When asked this question (which the author has tried to ask each time a contact is made), a variety of answers are given. The most frequent answers are: To have a part of the past. Because the artifacts are beautiful works of art. The thrill of discovery. The pleasure of being outdoors. To save it from destruction. Because if I don't someone else will. Because I'm an archeologist and want to discover the past. Because my doctor told me to get out and walk around. 
The types of answers which are given are not that different from those which would be given by the professional archeologist. They reflect man's innate desire to know about the past. What is lacking in the active collectors is the discipline and training necessary to function within a realm of science rather than curio collection. This is not to say that some avocational persons have not made substantial contributions.

The collector also lacks the ethic that the past belongs to the public as a whole, rather than to him. They often fail to acknowledge the damage they may cause. Many seem to feel that artifacts are limitless in some areas,

with the oregon deserts' richness of archeological material, even a first time visitor can find a tangible piece of history and take home with it a portion of the natural atmosphere (Moore 1977:33).

It would be reasonable to estimate that several million arrowheads have been removed from Lake County alone. However, many collectors note that finds are not as abundant as they once were in Oregon. The apparent decline of surface finds plus public awareness have led to an increase in digging of sites. Some collectors reason they want to get it while they can. There is at times a profit motive for those who dig. It is reported that at least one Lake County resident earns his livelihood through the sale of artifacts. The outlet is reported to 
be in California. In Lake County and Harney County, the Chambers of Commerce publicly endorse the collection of artifacts.

It is the author's opinion that the Bureau has a major problem with the collector segment of the public. They cause a great deal of damage to the resource base, do not actively support the Bureau's cultural resource management program, and are distrustful of the university archeologists.

The Apathetic Public

The second major part of the public is the general public, those who do not particularly care or think about archeology or cultural resources. This is the apathetic public. While they are not the ones who are destroying the nation's cultural resources by collecting, they are allowing it to be done: The collector knows he can operate without fear of his neighbor's disapproval. While encouraging or approving of land disturbing development, the public may be unaware of the destruction of cultural resources caused by the projects. While the archeological community has done little in the past to inform and to educate this segment of the public regarding cultural resources, they are generally interested in them.

The appeal of cultural resources is not lost on the apathetic public. The popularity of archeology, history, fossils, etc., in the press, movies, and schools 
is apparent. The number of anthropology courses at universities far outnumber the number of anthropologists produced.

The major part of the apathetic public is not aware that they are being neglected by archeologists. If they are aware, it will likely be a negative feeling. The press which cultural resource management receives today is often pointing out how the taxpaying public is being taken by public archeologists.

\section{Developers}

Another segment of the public apart from the collector and the apathetic public is the developer. Legislation regarding cultural resources hàs placed restraints upon many construction projects. The developer is concerned that cultural resources will hold up or stop his development.

In terms of money, he may bitterly oppose the need for archeology (though many will fund archeology and gain good neighbor points). The developer may be confused as to what his needs are, how he can fulfill them, how much it should cost, why he should be concerned about cultural resources at ali after he worked for years doing nothing, what the public wants, the secrecy of archeologists, etc. (Neuschwander 1976).

He may also be totally confused or outraged when he can not find the needed personnel to do the job or 
contracts with a person who appeared to be qualified only to have another professional challenge that person's qualifications or the content of the report. There is also the added problem of archeologists giving private corporations clearances for their projects on federal lands without even contacting the agency.

What of the public's relationship to the cultural. resource professional? In 1960, Robert Ascher analyzed 10 years of Iife magazine articles dealing with archeologists to determine their public image. He determined that during those 10 years, the archeologist was portrayed as the seeker of the earliest, the biggest, and the most, rather than as a scientist (Ascher 1960). He points out that the public view of the archeologist was one of a technician. Archeology itself was depicted as chance discovery and adventure. He points out that A. V. Kidder in 1949 had identified archeologists as "the hairy-chinned and the hairy-chested" (Ascher 1960:402).

A perusal of the literature and other forms of mass communication of today would indicate that these types and more are still with us. How the archeologists or cultural resource specialists are perceived will in many ways affect their capability to function. Social-cultural relationships have been sorely neglected by the cultural resource profession. 
The Funky Image. This image can be equated to Kidder's hairy-chinned image. In this image the archeologist is viewed as an old, mustached or whiskered, bespectacled codger dressed in jungle fatigues and pith helmet. In his hand he holds a looking glass. He is usually found poking around abandoned temples, tombs, or museums. He is usually British. He is viewed more as an antiquarian, a seeker of objects for museums, than a scientist.' The funky type really does not enter the mainstream of life, but prefers to seek out the comforts of musty books, museums; and libraries. He lives in the past and gives little thought to today or the future. Quite often he seeks dinosaurs since archeologists are thought to be the ones interested in such creatures. The horror movie is often the home of the funky type, since his image is mostly the product of movies and television. In his poking around in search of a curse, he will usually be accompanied by his young beautiful daughter and his assistant, the young hairy chested type (Ascher 1960). While this image may seem a bit far fetched, it is very much with us. (Try counting beards at an association meeting some time.)

The Exotic Image. This image can be equated with Kidder's hairy chested image (Ascher 1960). Today, the image must be revised to include women as it is doubtful they would care to be the hairy chested type. This image 
again is the product of books, movies, and television. It is used whenever the unusual, the exotic, bizarre, or adventuresome is needed in the plot to make the male adventuresome or the female alluring. The nonconformist is also likely to be an archeologist.

Adventure calls from far off places. (What archeologist has not been asked if his goal is to someday work in Eygpt?) The popular press coverage of archeological work today is more often of the earliest, biggest, the most, the exotic, as it was in the years of Life reviewed by Ascher (1960).

The Ivory Tower Image. This image is the one most often held by the federal land use manager and the artifact collector. As compared to the others, it at least begins to approach the reality of the profession. The archeologist's world revolves around the university. He is a researcher and a teacher. He is quite outside the realm of reality. He produces reams of paper on how things should be done by the government and the artifact collecting public without ever leaving the university. He feels everyone should consider archeology the most important thing in the world. He feels he does his work for the university and his select group of peers and answers only to them (and really only to his peers), He views himself as working for the good of mankind but refuses to communicate with his fellow man. Only begrudgingly does he allow the 
public to view artifacts, after all, the sight will drive them wild and sites will be pillaged. He speaks a language only he understands. The products of his work are only available to the privileged few, published in obscure journals in unintelligible gibberish. His real function is to teach and reproduce himself. The public's view is that he is seeking to keep it all for himself. (He must have a collection of thousands of artifacts at home.) The land use manager feels he is being kept in the dark by this type and that the archeologist is feathering his bed with the profits of contracts. A former Lakeview District employee would have wagered that the management section of any cultural resource management report from any archeologist would state as its principal recommendation more work needs to be done.

The Lost Continent. Image. The last few years have seen a marked increase in the number of alternate explanations for man's rise to civilization throughout the world. The mass appeal of these explanations is apparent in the sale of books and depiction in movies and television. The threat of such theories to scientific understanding by the public has not been lost on the archeologist (Bumsted 1978). The attack of these theories by the profession merely causes them to be seen as the bad guys, the eggheads who can not see the obvious. Yet, they have not developed the capability of producing reports on scientific 
archeology for consumption in the public sphere. Is it so unreasonable for the public to listen to those who will bother to speak to them?

The fact that the public has been neglected by the profession is well documented in the literature (e.g. Stephenson 1968, Davis 1971, Dekin 1971, Ferguson 1972, McGimsey 1972, Wildesen and Witherspoon 1978) and need not be reviewed here. What is important is a look at why any of this matters. Why is involvement of the public really necessary? What can happen if they are not involved?

An experience in which the author was involved can serve as a prime example of what can happen not only with the involvement of the public, but also the lack of communication between archeologists and a federal agency.

The Bureau was involved with the Oregon State Highway Division in a project of widening and straightening a State highway. This project was strongly supported by the local community. The State Highway Division contracted with an archeologist to fulfill an archeological survey and obtain clearances for the project. The land in question is managed mostly by the Bureau, therefore, giving it jurisdiction over compliance with cultural resource stipulations. The first part of the project was accomplished with little trouble. Only a few minor sites were located and suitable mitigation was performed through excavation and site burial. It should be noted, however, 
that the contractor failed to make National Register evaluations prior to recommending excavation.

The second phase of the project developed problems. Numerous archeological sites were identified within the right-of-way. The archeologists working on the project did not regularly communicate with the Bureau as the project developed. No plans for mitigation or research designs were submitted to the Bureau. The archeologists apparently submitted a large budget for excavation to the State Highway Division. The State Highway Division decided to cancel the project supposedly due to archeology. The residents of the local community and many of the Highway Division personnel were extremely angered by loss of the improved highway. Letters were written by public officials condemning the archeologists for loss of the project. Newspaper articles in the local newspaper presented archeologists in a negative light. Significant research was not completed because of the cancellation.

What should have happened in this case? First, there should have been more communication. The archeologists should have kept the Bureau better informed on the project. Secondly, it appears to the author that the archeologists should have better informed the state Highway Division about the project. Communication with them by the author indicated that they knew next to nothing about the archeological work needed or its value. Thirdly, 
the archeologists should have personally informed the public about the project and the value of the resource.

Had these tasks been accomplished, it may have been possible to muster enough local support to have gotten the State Highway Division to continue the project. That way much needed research could have been accomplished and the public would have gotten their new highway. Even if this could not have been accomplished, more communication may have kept the archeology profession from becoming the fall guy.

\section{OTHER PARTIES OF IMPORTANCE}

There are a number of other parties who are of major importance to the Bureau and its cultural resource management program.

State Historic Preservation Office

The State Historic Preservation Office ( $\left.\mathrm{SH}_{-} \mathrm{O}\right)$ is one of the most important non-Bureau contacts in cultural resource management. This office was created through implementation of the National Historic Preservation Act of 1966. In order to qualify for federal preservation funds, the federal government required each state to create a state historic preservation office with a historian, an archeologist, and an architect on its staff.

The SHPO in Oregon is a part of the oregon state Department of Transportation, Parks and Recreation Branch, 
with its office located in the state capitol in Salem. The SHPO fulfills a number of vital functions in the management of Oregon's cultural resources.

The SHPO is responsible for the development and maintenance of a statewide inventory of cultural resource sites. This list of sites is to include historic, cultural, and prehistoric sites. Nominations of these sites to the National Register are prepared or processed by the SHPO. The statewide inventory is supposed to serve as the basis for development of a statewide preservation plan. The statewide plan and inventory to be developed by the SHPO could serve as the basis for development of a regional framework which has been proposed as necessary for the proper management of cultural resources (McGimsey and Davis 1977).

This does not mean that the SHPO will be in charge of inventory or management of sites on federal lands. The Bureau has specifically addressed this point (U.S. Department of the Interior, Bureau of Land Management 1978b). However, the federal government is required through the A-95 clearinghouse process (See page 17) to coordinate its plans with those of state and local government. In any case, the development of such a plan is in the interest of the Bureau.

The statewide inventory must be complete and available to those with a need to know. It will be one 
of the main sources of information determining if sites of importance exist in a project area. Care must be taken to insure that the state inventory is not misused. There have been instances of an agency asking for a records check, being told that no sites exist because no inventory has been done, and then having the agency state that the SHPO said that no National. Register quality sites are known to exist in the area of concern, but not state that no survey has been done.

The existing inventory in the sHPO is minimal. The historic file was updated by Stephen Beckham in 1976. While numerous sites were added, the sHPO warned "It should be remembered that the Inventory is not complete in this form. It will be revised and enlarged continually" (Department of Transportation, Parks and Recreation Branch, Oregon State Historic Preservation Office 1976:Letter of Transmittal). The listing of prehistoric sites as a part of the total inventory is lacking. The University of Oregon failed to date to provide the SHPO with a complete listing of sites. For those prehistoric site records

which the SHPO has, it is not unusual for the information to be sketchy and incomplete. The condition of some of these records is further complicated by their age. For instance, the first few sites in Lake county do not even have site reports, but are sites commonly known, such as Fort Rock Cave. Some of these sites may no longer exist 
because they were inventoried over 40 years ago.

The SHPO administers a grants-in-aid program providing federal matching funds for the acquisition or restoration of National Register properties.

The SHPo reviews major environmental statements and potential impacts of small projects to cultural resources through the A-95 clearinghouse process.

It is important that the views of the archeological profession be expressed to the SHPO. Specifically; this office is a political entity and it is essential that the profession participate and encourage state government to develop a viable program in cultural resource management. Presently, the SHPO is more oriented toward the preservation and protection of historic sites and structures than prehistoric sites.

While the Bureau is required under 36 CFR 800 to coordinate with the SHPO, the Bureau cannot direct the SHPO to do actual review work. For instance, if the Bureau requests an evaluation of the impact to a potential National Register site and the SHPO does not respond within the specified time, the Bureau can not require the SHPO to respond (36 CFR 800.5). What can and most likely will happen is that the Bureau will proceed with its review without comment from the SHPO.

The SHPO can serve as an independent source of support for the cultural resource specialist. 
United States Forest Service

The United States Forest Service, Department of Agriculture, could be considered a counterpart to the Bureau. While the Bureau deals principally in non-forested, grazing lands, the Forest Service deals principally with the forested areas of the state. Between the two agencies, they have administrative control over 50 per cent of the State's land area. Operational procedures, especially the planning process, of the two agencies are quite similar. Because both agencies control lands contiguous or in close proximity to each other, information sharing does occur between the two agencies. The possibility exists to reduce contract costs in many areas, such as survey work and overview reports, which overlap jurisdictional boundaries.

Heritage Conservation and Recreation Service

mraditionally, the responsibility for fedeial archeology work has been the National Park Service. In 1978, the archeological division of the National Park Service was subsumed under a new agency, the Heritage Conservation and Recreation Service (HCRS). The agency was combined from the Bureau of Outdoor Recreation, the Natural Landmarks Program, and the Office of Archeology and Historic Preservation of the National Park Service. HCRS has three programs: natural resources, cultural resources, and recreational resources. The 
agency's goals with respect to cultural resources are to be a focal point within the federal government for coordination of protection of the nation's cultural resources and to provide guidance and assistance to accomplish this task. With inclusion of the former office of Archeology and Historic Preservation, HCRS gained responsibility for administration of the National Register of Historic Places, the Historic Preservation Fund, the Historic Landmarks Program, the Historic Sites Survey, the Historic American Buildings Survey, the Historic American Engineering Record, as well as the duties of the Interagency Archeological Services and Technical Preservation Services.

HCRS will coordinate with state and local cultural resource management programs in the development of an inventory of the nation's cultural resources.

The agency will participate in a public education program regarding the use and value of cultural resources and to encourage public participation in planning.

HCRS will assume many of the problems of cultural resource management with the goals of producing solutions or at least standardization of methods and criteria. Specifically, it will address the National Register criteria, significance evaluation criteria, standards for identification of sites, documentation methods and preservation methods. The accomplishment of these tasks and others is vital. The problem lies in the potential for 
conflict between agencies, the resultant power struggle, and whether nonfederal personnel, as well as the general public, will be participants in program development. HCRS could wield tremendous power among other agencies and have considerable control over cultural resources. While a central authority may have benefits, it also has many pitfalls to avoid.

The reorganization may also create a new advisory council, the Council on Heritage Conservation. If created, its duties will be to advise the President on cultural resources, represent public interest in resolution of conflicts, review and comment on federal projects affecting cultural resources, issue advisory opinions and consult with federal agencies whose projects affect significant resources (U.S. Department of the Interior, Office of the Secretary 1978).

HCRS is less than one year old. Its formation and function may change with time as final guidelines have not been developed yet.' It should be noted, however, that technical reports and manuals are already coming from the HCRS offices (King 1978). Manuals of this type should be quite useful in the development of cultural resource management programs throughout the agencies, states, and private sector.

In any case, creation of HCRS is another major step on the part of the federal government to actively 
take a lead in cultural resource management.

Advisory Council on Historic Preservation

The Advisory Council on Historic Preservation was created as an independent part of the federal government by the National Historic Preservation Act of 1966.

The duties of the Council are to review and make comments upon the effects of federal undertakings and federally assisted or licensed undertakings upon sites listed on or eligible for the National Register of Historic Places. They also help coordinate programs, suggest changes needed in laws or regulations, initiate studies of preservation needs, and advise the. President and Congress on these needs (36 CFR 800). Additional duties include review of environmental statements for consideration of cultural resources, review governmental procedures for cultural resource preservation, comment on proposals to sell, destroy, or alter National Register quality sites, and assist in federal planning for cultural resources (36 CFR 800). 36 CFR 800 outlines the Council's responsibilities and procedures as mandated by NHPA, NEPA, and Executive order 11593.

These guidelines were recently revised and issued in January, 1979. The new guidelines substantially clarify the powers of the Council in matters of review of potential impacts to National Register sites and streamline procedures for completion of review. The guidelines also outline the duties of the state historic preservation 
offices and provide guidance for actions to be taken when previously unknown sites are discovered during construction.

Office of Personnel Management

An entity of federal government which is little thought about, but which is of major importance to the Bureau is the Office of Personnel Management (formerly the U.S. Civil Service Commission). It is through this Office that the Bureau will obtain their cultural resource management employees. The major problem of concern is that it is extremely difficult to hire someone on a fulltime, permanent basis, who is not approved by the office of Personnel Management. The system currently requires that when an agency has a position to fill, a roster of names of persons determined to be qualified to be archeologists is requested from the office of Personnel Management. (Currently, there is no job category for cultural resource specialist, which indicates a further need in the development of cultural resource management.) The agency usually must hire a person who is named on the roster.

How does one become a name on the roster? listing is dependent upon the wage grades for which a person desires employment. Archeologists in Oregon fall generally in the GS7 to GSI2 wage grades. GS7 grade and below are based upon a combination of a person's interests (indicating 
interest in the position of archeologist), final score on the Professional and Administrative Career Examination (PACE), and the person's educational training. For GS9 to GSI2 grades, the task is much simpler: completion of the required forms stating job interest and educational experience. If the person meets the requirements, he will be listed on the roster.

The problem with the above system is that the most qualified person may not get the job because he is not on a roster. There is also a potential legal problem if professional archeological organizations dispute qualifications designed by the office of Personnel Management for archeologist positions.

\section{Other Federal Agencies}

The Bureau in oregon may occasionally have dealings with the Army Corps of Engineers, Bureau of Reclamation, Soil Conservation Service, U.S. Fish and Wildlife Service, and the Bonneville Power Administration. Dealings will generally be in the form of services, joint projects, or information sharing. These agencies must adhere to the same legislation regarding cultural resources as the Bureau. Currently, most dealings are on an informal, personal basis. In the future, consideration must be given to formal plans for information storage, sharing of that information, and development of uniform management plans. 


\section{BUREAU OF LAND MANAGEMENT}

The Bureau is an agency within the United States Department of the Interior. The Interior Department is headed by the secretary of the Interior who is directly responsible to the President for the management of Interior Department lands. The position is a political office filled by appointment by the President. A number of undersecretary positions are directly under the secretary. Of importance to this thesis is the Office of Assistant Secretary of Land and Water Resources within which the Bureau is located. In 1946, the Grazing Service was combined with the General Land Office to form the Bureau of Land Management. The General Land office had been charged with the task of disposal of the public lands. Much of the land which remained in 1946 was arid, non-agricultural land in the eleven western states. This land remained public because nobody wanted it except for grazing privileges. The Grazing Service had been authorized under the Taylor Grazing Act of 1934 to regulate uncontrolled use of the public range and prevent further deterioration. There had been virtually no regulations up to 1934. The decision to manage these lands culminated in the creation of the Bureau of Land Management.

The Bureau is solely responsible for the management of what are known as national resource lands: 448 million acres (U.S. Department of the Interior, Bureau of Land 
Management 1976:1). These lands are located principally in Alaska, Washington, oregon, California, Idaho, Nevada, Utah, New Mexico, Arizona, Montana, Wyoming, and Colorado. These lands total nearly 60 per cent of all the nation's public lands. In addition, the Bureau manages mineral rights on 310 million acres where mineral rights were reserved by the federal government and administers minerals on acquired lands and the Outer Continental shelf. The Bureau is also responsible for survey of federal lands and maintenance of public land records.

In Oregon, the Bureau administers 15,724,455 acres of public lands. The breakdown of acres by county is shown in Table I. The Oregon State office of the Bureau also administers .3 million acres of Bureau land in the State of Washington.

Within these lands the Bureau manages or leases such resources as lands, minerals, timber, range, watershed, wildlife, and recreation. What is the potential for possible impact to cultural resources caused by these other resources in the state of oregon?

In Fiscal Year 1975, the Bureau projected 5,400,000 visitor days (a visitor day being one person on Bureau lands during any part of one day). Very little, if any, of this use was observed. This many visitors, without any form of supervision or direction, could potentially lead to extensive artifact collecting, especially in eastern 


\section{TABLE I}

LANDS UNDER THE EXCLUSIVE JURISDICTION OF THE BUREAU OF LAND MANAGEMENT

IN OREGON

As of September 30, 1978

County

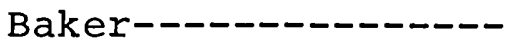

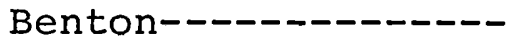

Clackamas-----------

Clatsop--0---0.--

Columbia----------

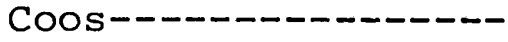

Crook-------------

Curry------

Deschutes----_-----

Douglas---_-_-_-_---

Gilliam-------------

Grant-------------

Harney------------

Hood River---.-----

Jackson---_-_-_-_-_--

Jefferson-----------

Josephine----------

Klamath-------------

Lake----------------



Lincoln-----------

Linn--------_--_----

Malheur----_-_-_-_--

Marion---_-_-_-_----

Morrow--------------

Multnomah-_-.--_-_--

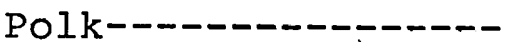

Sherman-------------

Tillamook-----------

Umatilla---_--_-_---

Union----_--_--_---

Wallowa---------

Wasco--_-_-_-_-_-

Washington--.------

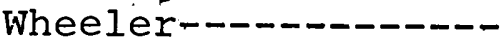

Yamhill-_...-.....

Total
Acres

369,942

57,390

62,906

43

11,085

166,647

511,341

67,510

518,534

653,509

23,717

170,950

$4,046,449$

180

430,910

26,063

311,483

288,549

$2,556,202$

290,052

23,941

88,198

$4,642,635$

20,934

35,886

5,880

40,996

43,403

48,559

8,857

6,250

20,690

35,731

12,335

87,200

39,498

$15,724,455$ 
Oregon.

The 2.2 million acres of Bureau forest in Oregon and Washington provided more than 1 billion board feet of timber in Fiscal year 1975. This amounted to: clearcutting of 16,812 acres and partial cutting on 42,742. Trees were to be replanted by hand on 30,415 acres. In the same year, 8,385 acres were precommercially thinned (cutting out smaller trees to add space and reduce competition for the larger trees) and brush which competes with commercial trees was removed on 12,050 acres. While the Bureau undertakes surveys to identify cultural resources, the groundcover of the western forest prevents surveyors from identifying sites until the areas have actually been logged or disturbed. The amount and types of disturbance which current and past logging practices have on sites is generally not known, yet on the western Bureau Districts, thousands of acres are logged, hundreds of miles of roads are constructed, herbicides sprayed, etc., every year. These activities have the potential to completely destroy cultural resources over many years' time.

In Fiscal Year 1978, the range program of the Bureau allowed livestock grazing on some 14,000,000 acres by over 290,000 cattle and 25,000 sheep by some 2,000 operators. The management of range for livestock use involves brush control, range land seedings, wells, reservoirs, spring developments, etc. In the Lakeview District, for 
instance, over 60 new reservoirs and waterholes were constructed in Fiscal Year 1978.

Perhaps of all the impacts which may occur on Bureau administered grazing lands, none is more threatening, yet less understood and mitigated, than livestock grazing. Livestock in Oregon is principally cattle with some horses and sheep. The effects of livestock grazing could be immediate and long-term, minor and major. The basic vegetation upon which the prehistoric peoples survived has been changed and altered. The reconstruction of an area's past lifeways can not be directly related to the present environment. This will cause numerous delays and costly problems in climatic reconstruction.

The environmental effects are felt to be significant to more than just the cultural resource manager.

Simply put, no other activity covers so much land area in this country as cows eating grass. Nor, with particular reference to the eleven western states where more land is grazed than in any other region, has any single activity or combination of activities contributed more toward altering the shape and texture of the land and the wildife that is dependent upon it (Fradkin 1979:94).

It is stated that 622 million acres or 83 per cent of the states of Washington, Oregon, California, Idaho, Nevada, Arizona, Utah, Montana, Wyoming, Colorado, and New Mexico have been or are being grazed. About half of these lands are said to be public (Fradkin 1979:94). In Oregon in 1978, there were 911,748 AUMs permitted (an AUM is an animal unit month; one cow for one month). 
What about other types of impacts by livestock grazing? Impacts can be broken into two groups: those caused by livestock and those created for livestock.

Besides changes in the vegetation, livestock can probably be credited with breakage and scattering of materials in a site, mixing of strata in wet sites such as springs, bogs, or whenever a site becomes wet, erosion caused by soil disturbances or lack of groundcover, compaction of soils and changes in the chemical composition of soils.

Impacts caused on behalf of livestock are numerous. Some of these are: reservoir construction, wells, pipelines, waterholes, spring developments, fences, vegetation chainings, plowing, range land drilling of grass, herbicide spraying, corrals, and powerlines. All of the above can or may impact cultural resources. Taken individually many of the above potential impacts may be quite minor, appear to have no effect, or one which can not be documented due. to lack of data. Taken as a whole, over a long period of time, however, the potential impacts may be substantial.

How can these potential impacts be handled in evaluation of projects in environmental assessment and National Register evaluation?

The more obvious impacts such as fence construction can be handled quickly and easily with solid basis 
for recommendations by the cultural resource specialist. Some of the others, however, are not so obvious and solid data upon which to base recommendations are not available. What is the impact of a cow walking upon a site for one month? How much disturbance is caused by the typical range land drill? What effect does removal of grass on a slope have on downhill movement of materials within a site? The potential impacts to cultural resources have not been quantified to date although some work has been done in assessing these types of impacts '(Roney 1979).

What are the potential livestock grazing impacts for the future? It is reported that the state of Nevada, Bureau has plowed or chained some 4 million acres of land (Fradkin 1979:102). Such practices will probably continue in the future.

In October of 1978, President Carter signed into law the Public Rangelands Improvement Act. This law provides $\$ 365$ million over a 20 year period to be used for on-theground range improvements such as those listed above.

Fire control programs in 1974 involved 342 fires on 42,296 acres. Various methods are used for controlling and extinguishing fires. These methods might consist of using hand tools to clear a fire line or using heavy equipment to clear the line. Fire retardant dropped by air is also frequently used. Besides the potential damage to cultural resource sites by fire fighting, there is further potential 
for disturbance by rehabilitation work.

Soil and water programs involve the mapping of soil series and protection of watershed. Protection of the watershed may include fencing to keep livestock out or seeding of grass to stop erosion.

Fish and wildlife programs mainly involve habitat management or improvement. This may involve fencing to keep out livestock or planting of various plant species.

The Bureau mineral program administers geothermal steam leases covering 195,000 acres and oil and gas leases covering 453,000 acres in Fiscal Year 1978. In addition, the mineral program administers the nation's mining entry claims and mineral uses such as gravel or rock quarries.

The road system which is maintained by the Bureau in Oregon and Washington exceeds 16,000 miles of road. Roads are built and maintained for access to timber sales, grazing and recreation areas, mining claims, and other management activities.

It should be clear by now that the activities of the Bureau and those allowed by the Bureau have a potential for a tremendous amount of land, i.e. site, disturbance ranging from individual fence post holes to the strip mining of several thousand acres.

Organization of the Bureau

The Bureau in oregon and Washington is divided into 
eleven District offices with their headquarters in Salem, Eugene, Roseburg, Coos Bay, Medford, Prineville, Baker, Lakeview, Burns, Vale, and Spokane. A State Office, which has responsibility for the eleven Districts, is located in Portland.

The organization of the Bureau is set up on the conventional line-staff and chain of command concepts. The Bureau has a system of line managers who are supported by an operational division of staff specialists. The line managers are the decision makers. Their staffs provide the expertise and recommendations upon which they make their decisions.

The Bureau has four basic organizational levels nationwide. These are the Washington office (WO), State Office (SO), District Office (DO), and the Resource Area (RA). Each of these offices has a line manager who has authority for that office and those below and responsibility to the office above.

The Washington Office is the national headquarters for the Bureau. The Director, who is appointed by the President and approved by Congress, is the chief executive of the Bureau. It is the Director's responsibility, to direct, coordinate, and control the activities of the Bureau. The Director's Office is ultimately responsible to the office of the Secretary of the Interior for the Bureau's operations. The Director's Office must see to it that the actions of the 
Bureau are in keeping with national interest and policy. It is the primary contact point for the Bureau with the Department of the Interior, with other branches of government, user groups, news media, etc., at the national level. The Director's Office is assisted in decision making by the Washington office staff. The assistant directors, divisions, and special offices provide support and expertise to develop policy, procedures, and regulations, and to review and regulate the field programs. Cultural resource expertise is one of many provided within the Bureau at this level.

The Director's Office is a critical political office within the federal structure in regard to cultural resources. The person appointed to the office will reflect the President's attitude toward cultural resources and programs will be designed to reflect that attitude. The appointment of an environmentalist to the position might serve cultural resources more than that of an economist. The tenor of the Director's office will be passed down the chain of command through the line managers. It will decide to some degree the emphasis which a program will receive within the Bureau and the way in which that program is handled.

The State offices are the next level of organization within the chain of command. They are an intermediate, administrative level. Whether a state has a state office 
is dependent upon the amount of public lands contained within the state's area. Most Bureau lands are located in the eleven western states and Alaska. Bureau lands in the east and the Outer Continental Shelf are administered by Regional Offices. This thesis is mainly concerned with the eleven western states, specifically Oregon. These Offices are named after the state (or in the east, the group of states) which they serve.

The State Director is responsible to the Director's Office for activities of the Districts within his state. The state Director is assisted in this task by associate directors and staff specialists. The State office provides technical advice, some technical experitse, and policy guidance to the District Offices.

Similar to the Director's office, the tenor which is set in the State Director's office will reflect upon the status of various programs such as cultural resource management.

The District Offices are the field offices of the Bureau organization. The Districts are where the actual policies of the Bureau are carried out. It is at this level that federal undertakings happen on-the-ground. Each District Office has a District Manager (DM) who is responsible to the State Director for Bureau programs carried out within a given geographic area. The DM, as with other line managers, relies upon his staff for expertise upon 
which to base decisions regarding management of the resources. Again, the tenor which the DM sets will reflect upon the effectiveness of a program such as cultural resources.

The Resource Area (RA) is the operational subdivisions of the Districts. The RA has an Area Manager (AM) who is responsible for carrying out Bureau policy and program services within a RA. The AM is assisted by his area staff.

Within the Bureau structure, there are two special support offices which have Bureauwide responsibility. They are the Denver Service Center (DSC) Iocated in Denver, Colorado and the Boise Interagency Fire Center located in Boise, Idaho. They are responsible for the development, improvement, and dissemination of technology needed for the various activities of the Bureau.

The Boise Interagency Fire Center, as the name implies, provides firefighting services for many agencies. The activities of the Center are important because of the potential impacts which fires and the control of fires might have on cultural resources.

DSC provides technical assistance and administrative services to the other offices. DSC provides the basic standards, technology, and guidance for cultural resource management through the Division of Resources.

DSC parallels HCRS in duties performed on behalf of cultural resources. This duplication of effort could lead 
to conflicts between the two agencies in the future.

Bureau line managers can not be expected to have the expertise to carry out all of the various programs of the Bureau. They, therefore, depend upon the assistance of staff personnel in making decisions.

The staff specialist is responsible to advise and assist the manager. The specialist provides the best information he can regarding the resource and interpretation of Bureau policy, applicable federal laws, and regulations: The staff person does not have the authority directly to make management decisions. The specialist may develop and recommend Bureau policy, programs, and plans, etc., but only at the direction or discretion of the line manager. Since the specialist has only advisory capabilities, his influence on a program is dependent upon three things: (1) The standing of his resource program within the Bureau. The specialist's professional ability. (3) The specialist's ability to persuade.

The cultural resource specialist's responsibility within the Bureau organization is frequently misunderstood by outside parties. It has been the author's experience that persons direct their needs regarding cultural resources to the specialist rather than the DM. Some have refused to accept items regarding cultural resources from the desk of the DM, apparently assuming the cultural resource specialist had not been involved. This attitude 
is erroneous since the specialist can not make management decisions. It is also insulting to the DM and neglects an opportunity to involve and enlighten the decision maker.

\section{Budgeting}

The Bureau's annual operations are dependent upon a budget approved by Congress as a part of the annual national budget.

Each year the Bureau develops an annual work plan (AWP) of tasks it proposes to accomplish which determines its funding needs. The AWP is based on the policy, goals, and directives received from the Washington and state offices.

The District prepares a preprogram budget which is submitted to the Washington office for review and analysis. After review by the washington office, preprogram budgets are presented to the Director for review. Through his review, the Director decides which programs will have priority and highest needs. Program package directives are prepared which contain objectives and fiscal constraints.

Final Bureau budget requests are submitted to the Office of Management and Budget by the Secretary of the Interior. Review by OMB leads to development of an overall program, issues, and budget. The OMB issues an allowance for the developing programs during an upcoming fiscal year. This is the Bureau's first cut budget (and it may be 
considerably less than what had been requested).

The Director's Office then prepares a revised budget program containing budget estimates, narrative justifications, and description of program accomplishments which is resubmitted to OMB. After final review by $O M B$, budgets are sent to the President for inclusion in the President's national budget presented to Congress. Congress reviews the budget and passes appropriations for funding. Congress may add monies to the budget if there is a specific need which can not be handled by the regular budget or is urgentIy needed due to constraints of time. A final budget is the result of a three year process. It is obvious why the needs of cultural resources must be identified as quickly as possible.

As with any program, funding is essential. The budgeting process provides the opportunity to seek increases in the cultural resource management program and when congressional "add-ons" can be approved for special requests.

Planning

The Federal Land Policy Management Act mandates the Bureau to use a systematic land use planning approach to the allocation of the nation's resources. The importance of the planning system for development of a budget for cultural resources can not be overlooked. First, regular programming of funds and increases of funds can only be submitted based upon an existing resource use plan. It is 
only through its planning that the Bureau can justify to the OMB, the President, and Congress, the funds which are requested. The need for increases or "add-ons" must be documented and justified through the planning system.

The purpose of planning is to "guide decisions for the range, timber and other resource management programs and to provide the proposed actions for related environmental impact statements" (U.S. Department of the Interior, Bureau of Land Management 1978e:58764).

The responsibility for planning follows the chain of command through the line managers as explained earlier.

A resource plan is generally based upon a political or management boundary of a geographic area. In Oregon, plans are based upon the existing system of Resource Areas within the Districts.

Resources of the national resource lands are segmented into operational divisions based upon specific resource activities. These activities include lands, minerals, forest products, range, watershed, wildlife, and recreation. Cultural resources are not recognized as a separate resource category and are located under recreation. Each of the resources has a specific set of goals which are to be accomplished in management of these resources.

The planning system which is in current use by the Bureau has four stages. These are the social economic pro- 
file (SEP), the Unit Resource Analysis (URA), the Planning Area Analysis (PAA), and the Management Framework Plan (MFP) (U.S. Department of the Interior, Bureau of Land Management 1975).

Social Economic Profile. SEP is an initial assessment of the total area of the District. It contains information on the socio-economic systems which are connected to uses of national resource lands in the District. It details the community infrastructure as related to public land uses. It presents the relationship of the Bureau to other agencies, special interest groups, and state and local government.

This document is designed to supply the nonphysical data for planning which is used to evaluate the significance of a resource value to the community.

In effect, SEP is an anthropological analysis of a region, although the Bureau has not specifically recognized it as such. Most SEPs are written from an economic perspective. The cultural resource specialist is not responsible for the preparation of the SEP, although it is feasible that he could. It is the author's opinion that this document would benefit from the input of an anthropologist during its preparation.

Unit Resource Analysis. The URA is designed to be an inventory process which identifies the current knowledge of the resources and their status. The URA should present 
everything the Bureau knows, or can learn from existing available sources, about the resource. A URA is prepared by the resource specialist for each resource.

There are four steps to the preparation of a URA: Step 1 is the preparation of a base map for display of resources, problems, proposals, etc. at latter stages. Step 2 is an identification, in narrative form, of the physical profile of the planning area. This includes climate, topography, geology, soils, vegetation, water resources, wildlife, fire, etc. Step 3 is an inventory of the resource, present use, present management practics, management problems, quality of the resource, etc. Step 4 is an identification of potential use and management of the resource. Step 4 is essentially the wish book of the specialist. It is a narrative development of all technologically feasible uses and management practices for the resource. It is developed without consideration of the effects of proposed actions on other resources. It is from these potential uses that actual management decisions will begin to be made and alternatives selected.

The URA for lands displays land ownership status, pending changes in land ownership status, lands to be retained in federal ownership, right-of-way grants, trespass cases, public service land grants, special land use permits, etc. Basicaily, it details the various existing uses on the public lands and the legal status of those lands. 
The URA for minerals displays the mineral potential of the District, the location of mining claims, mineral sources such as gravel pits, lands with geothermal, oil and gas, and coal leases, describes the geology of the District, and projects future uses.

The URA for timber displays the location of the forest areas, the type and amount of available timber, areas of past timber. harvests, areas which have been burned, areas which have been replanted, areas to be replanted, areas to be cut in the future, projected demands for timber, projected roads for timber harvests, indicates areas where brush control is needed, areas with erosion problems, and suitability of soils for growing trees.

The URA for range displays the various range pastures in the District, their condition, the type of vegetation, areas which have been planted to grass, areas proposed to be planted to grass, location of springs, creeks, waterholes, reservoirs, future potential water developments, location of fences, numbers of cattle, horses and sheep using the lands, areas cleared of brush, and areas to be cleared of brush (either mechanical or chemical). The URA for watershed details the soils of the District by Soil Conservation Service standards, details water location and sources, and identifies riparian areas, erosion areas, areas in need of protection or where erosion needs to be stopped. 
The URA for wildlife details the forms of wildlife in the District, where they are found (in what habitat), migration routes, nesting areas, winter ranges, summer ranges, and where habitat needs protection or improvement. The URA for recreation details the recreational uses of the District, fishing, camping, hiking, hanggliding, hunting, ORV, and bird watching. It details what people are doing, when, and where. In addition, the recreation section contains cultural resources, wilderness, and visual resources management.

The URA for cultural resources displays what areas have been inventoried and by what method, location of National Register sites or potential National Register sites, details the current status of knowledge of the resource; and identifies problems of management, research needs, protection or stabilization needs.

Management needs which have been documented and specifically addressed are harder to ignore than generalized, verbal recommendations.

The development of a URA according to a set plan will insure some continuity between Districts and states. Itwill also enable someone to know the status of the program within a District.

The general inventory data which the District's URA is based has great potential to serve archeology (York and Roney 1977:6). For each unit, as was pointed out, a base 
map was prepared. Maps generally cover an area of more than 2500 square miles, mapped at a scale of $\frac{1}{2}$ inch to the mile. The base map shows land status, general topography, and environmental data. Mylar overlays are prepared to display data which are coded to a narrative. These overlays show site locations, site types, excavations, types of surveys, areas of survey (whether negative or positive in locating sites), sites contained in published reports, National Register sites, reliability of an inventory, isolated artifact finds of special interest, site number, intensity of survey in an area.

A person will be able to determine the status of archeological research in an area after these overlays are prepared. It will be possible to formulate regional models, show where inventory work has been completed and where it is needed, indicate areas of site density, indicate land use patterns (York and Roney 1977:6).

In addition, the overlays and narratives which have been prepared for other resources can be used in conjunction with the cultural resource overlays. For instance, the wildlife inventory may indicate migration routes for deer or watering holes. Sites which appear to be hunting blinds might be known to exist on these routes lending support to the hypothesis that they are indeed hunting sites. If inventory has not been done in the areas of the migration routes, then they could be picked out as areas to be 
surveyed, especially if someone was researching aboriginal hunting practices. If you were interested in completing an inventory of sites at a specific water source such as small springs at 4500' elevation, the watershed overlay would identify your spring locations.

Large scale environmental reconstruction of past climates may also be possible using the Bureau's inventory data. The Bureau's Susanville District (California) has been working on a project of reconstructing pregrazing environments in the District using the available data on rainfall, soil types, and native vegetation (Corson 1977: 6-8). A hypothesis has been developed for the District's environment prior to white settlement with the resultant ability to compare located sites to the reconstructed environment, rather than the existing environment. This type of research appears extremely valuable for interpretation of land use patterns.

Planning Area Analysis. A PAA is prepared after the completion of the URA. While it is similar to a SEP, it is a more site specific document. The PAA is used to analyze social, economic, environmental, and institutional values within the area for which the plan is being developed. Its purpose is to identify potential conflicts between resource uses. The information will assist in conflict resolution in latter planning stages.

Management Framework Plan. The final stage in 
planning is the development of the MFP. The MFP is the planning stage when resource use decisions are made, based on the earlier steps in the planning process.

The MFP has three steps. Step 1 is formulation of recommendations by each resource specialist for the land use manager. Step 2 is an analysis of conflicts between resource uses and the development of alternatives. Step 3 is the making of a use decision by the land use manager.

The important aspects of the MFP process for cultural resources are steps 1 and 2. The decisions made in step 3 are dependent upon how well step 1 and 2 have been prepared or defended by the cultural resource specialist. The MFP is where resource use decisions are made: sites to be preserved, sites to be stabilized, sites to be excavated, sites to be nominated to the National Register. It is the specialist's opportunity to maximize his program. of course, cultural resources will be competing with the entire realm of resources, often for use of the same lands.

It should also be remembered that an MFP is a flexible document that can be changed as needs change. The current effort at writing MFPs for any District in Oregon is based upon limited and often antiquated data. As more data is gathered about the resource, MFPs should be revised to reflect this data. Currently important cultural resource sites may cease to be important in the future and new emphases developed. Ongoing inventory and research 
must be used to periodically update MFPs.

Resource Management Plan. Once the MFP is completed and an actual use decision is made for specific cultural resources or areas, a management plan will be prepared by the cultural resource specialist to carry out the management decision.

This plan is the Cultural Resource Management Plan (CRMP). The Bureau's goal to manage, protect, and designate appropriate use of cultural resources will be accomplished through this planning document (U.S. Department of the Interior, Bureau of Land Management 1978f).

CRMP's purpose is to provide all recorded cultural resources with an appropriate level of protection. The level of protection for the resource is dependent upon the inventory and evaluation process. If the resource is one site of a specific kind in a sample of 500 sites, it would tend to be very important and rate a high level of protection. If there are 497 other sites of this type in the sample, its appropriate level of protection would decrease. These levels of protection must be clearly identified and outlined through the various stages of planning. The design of a CRMP is dependent upon the status of the cultural resource inventory and development of a regional framework in which to analyze site needs.

Once a CRMP has been implemented, future funding needs of these cultural resources are to be drawn from the 
CRMP.

Public Participation in Planning. The public has a marked interest in the Bureau's planning process and a right to be involved. The Bureau is required to prepare a plan for public participation in its planning process.

While the Bureau is required to seek public involvement, resource users should make a commitment to become actively involved in the planning process. Sites of critical interest to researchers or preservationists can be considered only if these interests or concerns have been brought to the Bureau's attention. The chances for developing a strong cultural resource management plan will be increased substantially by voiced support from the public sector. Those persons interested in cultural resources must make some form of direct contact with the Bureau to make their views known.

The Bureau's current planning system will be revised in the future to meet the new mandates of the Federal Land Policy Management Act, the Federal Coal Leasing Act, and the Surface Mining Control and Reclamation Act. Revisions are also necessary to accomplish full and more expedient compliance with the National Environmental Policy Act and guidelines established by the Council on Environmental Quality (U.S. Department of the Interior, Bureau of Land Management 1978e:58764). The proposed rules have been published in the Federal Register of December 14, 1978. 
One of the important changes is a provision for a tiering of environmental assessment (U.S. Department of the Interior, Bureau of Land Management 1978e:58765). The necessary environmental evaluation for general potential impacts will be accomplished at the time of planning. Site specific plans and actions will require a more detailed impact assessment but will be aided by previous consideration made during earlier planning stages. Management decisions will thus be able to take environmental impacts into consideration better and at earlier planning stages.

Iike the present planning process, the proposed rules require public involvement and coordination with other agencies, state and local government, and Native Americans. The proposed rules refer to final plans as Resource Management Plans (RMPs) rather than MFPs. The goals of RMPs are to establish a means of coordinating multiple resource use, protection of areas of critical environmental concern (ACEC), and the allocation of resources much the same as the MFPs.

The required process for preparation of RMPs will be similar to the four preparation steps of MFPs. The process will include:

Identification of issues, concerns, and opportunities. Development of planning criteria.

Inventory data and information collection.

Analysis of the management situation.

Formulation of alternative plans.

Estimation of the effects of alternative plans.

Selection of preferred alternatives and filing the draft environmental impact statement. 
Selection of preferred resource management plan and filing of environmental impact statement.

Monitoring and evaluation of the plan. (U.S. Department of the Interior, Bureau of Land Management 1978e:58766).

It will be a number of years before all of the present MFPs are replaced by RMPs.

\section{Preparation of Environmental Statements}

The Bureau is required by the National Environmental Policy Act to prepare an environmental statement in order to analyze the potential impacts to the environment caused by a Bureau undertaking. Most of the projects developed through the Bureau planning process will require statements before they are implemented. The size of an undertaking will not be as important as its potential physical or social impact.

This would seem to insure that cultural resources would be considered fully. Whether or not this actually happens, or the degree to which it happens, depends upon the type of project, its magnitude, and the support which the project has from management.

Many of the projects which the Bureau undertakes are not analyzed through the preparation of an Environmental Impact Statement (EIS), but are analyzed in an Environmental Analysis Record (EAR). An EAR follows the basic format of an EIS, but in much less detail. The purpose of an EAR is to analyze the potential impacts, document the analysis process, and from the finding determine if the impacts are 
great enough that an EIS should be prepared. If the impacts are not great enough, the project will proceed based upon the conditions of mitigation identified in the EAR.

The EAR process reduces the time and cost involved in the completion of an environmental assessment. Frequently, a programmatic EAR will be prepared for many small, widespread actions of a similar type rather than a separate EAR for each individual action. If used properly, this procedure can adequately assess impacts. However, there is always the possibility that the EAR is written more as a justification for not writing an EIS than as an environmental assessment.

In the preparation of an EAR or EIS, the District must determine what potential impacts the undertaking will have on cultural resources. Alternatives must be developed which will lessen the impacts of the original proposal. Proposals for mitigation of impacts to cultural resources must be prepared. The environmental statement must be prepared prior to making a decision to proceed with the undertaking.

As in planning, public review and comment in the environmental analysis process is sought by the Bureau. It is important to cultural resources that interested parties make their views known to the Bureau during the analysis process. The cultural resource section of the environmental statements should be reviewed closely by 
archeologists, historians, and anthropologists. The A-95 clearinghouse process will provide an opportunity for the State Historic Preservation office to review statements. Comments which are received must be analyzed and answered by the Bureau prior to implementation of the undertaking;

The Bureau Cultural Resource Program

Within this framework of organization and land planning procedures is the Bureau's cultural resource management program. The program is outlined in the Bureau's Operational Manual: Section 8100, Cultural Resource Management and Sections 8110 and 8111, Cultural Resource Inventory and Evaluation.

These Manual sections contain what could be called the Bureau's cookbook of cultural resource management. The idea of a cookbook approach will appall and dismay many archeologists. There is a general feeling among archeologists that such an approach will stifle intellectual growth of the discipline, cause only basic, sterile work to be performed, and even worse, that they will not be allowed to perform any type of. work not outlined in such a cookbook.

A justified fear of many archaeologists is that those people charged with protecting cultural resources and those archaeologists doing contract arhaeology will work out a 'system', or a suite of methods, for fulfilling the letter of the various laws impringing on archaeology, and that they will allow no deviation from that course (Schiffer and Gumerman 1977: $x x$ ).

These are real and justifiable concerns. However, this 
approach is both necessary and quite beneficial to the field of cultural resources. The Bureau is a single (and staffwise quite small) part of a large bureaucratic organization. The sheer size of the organization demands the development of manual type planning. Such a manual sets out the basis for a cultural resource management program. It details its purpose, objectives, authorities, responsibilities to the land use manager.

The importance of a manual for cultural resource management is that it clearly directs the land use manager to consider them and integrate their protection and management with that of other resources. It becomes impossible to ignore them, which is what the Bureau has long been accused of doing. A manual is most important in Districts where a part or fulltime cultural resource specialist is not available or where staff is limited. It is also criticälly important to have a manual to support and protect the resource from the negative attitudes of some land use managers. It would be overly optimistic to expect all land use managers to be enlightened enough to share the archeologists', historians', or anthropologists' concepts of the importance of cultural resources. In reality, one will also find land use managers who oppose any consideration of cultural resources. When confronted by such a land use manager, the manual with its cookbook approach may be the only reason cultural resources are considered at all. 
Hopefully, the land use manager will use the manual as the basis for better and more refined resource protection and utilization.

Manual for Cultural Resource Management (8100). This manual provides the basic guidelines for the Bureau's cultural resource management program. The cultural resource management program "is designed to inventory, evaluate, plan and manage cultural resources on lands administered by the Bureau and in areas of Bureau responsibility" (U.S. Department of the Interior, Bureau of Land Management 1978b:Section 8100.01). Within this overall objective, more specific goals have been established for accomplishment of the program.

A. Protect and preserve representative samples of the full array of cultural resources for the benefit of scientific and socio-cultural use by present and future generations.

B. Ensure that cultural resources are given full consideration in all land use planning and management decisions.

C. Manage cultural resources so that scientific and socio-cultural values are not diminished, but rather maintained and enhanced.

D. Ensure that the Bureau's undertakings avoid inadvertent damage to cultural resources, both federal and non-federal (U.S. Department of the Interior, Bureau of Land Management 1978b:Section 8100.02).

These objectives form the backbone of the Bureau's cultural resource management program. They reflect national policy as mandated in the various laws. The present ideology of conservation archeology is present.

Objective A calls for preservation and protection of representative samples of the full array of cultural 
resources. Preservation of all remains of man's past activities on earth is simply impossible. The pressures for economic growth and the well being of the nation will demand and necessitate the final destruction of some sites. In the western coal states, such as Montana and Wyoming, entire regional areas may eventually be destroyed. The large expanse of the nation's public lands makes it virtually impossible to protect all sites from the ravages of collectors.

objective B clearly states that cultural resources will be included in the making of land use decisions. The obvious question which arises is how much weight will cultural resources be able to carry into such decision making processes? They may, in fact, be considered and then be destroyed because other resources carried more weight. As was discussed in the section on planning, it is in the area of planning that the work of the cultural resource specialist is critical. It will be his responsibility to speak for cultural resources in the planning process.

objective $\mathrm{C}$ is a reinforcement of objective $\mathrm{B}$. The Bureau has been given a clear responsibility to protect and preserve a large percentage of the nation's remaining cultural resources. The Bureau's task is to manage these resources in a wise and prudent fashion. If at all possible, the condition and chances for survival of cultural resources should be improved. 
Objective $D$ further strengthens the position of cultural resources. It reflects the tenor of Executive Order 11593 and the National Environmental Policy Act and clearly states that ignorance of cultural resources and destruction by benign neglect.will not be tolerated. This is critical in areas of high land disturbance where sites are widespread but not yet inventoried and evaluated (which is most of the Bureau's lands). Objective $D$ is designed to give all cultural resources the opportunity to be a part of the fult array which is to be preserved. The problem is how much consideration must or should be given to cultural resources prior to an undertaking to insure that inadvertent damage does not result. This is perhaps most critical in the forested Bureau lands where sites are often not apparent until they are exposed by logging operations. A preliminary search may not have exposed any sign of the cultural resources.

Manual for Cultural Resource Inventory and Evaluation $(8110$ and 8111$)$. The second aspect of the cultural resource management program is inventory and evaluation as outlined in Bureau Manual Sections 8110 and 8111, Cultural Resource Inventory and Evaluation. The express policy is

A. The Bureau undertakes and maintains inventories of cultural resources on lands under its jurisdictions and in areas its actions impact. Intensities of inventory are commensurate with management needs.

B. Cultural resources identified through the inventory process are evaluated to provide gui- 
dance for making management decisions regarding cultural resource use allocations (U.S. Department of the Interior, Bureau of Land Management 1978C: Section 8110.01).

The manuals detail the inventory and evaluation processes and uses of the inventory. An inventory is essential to the rest of the Bureau's cultural resource management program. The inventory is essential to the planning process because without a basic inventory, it would be impossible to assess the preservation and protection needs, the social importance, the significance and potential use of cultural resources, and funding needs. The basic inventory is required to meet the minimal standards for assessment of impacts to cultural resources during the preparation of environmental statements. The development of mitigation plans for specific projects depends upon completion of an inventory in the area of concern. Speculation will not meet the compliance requirements of the law. The inventory is essential in the development of CRMPs. To begin development of major programs for cultural resources prior to inventory would not accomplish the goals of the program.

The system of inventory which has been devised by the Bureau has three levels or classes of inventory: Class I, Class II, and Class III (U.S. Department of the Interior, Bureau of Land Management 1978d:Section 8111.1).

Class I Inventory is basically a review and compilation of the existing data available about the resource. 
These types of reports have become a standard of federal agencies and are generally referred to as a cultural resource overview or literature search. The report should contain information on the entire area of concern regardless of ownership. It must compile all known data on the area and provide a bibliography. The body of the review should include data on the environmental background, current and past research work, summary of collections, present research needs, and a description of the human use and occupation of the area, including prehistory, history, and contemporary cultures. It must also present management recommendations. The Class I Inventory is the document which will serve as the initial data base for URA and MFP preparation. Class II Inventory strategy is a field sampling or sample survey. The Bureau has prescribed a minimum 10 per cent sample level to provide representative samples (U.S. Department of the Interior, Bureau of Land Management 1978d: Section 8lll.130la). Methodologies for sampling of various size and type of areas are identical to those which have (or can be) developed for sampling of any area (Mueller 1975). The results of a class II Inventory should present a representation of past human use and occupation of the sample area, allow prediction of its cultural resource potential, identify areas of highest use, identify environmental variables/cultural variables that are important in human use, allow ability of density predictions and site 
types, and provide data for planning and site assessment. The Bureau will rely extensively upon class II Inventories to provide the necessary data for preparation of the cultural resource portions of environmental statements. The Class II Inventory will also contribute to solving inventory needs identified in the Class I overview.

The class III, Intensive Field, Inventory, is to record, from surface signs, all sites within a given area. The Class III survey will be required on any undertaking which will potentially impact sites or where 100 per cent of the sites in an area must be known.

Class III Inventories can be accomplished either by inhouse capability or through contract. Which method is - used will depend mostly upon the size and type of survey to be completed, funds available, and time available. In general, the larger, planned surveys will be done by contract, while smaller and emergency surveys will be done by the District.

To insure a complete inventory, it must also be the responsibility of the non-Bureau archeologists, historians, and anthropologists to report any and all sites of which they have knowledge to the proper District. Consideration for preservation and protection can only be accomplished for known sites.

An additional Bureau responsibility is for the storage and maintenance of site data, research results, and written 
reports which result from its cultural resource management program. Copies should be on file at the Museum of Anthropology and at the SHPO.

The Bureau has designed a site inventory system. Located sites are recorded on special Bureau cultural resource site report forms. These reports provide all the necessary information on location, site type, function, site affiliation, chronology, size, depth, environment, condition, past or present collection, excavation, research, maps, photos, etc., necessary for a complete description of a site. This data is organized for possible transfer to a computer storage system at some later date. Sites are then plotted on master unit maps to display, graphically, site type distribution and land use patterns. These maps can also be used to predict project impacts to sites. Written reports on inventory work are maintained at the State office and District office and distribution made of them as needed or requested.

All materials dealing with the exact locations of sites is considered to be working data and sensitive data, which must not be released to the general public. Details of location are generally not placed in public documents unless necessary. The District Manager is responsible for the safeguarding of site information from improper use and theft. This duty will usually be assigned to the cultural resource specialist. Site reports are kept under lock and 
key when not in actual use.

The amount of data which has become available for some Districts and the amount projected to be gathered by future inventories is becoming too large for ordinary storage systems. The rapid analysis and sorting of data is burdensome and time consuming. A more advanced type of inventory storage is needed which will allow better, faster, and more meaningful storage and use of the data.

\section{Relationship of the Cultural Resource Management}

Program to Other Bureau Programs. The overall management scheme of the Bureau dictates that cultural resource management will be integrated with other resource management whenever possible.

Much of the past integration has been in the form of support for other resource programs. All land disturbing or potentially land disturbing actions must be assessed for environmental impacts. Therefore, they all require a cultural resource evaluation. The completion of this evaluation by the cultural resource management program is support for other programs.

The cultural resource management program must also be integrated into the recreation management program. The basis for the existence of cultural resources is held partly to be in the socio-cultural recreational aspect of the resource. Therefore, it is essential that these two programs be fully integrated for best results for both. The 
recreational or humanistic aspects of cultural resources are not to be managed by the cultural resource management program.

Recreation use of cultural resource properties for public education/interpretation purposes is managed through the Bureau's recreation management program in coordination with the cultural resource program (U.S. Department of the Interior, Bureau of Land Management 1978b: Section 8100.08A2).

Such a division of responsibility could lead to conflicts. The recreation specialist may hope to maximize his program through development and utilization of cultural resources in recreation. The cultural resource specialist, on the other hand, may not wish to have sites excavated for interpretive purposes or have access to site areas improved for recreational sightseeing.

The Bureau addresses this potential conflict of interest

when cultural resources are used for recreation purposes, such recreational use must be managed to meet the cultural resource protection objective as stated in the approved MFP (U.S. Department of the Interior, Bureau of Land Management 1978b:Section $8100.08 \mathrm{~A} 16)$.

There is also the potential that a cultural resource specialist for personal reasons may encourage the development of a recreation management program which would lead to unwarranted excavation of sites on the basis of interpretive needs. This could be used as the justification for desired research by the cultural resource specialist. Inhouse research use of cultural resources is not the function of 
the Bureau's cultural resource management program. There is some concern that proper and needed research for better preservation and protection will be difficult, if not impossible, to do under the present manual because of its strict interpretation of research (Witherspoon 1978).

Cultural Resource Significance and Evaluation

The washington Office has prepared (July, 1978) a set of field guidelines for the evaluation of located cultural resource sites within a District (U.S. Department of the Interior, Bureau of Land Management 1979b). These guidelines are in draft form; but are operational. It is anticipated that only minor changes will be made before they are incorporated in Bureau manuals as a part of section 811l, Cultural Resource Inventory and Evaluation. These guidelines are somewhat analogous to a determination of significance, a matter which has generated a great deal of controversy in archeological literature (e.g. Scovill et al. 1972, Aikens 1976, Schiffer and Gumerman 1977, Schiffer and House 1977).

The basis for development of any form of significance criteria is twofold: (1) it is clearly mandated in the laws pertaining to cultural resource management, and (2) it is justification why a particular site should be preserved or funds expended on the site.

In developing a system for evaluation of cultural resource values, the Bureau has used the concept of 
multiple use.

Cultural resources are identified as a finite, nonrenewable resource of scientific and educational value. As a part of the Bureau's management plan, these resources must be inventoried, evaluated for potential use (significance), and an allocation made of that resource. The guidelines "have been developed for the analysis of scientific and socio-cultural values of cultural resources, and to provide a basis for land use allocation of cultural resources" (U.S. Department of the Interior, Bureau of Land Management 1979b). The guidelines enable the Bureau to consider cultural resource values in planning and environmental assessment and to comply with cultural resource laws. It also provides the Bureau with a consistent and uniform approach throughout the Bureau .

The evaluation guidelines have been designed into five use categories. Each individual site or group of sites is to be evaluated and placed into one of the use categories. The design of categories has been made to accomodate present actual use and potential future use. It should be noted that these uses address the scientific and educational use of the resource and not the potential for use as recreation in interpretive or visitor sites.

The five use categories are: socio-cultural use, current scientific use, management use, conservation for future use, and potential scientific use (U.S. Department 
of the Interior, Bureau of Land Management 1979b:Enclosure $1-2)$.

Socio-cultural use. This use category

refers to the use of an object (including flora and fauna), structure, or place, based on a social or cultural group's perception that the object, etc., has utility in maintaining the group's heritage or its existence" (U.S. Department of the Interior, Bureau of Land Management 1979b:Enclosure 1-2).

It deals with those cultural resources which are used by or perceived as important by extant ethnic groups. It is also the most nebulus and hard to evaluate of the use categories. Dealing with extant ethnic groups is not one of the more advanced or productive traits of a large part of the American archeological community. Historians, in general, are in a far better position to deal with such groups having dealt with ethnic groups as informants. The Bureau has not employed any anthropologists.

Let us briefly look at one socio-cultural site in Oregon which is located on Bureau-administered l.ands. There is an area of public land in eastern oregon which is annually used by a small group of Northern Paiute women for root and chokecherry gathering. Archeological evidence and ethno-historical data indicates that the gathering area has been used both historically and prehistorically, perhaps for several thousand years. The women who use the area do not depend upon their gathering for primary subsistence, nor do they obtain monetary gain from it. The women use the practice of gathering and processing traditional foods at a 
traditional root gathering camp as a means of keeping their heritage alive. It connects them with the past as the area is connected to the spirit of their people. The area of concern can be defined both in time and space. It contains cultural ties to an area of flora and campsite locations. Continued use is important in maintaining the group's heritage. The practices are being passed on to a few of the women's granddaughters.

This area will be evaluated as an area of sociocultural use and placed into that use category. However, the classification should not be made without careful consultation with the users of the area. Once classified for the land use, other conflicting resource uses which are identified or which arise, must be resolved through the planning process.

Perhaps one of the most common and most controversial of potential socio-cultural uses will be burials and cremation sites. While these sites are considered to be of scientific importance, they also have strong religious ties with extant Native American groups.

Current Scientific Use. Current scientific use is defined as

a study project in progress at the time of evaluation for which scientists or historians. are using a cultural resource as a source of information which will contribute to the understanding of human behavior (U.S. Department of the Interior, Bureau of Land Management 1979b: Enclosure 1-2). 
This category appears very clearcut in nature. Any resource which is known to be currently under study would fall in this category. However, it does not state whether a study has to physically touch the site or whether the person(s) doing the study must actually visit the site. In the author's opinion, any study, whether it physically touches the site or not, should be considered for placement in this use category. The resultant research may create new hypotheses which will lead to further study now or in the future which will physically touch the sites.

Management Use. The management use category is defined as

the use of a cultural resource by the Bureau, or other entities interested in the management of cultural resources, to obtain specific information (other than basic inventory data) needed for the reasonable allocation of cultural resources or for the development of effective preservation measures (U.S. Department of the Interior, Bureau of Land Management 1979b:Enclosure 1-2).

This use category has two distinct aspects: to obtain data to be used in making further evaluations, and (2) to obtain data to be used to preserve the sites after that evaluation takes place. An example might include the limited test excavation of a number of sites to determine the depth of these sites before allocation into one of the use categories. It may include the study of the effects of livestock grazing on a lithic scatter to determine the cumulative effect upon the site. Once the management use is completed, these sites would be reevaluated for allocation 
into another of the use categories.

Conservation For Future Use. Conservation for future

use is defined as

the management of cultural resources by segregating them from other forms of appropriation until specific conditions are met in the future. Such conditions may include, but are not limited to, development of research techniques which are presently not available, or the exhaustion of all other resources similar to those represented in the protected sample. The category is intended to provide longterm, in-site preservation and protection of select cultural resources (U.S. Department of the Interior, Bureau of Iand Management 1979b:Enclosure 1-2).

This use category is perhaps the most controversial and at the same time the most important of the categories. The conservation and preservation of American antiquities has been a goal frequently discussed by American archeologists and other preservationists. It is doubtful that archeologists would argue with the long-term conservation of sites. It is apparent from its inclusion that the Bureau is committed to the basic concept of conservation. However, archeologists and land use managers will potentially challenge this use category. Archeologists by their very nature consume the resource. There is no general agreement, nor often even discussion, on when a site should or should not be excavated in Oregon. The oregon archeological community may not be agreeable to the concept of a Bureau District cultural resource specialist locking up a body of sites and allowing no access to these sites unless certain conditions are met: In addition, there will also be 
disagreement on what sites should be placed into this category, how many, and for how long. When is there a representative sample of a site population? What is representative? How long will the site be kept? Will the forces of natural deterioxation be considered? What will be the fate of sites not included? Are these no longer worthy of protection?

The land use manager will also have to deal with the effects of this use category. The basic premise of the category is that a body of sites which appear to be a representative sample of the population will be preserved and protected for future use. Uses which conflict with this goal or which will culminate in destruction of the resource must be prohibited.

The long-term effect of this category may be a bright spot in archeology. If implemented properly, the Bureau may be able to insure the long continuation of archeological research in the western states.

Potential Scientific Use. Potential scientific use is defined as

the potential use of a cultural resource as a source of information which will contribute to the understanding of human behavior, utilizing research techniques currently available (U.S. Department of the Interior, Bureau of Land Management 1979b: Enclosure 1-2).

This use category is the immediate use category. These are the sites upon which current research needs will be performed. These are the sites which will be sacrificed 
today rather than preserved for the future. The category theoretically pertains to all sites known within an area. The basis for designation will be the research needs or objectives which are identified in the class I overview or which have been brought to light during the planning process. This category will also be used to fulfill the research needs of the universities' archeologists.

If there is insufficient data available to evaluate a site, the site is set aside until such time as the needed data becomes available for evaluation. Data needs is basically a sixth category, a holding category.

The holding category is important, for the Bureau's present use of the evaluation system. The system is designed for use in areas where a class II or Class III inventory has been completed. The guidelines state "the evaluation of cultural resources must be completed after the inventory"(U.S. Department of the Interior, Bureau of Land Management 1979b:Enclosure 1-1). In Oregon, none of the Districts currently have completed either Class II or Class III inventory on a large enough area to apply this evaluation system.

Once an inventory has been completed, the system can be applied. It will no longer be acceptable to state simply that all sites are significant and should be preserved. A detailed analysis of why a site has significance for one of the use categories will be necessary. 
The evaluation system has several functions: The system will be used to identify opportunities for future management in the URA. It will identify socio-cultural values for analysis in the PAA. It will provide regional data for use in writing environmental statements. Finally, it will help insure compliance with the cultural resource legislation.

The Cultural Resource Specialist

Within this framework of legislation, regulations, Bureau policy, Bureau organization, and outside contacts, the cultural resource specialist must operate on a daily basis.

All of the cultural resource specialists presently employed by the Bureau in Oregon have been hired as archeologists. It has been noted earlier in the thesis that archeology does not encompass the full scope of cultural resource management. Thus, the use of rultural resource specialist more appropriately describes the work to be accomplished by the individual rather than archeologist.

The Oregon Districts of the Bureau have had full or temporary cultural resource specialists since 1975. For most of the three years prior to this thesis, the cultural resource specialist has operated with interim management policies and a vague notion of what the program should be. 
These three years has included completion of the backlog of cultural resource clearances for projects which had been designed and planned before the cultural resource specialist was hired, clearances for emergency situations, and, finally, the beginning of clearances for future proposed projects. These clearances have involved projects ranging in scope from the placement of a fence to survey of several thousand acres of timberland scheduled for clearcutting. These surveys have all been Class III inventories. Besides the completion of project clearances, the cultural resource specialist has assisted in the preparation of numerous environmental statements on timber production, oil and gas leasing, geothermal leasing, and other undertakings which require environmental assessment.

Initially, each District cultural resource specialist had to prepare a plan for site protection from artifact collectors, tell waiting land use managers what actions would be required to be in compliance with cultural resource laws, deal with a sometimes hostile Bureau work force, and a more than sometimes hostile public. Specialists also had to develop an existing inventory of sites, reports, and collections pertaining to the District.

Since this initial catchup and development phase and with the subsequent formalization of the Bureau's cultural resource management policies, a fairly stable and routine program has developed for the Districts. There will, of 
course, continue to be emergency problems, changes in emphasis, development of new techniques, etc., to meet the changing needs of the program. Without such changes, the program would quickly become outmoded and unable to complete the necessary tasks.

Because of the differences in geographic location, land ownership patterns, environmental settings, culture areas, etc., there are differences between the Districts. This will have an effect mainly on survey methods used in the forested western Districts and the range land eastern Districts.

Project Clearances. Providing cultural resource clearances for projects remains the single most important task of the cultural resource specialist. This requires an assessment of the area and any literature pertaining to it, development of survey needs, survey methods, and research objectives, completion of the actual survey, assessment of findings, preparation of a report, development of management recommendations, transmittal of inventory data to the necessary parties, and storage of the data in the District's inventory.

In addition, the cultural resource specialist must insure (with the District Manager's approval) that all the necessary compliance checks for the completed work and recommendations are made.

Inventory Records. The District cultural resource 
specialist is responsible for the updating, storage, and protection of the District's inventory data.

Contracting. The District cultural resource specialist must take a lead role in the preparation of contract proposals for work in the District to insure that contracts address the needs of management, meet current research proposal standards, and are realistic. The cultural resource specialist will generally take part in the selection process of a contractor. He may also be designated as the Contracting Officer's Authorized Representative (COAR). The COAR is responsible for insuring that contract stipulations are carried out, deadlines are met, evaluate the resultant work for contract fulfillment, and act as a liaison between the Bureau's contracting department and the contractor if problems should arise. The COAR will also approve the final project work and authorize payment of the contract. The cultural resource specialist, as COAR, must insure that the contract work meets all legal compliance needs.

Survey work by Others. The District is responsible under $36 \mathrm{CFR} 800$ to make sure that any clearance work for non-Bureau projects on Bureau lands meets legal compliance for cultural resource legislation. While others are responsible for cost and work completion on non-Bureau projects, the Bureau can not delegate its responsibility for final clearance. It is possible that a District cultural 
resource specialist may reject another party's clearance report and refuse to issue Bureau clearance for a proposed project on Bureau lands.

Planning. The District cultural resource specialist is responsible for completion of the necessary planning documents and insures that full and proper consideration is given the resource. This involves preparation of the cultural resource sections of the SEP, the URA, the PAA, and the MFP, and, finally, preparation of CRMPs for the District.

The cultural resource specialist must prepare or assist in the cultural resource program funding requests and development of the subsequent annual work plans.

Environmental statements. The cultural resource specialist must provide the necessary expertise for preparation of environmental statements. This includes a description of the existing situation and analysis of impacts. The existing situation describes what cultural resources are present within the area of the proposed undertaking for which the statement is being prepared. Analysis of impacts includes the primary disturbances to the resource, the secondary impacts, such as erosion because of removal of ground cover, and analysis of what the long-term effects of the project will be upon the resource.

The cultural resource specialist must develop the necessary recommendations for mitigating the impacts.

Mitigation is a term which has been developed out 
of recent environmental legislation, specifically the National Environmental Policy Act. The federal agency must identify, analyze, and attempt to mitigate its impacts upon various resources. Impacts can take two forms: direct and indirect. Direct impacts are just that - direct. They are immediate in nature and can be easily identified. Indirect impacts are harder to identify. They result, however, from the project. Indirect impacts include access which causes artifact collecting, erosion caused by change in vegetation, or urban development brought about by the project. These type of impacts are long-term and some may take years to develop.

How then can mitigation of impacts be accomplished in regard to cultural resources? Mitigation for a project can take three basic forms: avoidance, preservation and protection, and data recovery or salvage.

Because the Bureau's program emphasizes conservation, avoidance will always be the preferable form of mitigation. Avoidance may be accomplished by modification of the project, movement of project location, or cancellation of the project. This form of mitigation has frequently been used by the Bureau in Oregon. It is usually the most expedient and least costly method of short-term mitigation. Secondly, the nature of many of the Bureau's undertakings is such that they can easily be moved, modified, or cancelled. 
Mitigation through preservation and protection is more difficult to define. Preservation or protection might involve fencing, burial, isolation, hiding, covering with grass, etc. It also carries an implication that the Bureau must protect a site which has become public knowledge through the environmental analysis process. Constant patrol may be necessary.

Salvage is perhaps the least desirable method of mitigation. The term salvage rather than research or conservation is used because that is exactly what is involved. The Bureau has commited a portion of the resource to destruction with use of this form of mitigation. Salvage recovers site data under existing standards. Antiquities Permits. The cultural resource specialist will act as the District's contact or representative in matters regarding the approval and compliance checks of antiquities permits on District lands. The cultural resource specialist must evaluate the needs of the applicant and make recommendations to the District Manager on permit approval or denial. The cultural resource specialist should incorporate other District staff concerns by placing special stipulations in the permit. An example of a recommendation from the wildlife specialist might be avoiding a falcon nest area during certain times of the year. The cultural resource specialist is responsible for compliance review of conditions and stipulations of the 
permit.

Communication. It is vital to a good cultural resource management program that strong lines of communication exist between the District and the state office specialist, other agencies and their cultural resource specialists, nonfederal archeologists, historians and anthropologists, historical societies, professional organizations, and the general public. The way in which these contacts are maintained will vary from District to District depending mostly upon distances and population.

Contacts with the Oregon State office can be both formal and informal. The necessary communication can be done in person if the Districts are located close to Portland. More often, the telephone or letter will serve as the main form of communication.

It is often worthwhile to contact the state office on an informal basis initially to discuss a major problem following with a formal request for advice, a decision, or assistance to the State Director's office. The state specialist will already be aware of the situation prior to being asked for advice from the Director's office on the matter.

It is also important for contiguous Bureau Districts to maintain good lines of communication. Districts can often share data, undertake joint projects, and provide assistance in the field when necessary. It is generally 
difficult to maintain communication across state lines. If at all possible, in the development of cultural resource management plans, political boundaries should be overlooked. The best means of communication between Districts is by telephone or personal contact.

It is important that the Districts maintain lines of communication with other agencies whose lands border the Districts. The cultural resource management programs, in fact, may be strengthened between two agencies due to location of cultural resource specialists in the same locale or sharing of the same cultural/physiographic region. There has, however, been a marked lack of formal program sharing between agencies and some duplication of work, such as Class I survey. The compilation of data on a region by agencies as a joint project would improve the regional cultural resource knowledge, assist in the development of a regional framework, and reduce costs.

Communication with archeologists, historians, and athropologists is important for transmittal of inventory and research data, land use planning, understanding of special needs and problems, contracting, training, and other purposes. It is also one of the most neglected areas of the Bureau's program.

Contact with nonfederal professionals is usually limited to times when these persons are doing field work in the Districts, contract negotiations, or at professional 
society meetings. In some cases the location of District Offices and universities will improve contact. The Eugene District, for instance; should have good contact with the University of Oregon, while the Vale District more likely would be in contact with Boise State University.

Contacts with societies, museums, schools, etc., will vary from area to area. These contacts are vital for planning, inventory and data sharing, and public education and awareness of the Bureau's program. Many of these informal contacts are made on the cultural resource specialist's own time. Contacts might include volunteer assistance in data collection, museum curation, artifact analysis. The goodwill and resource data which can be gained through such actions should not be overlooked. There has not been enough time devoted to such work. Oral history, for instance, has been particularly overlooked by agency programs, as has contact with Native American groups.

The District cultural resource specialist must also be the focal point of contact between the Bureau and the general public.. This contact may be the first positive contact that some of the public has had with archeology. The District cultural resource specialists are visible members of the community (especially in eastern oregon). They reside fulltime in the area and their actions can directly affect the land users, such as ranchers, tourists, and loggers. It is important to build a system of communi- 
cation with the general public to gain support, change attitudes, prevent rumors, and in general provide for public awareness of the cultural resource management program. Public education and awareness might include preparation of or interview for newspaper or magazine articles, preparation or assistance in preparation of books on the region, preparation of radio and/or television spots, public lectures in schools and to civic clubs, teaching night school, assisting historical societies, answering inquiries about archeological, historical, and anthropological remains on public lands, and creation of displays or pamphlets.

Significance Evaluation and Legal Compliance. Determining site significance in respect to legal requirements for a site potentially impacted by an undertaking of the Bureau is one of the most important and controversial duties performed by the District cultural resource specialist. It would be appropriate to state that an evaluation can not fully be made until a total inventory of an area, regional framework design, and contacts with all interested parties, are available. Reality demands that the evaluation of sites potentially to be impacted must be made now. It may never be possible for cultural resources to reach a point where all possible factors can be appraised prior to making a decision. Therefore, when a site is threatened, the District cultural resource specialist will 
make an on-the-ground assessment and an evaluation of the site's significance. This evaluation must be as clear and competent as any that would be required of a contractor: It must meet all the legal requirements, survive peer review, sHPO review, and potentially ACHP review. It may well have to stand court tests. It is, therefore, imperative that the cultural resource specialist take full account of the current legal, moral, and scientific methods for determining site significance. Whatever course of action is taken, the assessment must be fully described and documented for the record.

Once a determination of significance has been made, the cultural resource specialist must oversee mitigation and all further compliance review checks. This will usually require preparation of a 106 statement on potential National Register sites for the Advisory Council on Historic Preservation as required by the National Historic Preservation Act.

Law Enforcement. The District cultural resource specialist will be the coordinator of the District's cultural resource protection program and will probably take an active part in field patrol work. While the Bureau employee is required to be alert for any violations, only those specifically assigned to partol work and the cultural resource specialist are likely to report violations. Because of the lack of fulltime District law enforcement 
personnel and lack of adequate arrangements with local law enforcement authorities to date, the bulk of site protection will be done by the cultural resource specialist.

Field contacts with collectors are likely to occur on a regular basis in most Districts. The cultural resource specialist, in the state of Oregon, can not arrest violators (without threat of suit) because he has no authority beyond that of any other citizen. He can only gather information regarding a potential antiquities violation and turn this over to the proper law enforcement authorities for investigation.

Paleontological Programs. In most Districts, the cultural resource specialist will also be responsible for coordination and development of a paleontological resource: program. Because of the overlap of fossil fauna with paleo-Indian studies and protection of fossils under the 1906 Antiquities Act, it is logical to give this program responsibility to the cultural resource specialist. The formal Bureau responsibility has been placed under the Division of Watershed. Therefore, the cultural resource specialist must cooperate with the watershed program for the development of a paleontological program through the planning process.

Training. The District cultural resource specialist may be responsible for the training of assistants and for general awareness programs for the staff. With the limited 
manpower and funds available to the cultural resource management program, assistants may be necessary to help complete some inventories. These assistants are only trained in the recognition and recording of cultural resources. They do not have the authority to analyze, collect, or provide any type of project clearance for cultural resources. Besides survey assistance, it is beneficial to have other employees in the field who are capable of site identification and site inventory. The more Bureau employees are aware and know about cultural resources, the more likely they are to assist and favor such programs. They can also provide information and understanding through further contacts with friends and relatives.

Research. The District cultural resource specialist will generally be expected to do only limited research. The objective of the cultural resource management program is preservation and protection for eventual use, not the actual use itself. However, any type of inventory or evaluation necessary to make proper management decisions must be based on a certain amount of research.

While it may be difficult to justify research as an end in itself, the Oregon District cultural resource specialists are in a unique position for potential research. Because of the amount of time which is spent in an area, the specialists become familiar with it both culturally and environmentally. They should develop a working knowledge 
of the available data on the District. Personal interests in research may develop regarding a specific aspect of a specialists' District. It is probable that research may be undertaken independently of the Bureau's program on the specialists' own time.

National Register Nominations. The District is required by the National Historic Preservation Act and Executive order 11593 to nominate those sites which have been determined to be of National Register quality to the National Register of Historic Places. The cultural resource specialist is responsible for the preparation of the nomination on behalf of the District.

Defense of Cultural Resource Management. It appears that District land use managers do not take the recommendations of the cultural resource specialist or contractor at face value. In one instance, an archeologist evaluated a particular site as being eligible for the National Register. When an area manager, who wanted to propose a project within the area of the site, was told that such a site existed and that the project could not go forward without completion of the legal compliance process, he immediately questioned the archeologist's evaluation. He desired to know how one went about checking the competency of the archeologist's evaluation, what review could be made of the evaluation. He refused to accept the evaluation of a trained specialist and sought means to challenge it. No 
doubt, in other cases, land use managers have challenged other specialists in the same fashion. The outcome of the matter was a three day discussion between the author, the area manager, and the District Manager on the significance of the site. This occurrence is not unique to the Bureat. Conversations with other cultural resource specialists reveal similar challenges. The problem is two sided. On the one hand, there is the land use manager who must make resource allocations of frequently conflicting resources. The land use manager will probably have little or no training in cultural resources and often may be unsympathetic to the cause of cultural resources. If unsympathetic, the land use manager will question the need and degree of cultural resource mitigation. In contrast, the archeologist or historian working under contract is highly supportive of the resource with which he works. The contractor may know little about the proposed project which created the need for his work. The contractor may consider the project only as a threat to the resource. The report which the contractor prepares may be written in technical language. The needs of the land use manager may not be understood and properly dealt with in the report. The contractor expects that statements of value, i.e. site significance, to be taken at face value by the land use manager.

In addition to the above basic differences, it 
has been noted by many land use managers that the recommendations of archeologists and historians in past contract reports have varied greatly with respect to significance. One person's important flake scatter is another person's non-site. While the professional cultural resource person can understand such differences, the noncultural resource person sees it only as a sign of archeology not really being a science.

Thus, it is the responsibility of the cultural resource specialist to provide an interpretation of recommendations to the land use manager. 
CONCLUSIONS AND RECOMMENDATIONS

The Bureau has developed a systematic approach to the management of cultural resources. The program is relatively new and has some general problems. It has been noted also that there are problems with other parties, including the non-federal archeologist and the public, in dealing with cultural resources in general and the Bureau's cultural resource management program specifically. The remainder of this thesis will present some recommendations that address potential solutions for these problems.

\section{PUBLIC INVOLVEMENT}

It has been noted that the public is one of the biggest threats to cultural resources, has been neglected by both archeologists and the Bureau, and is an untapped body of potential supporters of a cultural resource management program. There are three needs which must be addressed in regard to the public. (1) The Bureau must actively seek public support and provide goods and services to them. (2) The archeologist must begin to relate to the public and provide goods and services to them. (3) The public must become more aware of the destruction caused to the 
resource through their actions and begin to regulate themselves.

\section{Warden System}

One method to involve the interested and avocational public in cultural resource management and help prevent destruction of the resources is creation of a warden system.

The provincial government of British Columbia has supported a system of wardens since about 1976. The warden system was organized by the Office of Provincial Archeologist after receiving recommendations from a Committee of the Archeological Sites Advisory Board of British Columbia.

The purpose of the system is the protection of archeological sites. The wardens act as liaisons with the land managing agencies. The duties of a warden include:

enforcement of the archaeological aspects of the Archaeological and Historic Sites Protection Act, including reporting violations of the Act and reporting on site locations; and

Education of the public regarding the Act'; provisions and the philosophy of site protection (Sneed 1976:3).

Wardens are selected by background and geographic location. Each warden is assigned to a specific area. The wardens are then given brief training in archeology, functions of the Provincial Archeologist's office, antiquities acts, responsibility of wardens, and techniques of inventory. Wardens are not simply to report on violations by collectors to the Provincial Archeologist's Office. They also can report the actions of governmental agencies 
and private enterprise when those actions may (or do) impact cultural resources.

The goals of such a program are simple: it provides a means for public participation, provides a means to patrol collectors, agencies, and anyone else who may impact sites, and provides an invaluable public awareness program of cultural resource values.

It is suggested that such a system could provide a means to involve oregon's public and to help stop site destruction by collectors. Stop oregon Litter and Vandalism (SOLV) is based on the same public involvement concepts. Such a system could be organized by either the Association of Oregon Archeologists (AOA) or the State Historic Preservation Office. The State Historic Preservation Office and/or Bureau District archeologists could serve as contact points for wardens. Training and guidance of wardens could be provided by the archeological community on a volunteer basis. Funds would probably be limited or nonexistent for such a system.

Such a system would provide a number of benefits. (1) Public education and awareness through the wardens of persons in their communities who might not listen to a professional. (2) Better protection of the resource by patrolling collectors. (Peer pressure can increase compliance with cultural resource laws.)

(3) Patrol federal and state agencies to help insure adequate measures to 
preserve and protect the resource are taken. (4) An increase in inventory records. (5) A means of gaining public input for planning and lines of general communication between professionals and amateurs.

Persons involved in such a system should know that they have no legal authority for arrest except that of the citizen (unless they happen to be a law enforcement officer), that they would not have general access to state, federal, or university site files, and that collection or excavation except as supervised by professionals would not be tolerated.

\section{Bureau Contributions}

The Bureau should begin to provide some of the benefits of its cultural resource management programs to the public. This can be accomplished in a number of ways.

The Bureau can publish the results of its work, such as the Class I Inventory to add to the literature on Oregon history. Bureau contracts could stipulate completion of a general, informational report in addition to more technical, management-oriented reports. To continue to gather information at public expense without public benefit is not the intent of cultural resource management. Such works could also be used in the public schools and by Native American groups.

The Bureau should fund the construction of either temporary or permanent museum displays based on the regional history of the District. Artifacts collected from Bureau 
lands within a District, now in storage at the universities, could be used to create such displays. This, again, provides an opportunity for public service and education. It would counter the current feelings that artifacts are taken from the community never to be seen again.

It is also recommended that the Bureau produce films for public television programs on protection of cultural resources.

The Bureau should make the time and funds available to the Districts to photograph, catalogue, and write a narrative description of the major amateur collections in each District. Currently, any information gathered from this is on a piecemeal basis. If these collections are not recorded before they are sold, lost, or broken up, valuable information will be lost to the District. In addition, an opportunity to allow collectors to make a contribution to the total knowledge base, while including a chance to educate them, will be lost. It is discouraging to know that information offered by a collector has been refused by the archeological community. Possibly, the District cultural resource specialist can work at opening lines of communication with the collector.

The Bureau should require that archeologists working on Bureau lands make regular news presentations to the community through the local news media. It appears unlikely that the archeologists would initiate such an activity. 
The archeological community's attitude that they are paid to do archeology not talk to people could be altered by contract requirements. If the Bureau could work such public education-oriented items into its list of technical requirements, as a part of the things which must be accomplished rather than a part of the things the Bureau may want accomplished. (Wildesen 1979), then these things can indeed be accomplished.

\section{Archeologists Contributions}

The archeological community must realize that they can not continue to ignore the public. Chapter II presented the public's images of the archeologist. These images must be changed. While the Bureau can require contract work be done on behalf of the public, the archeologists should take the initiative to correct their own image.

Time and some money should be put into public relations work. Archeologists should seek to involve the avocational archeologist in their programs.

The collections of artifacts which are held by the universities should be catalogued and made available for displays.

The results of all research should be made available to the public as soon as the work is completed. 
expanding field involving archeology, history, architecture, and anthropology. Many of the skills which are needed by the District cultural resource specialist could be improved, brought up-to-date, or kept current by providing special training. Those skills which a District cultural resource specialist does not have could also be provided.

It may be possible to develop training sessions inhouse by the Denver Service Center, to arrange for sabbatical leave to attend a university, to hire university faculty for inhouse training, or to arrange a correspondence type of training. Subjects could include history, paleontology, ehtnography, oral history, and architecture.

There is no reason why training should be limited to cultural resources. There would be benefit to the cultural resource management program if training were received in such fields as aerial photography and remote sensing application, range management, forest silviculture practices, and contracting: The more the District cultural resource specialists know about other programs, the better they will be able to predict impacts and to integrate their program with others. By the same token; land use managers and other Bureau employees would benefit from some formal training in cultural resources.

The Bureau should provide subscriptions and memberships to the pertinent publications and organizations which deal with cultural resources. New major publications 
should be purchased for reference library materials. This is done on a limited basis currently and policy varies from District to District.

Many new ideas, research proposals, useable data, etc., are presented in papers. at society meetings. Meetings also provide a direct line of communication to other cultural resource personnel. They provide a forum for presentation of major problems. It would be in the best interest of the Bureau if it would cover the cost of attending such meetings. Currently, there are generally no funds available on a regular basis.

The concept of training for or development of a degree in cultural resource management should be based upon the need that there be two types of archeologist: the researchoriented archeologist who uses the resource, teaches, does research, or provides contract services and the cultural resource management archeologist or specialist whose primary duties are to see that the cultural resources are protected and managed for best use.

While these are interchangeable roles, they are not mutually inclusive nor are all persons suited for both. The primary reason why some archeologists have left the Bureau for university positions or other jobs is the desire to be involved more in archeological field work and research. Some have also displayed discomfort working in a bureaucratic situation. 
The person trained in archeology coming from the university is not prepared to handle the task of cultural resource management and has much to learn on the job.

It has been suggested that all a person working for , an agency needs to have. is a good background in archeological theory and that "real-world skills" can be gained on the job (Schiffer and Gumerman 1977:14). Such a concept is highly biased and counterproductive to the development of a true cultural resource management program. It considers only the archeological aspect of cultural resource management. The land use manager who hires an archeologist to do cultural resource management work has a right to expect the person to be capable of doing the full job, not just the archeological aspect of it. While it is true that much in the way of organization, daily operations, etc., will have to be learned on the job, there is basic training and knowledge that should be brought to the job. What then should be involved in a cultural resource management training program?

The person coming into cultural resource management work should have a solid theoretical background in archeology. This should involve all phases of archeology, historic and prehistoric, from initial field survey, laboratory analysis, to publication of a final report. It is quite probably that the cultural resource management specialist will be called upon to perform or at least know about all 
phases of archeology at least for contract administrative purposes.

The person desiring a position in cultural resource management should have background in the cultural resource management literature. In the last few years, a large body of information has been published on the subject which should be required reading. In addition, a basic understanding of existing cultural resource management programs at the State and federal level is essential. Coursework in American government is recommended.

There is a need for the cultural resource specialist to have skills in land use planning and environmental assessment. Other skills would include the earth sciences, in such areas as range management, geology, and botany, history, oral history, ethnography, architecture, and paleontology. There is need for skills in administration, budgeting, contract proposal development, and contract administration.

It is recommended that the universities develop a degree program in cultural resource management incorporating the aforementioned skills. Such a program should be incorporated under the anthropology departments since there should be an emphasis on archeological training as archeological sites are the most common and difficult of the cultural resources to manạge.

Training for cultural resource management work must 
be more than a quick review of the laws and contract proposal writing. The Bureau could become involved in cultural resource management training through internships. Theses and dissertations could be developed on management and preservation practices. These could involve Bureau lands and/or projects as test cases.

\section{CONTRACTING}

A great percentage of the cultural resource work which is done by the Bureau in the future will be by contract. Archeologists will continue to be the principal contractors for these contracts for a number of reasons. While it is true that cultural resource management encompasses more than just archeology, the Bureau has placed the most emphasis on archeological resources. Archeologists have been asked to provide most of the cultural resource management data. This is due to a number of factors. (1) Archeological sites are the most common type of cultural resource on public lands. (2) They are the least understood by Bureau land use managers and the most difficult to manage. (3) Archeologists have been the most vocal proponents of cultural resource management and protection. (4). A new and somewhat misunderstood program, such as cultural resources, is not likely to get adequate Bureau funding for inhouse staffing. (5) The feeling prevails among archeologists and Bureau land use managers that archeologists should 
know about, or at least be capable of dealing with, other types of cultural resources.

There are a number of problems with these assumptions. The archeologists have not displayed a complete understanding of cultural resource management, archeologists have tenced to be more interested in doing archeological research than management, archeologists are not necessarily capable of completing work in all aspects of cultural resource management, and archeologists as contractors may fail to provide meaningful management recommendations.

Many archeologists recognize that cultural resource management is more than just archeology.

Cultural resource management is properly concerned with all sorts of cultural resources, including not only archeological sites but historic buildings and districts, social institutions, folkways, arts, crafts, architecture, belief systems, the integrity of social groups, the ambiance of neighborhoods, and so on (McGimsey and Davis 1977:27).

While the archeologist may recognize these differences in principle, they must be careful to actually include them in their contract work. If they can not address all of the cultural resources, then archeologists should address themselves to that part of cultural resource management with which they are comfortable and leave the rest to other specialists. It will no longer be acceptable to contract for a cultural resource management study and consider only archeology or history. The land use managers are becoming more aware of the needs for more than archeology in cultur- 
al resource management.

Archeologists have been mainly concerned that cultural resource management work produce archeological research which meets current acceptable research standards. The participants of the Airlie House seminars on cultural resource management held in 1975 represent this trend of thought.

It was the strong feeling of all the seminar participants that all archeological activity, however funded, must be conducted and evaluated in the light of sound scientific principle and with a concern for appropriate conservation of the total resource base (MCGimsey and Davis 1977:26).

The literature contains many references to the need for contract work or cultural resource management type work to be of good archeological quality (e.g. King et al. 1977, Schiffer and Gumerman 1977). It is also recognized that there are differences between cultural resource management archeology and traditional research archeology (McGimsey and Davis 1977:26). These differences are said to be basically those of choice of research area selection, choice of sites to be examined, constraints of time for preparation of a report, and the development of management recommendations (McGimsey and Davis 1977).

Given the system for cultural resource management which the Bureau has developed, there should be little fear that good archeological research can not be carried out and indeed has been (King et al. 1977, Schiffer and Gumerman 1977)' 
The concern from the Bureau's standpoint is that during the course of these same cultural resource management studies, that good cultural resource management work also be performed. The matter dwells on whether cultural resource management is to be cultural resource management for archeology or whether it will be archeology for cultural resource management. The two are not mutually inclusive. The literature has many references to doing good research in cultural resource management (e.g. King et al. 1977, McGimsey and Davis 1977, Schiffer and Gumerman 1977). What it lacks is good information on how to do cultural resource management and to provide the land use manager with the tools to complete his tasks. This is not to say that the total needs of land use managers have been neglected, rather they have not always been fully addressed.

Archeologists must enter contracts with the attitude of how to best help the land use manager preserve and protect cultural resources by doing the best archeology possible rather than how can this contract produce the best archeology possible. In each case, it is possible and probable that good archeology will be a product. In the first case, good resource management is also likely to be accomplished.

The completion of significance evaluations and making management recommendations are the most vital parts of a cultural resource contract. Archeologists must make a 
concerted effort to properly address these parts of the contract. A majox part of the contract report should be devoted to these subjects. It should be readily available to the land use manager as a separate segment of the report, probably located in the very front of the report as has been suggested by Macleod (1977:69). This part of the report should be written in a form which can be understood by the land use manager. Technical terms should be avoided.

The management section of a report should summarize the findings of the contractor. The contractor must make concrete, sound recommendations. Those sites which are judged to be significant, as well as those judged to be insignificant, must be supported by rational arguments. It must be explained and documented as to why this decision was made. Recommendations for management must also be rational, documented, and most of all, explained for the land use manager. If research designs, new techniques, physical protection, is recommended or needed, the contractor must fully explain the how and why of such recommendations. If there is a situation where a contract concludes that evaluations of significance and management recommendations can not be made, the contractor must recommend more than something to the effect that more work needs to be done. The management recommendations should explain why more work must be done and what that work would involve. 
The contractor should be able to estimate the benefit of his recommendations to cultural resource management. The cost of implementing all recommendations must be provided.

In addition, it is the contractor's duty to complete all contract stipulations and to provide it on time.

The Bureau must also take responsibility to attempt to improve contracting. This can be done by careful development of the desired needs in the contract proposal. The Bureau must develop its program in such a fashion that all contracting is designed to fit into a regional design as has been suggested.

One potentially important approach to the integration of the profession's research needs and the sponsor's management and legal compliance needs, is the development of research priorities and overall research design on a regional basis (McGimsey and Davis 1977:29).

The Contracting Officer's Authorized Representative (COAR) must insure that the basic needs of the cintract are met before accepting the final report.

It is suggested that the Bureau sponsor a statewide seminar on contracting. Such a seminar could detail all the parts of contracting, including language, the legal requirements, the problems, and the goals. The seminar would foster interaction on major problems and initiate communication.

In addition, the Bureau should provide training in contract administration to its cultural resource spe- 
cialists.

OTHER RECOMMENDATIONS.

Research by the Bureau

The Bureau's cultural resource management program does not permit research unless it can be demonstrated that it will improve management. As has been pointed out, a certain amount of research is required for completion of management objectives. Research, as an end in itself, is prohibited.

There exists great potential for the Districts to conduct good, nonconsumptive research if given the time and money. The Bureau should recognize the need for such work and the potential benefits to the program. Just as the universities need to recognize that cultural resource management work is worthy of reward, the Bureau needs to recognize research as worthy of the time and money required to accomplish it.

\section{Cultural Resource Assistants}

The District cultural resource specialist frequently has more survey work than can be accomplished. The annual work plan limits funds so more personnel can not be hired unless special funding can be obtained. One method of obtaining assistance, which the Bureau has used, is the cultural resource assistant. Persons are trained to recognize sites and record them. These persons can be assigned to do the initial and/or complete cultural 
resource survey on a project. The control for this inventory work is that the District or state cultural resource specialist must concur with the report. The assistant can not give project clearance nor can he evaluate the significance of any located sites.

There are advantages and problems with the assistant approach .

Let us examine the advantages. The number of project clearances required in a given fiscal year may be such that the cultural resource specialist can not look at everything. Some proposed projects have probably minimal impact or are in areas of past disturbances. The use of assistants to look at smaller, less disturbing projects allows use of the cultural resource specialist's time on other projects.

Secondly and possibly most important, such an approach can and does foster cultural resource awareness in Bureau employees.

What then are the disadvantages? First, the level of training is such that sites may be missed or not reported because they did not look important. A legal consideration is if only a professional has the legal ability to state an area is clear of cultural resources.

Secondly, the personnel within such a program may by intent, fail to disclose the location of a site at a project which they themselves may have designed or that they believe should continue. The cultural resource specialist normally 
would not have supervisory control over these assistants. There is potential that the assistants may interject their own beliefs or values on an inventory. They may not report a lithic scatter as a site because they see them throughout their area and do not feel them to be important. Collectors may become assistants. If one collects, what better way to find sites and artifacts then to get sent looking for them.

The best solution for using such an approach is to use it only as a last resort.

Training is essential. The employees involved should receive enough formal training to be considered technicians. This should involve some level of classroom work, attendance at field schools, and regular refresher training. This type of program could be equated to Bureau programs such as range technicians or forest technicians. It may be that the Bureau would want to hire persons already trained at this level. The program could be designed to employ these individuals fulltime as cultural resource technicians rather than using employees from other fields.

\section{Study of Impacts}

Many of the types of Bureau undertakings create impacts to cultural resources which are not easily determined. These include such things as livestock grazing, vegetation manipulation, grass seedings for livestock, and logging. 
There is a clear need to undertake studies to determine the nature and extent of such projects to cultural resources. Without such data, preparation of environmental statements can not properly analyze impacts to the resource. The Bureau could either undertake such projects inhouse or contract for the work. There is a possibility that such research could be used as a thesis project in a cultural resource management program.

\section{Refusal to Consider Cultural Resources}

While there are specific laws regarding cultural resources which the Bureau has interpreted in policy for the preservation and protection of cultural resources, there always exists the possibility that a land use manager will through benign neglect or direct course of action fail to take cultural resources into consideration during the planning process or during implementation of a Bureau undertaking.

If a situation of noncompliance is found to exist within the District by the cultural resource specialist, what course of action can be taken? The chain of command specifically implies that the cultural resource specialist can go no further with his concerns than the District Manager who is his boss. If the situation is not remedied by appeal to the District Manager (or if the District Manager is responsible), what can be done? The cultural resource specialist is faced with an ethical dilemma. 
Should he notify the State office or someone outside the Bureau, such as the State Historic Preservation Office, or should he feel he has met his obligation by seeking remedy through the District Manager?

The only course of action is to report the action after advising the District Manager that there is a moral obligation to report the situation. Once the situation has been brought to the attention of the proper authority, remedy can be sought under 36 CFR 800 to have the proper planning procedures completed along with the necessary compliance checks.

\section{Collecting by Bureau Employees}

In the past and still today, it has often been said that the Bureau employee, and the federal employee in general, is one of the most destructive and most frequent artifact collector (Chance 1968). This problem has been used as a reason why the Bureau should not be giren site location information and should be discouraged from cultural resource management. However, at the same time, the archeologist protests and laments the loss of sites to Bureau project activities. The Bureau, in order to eliminate its destruction of sites by project activities, must be aware of archeological site locations within a project area so protection (or salvage) can be planned. The Bureau must address the problem of collecting by its employees in order to accomplish the goals of its 
cultural resource management program. This can be accomplished in two ways: threat of job disciplinary actions or by creation of awareness and appreciation of the resource. Bureau policy directs that employees shall not collect any objects of antiquities on federal lands or in any other way cause intentional damage to them or disciplinary action is to be taken. This policy is best reserved as a last resort. The resourceful collector will find a way to collect without being caught. Private lands hold many prime sites.

More results will probably be obtained by getting the employee on the side of the archeologist, to make it nondesirable to collect. This can be accomplished through the actions of both the Bureau and the non-federal archeologists. The Bureau should prepare and present regular employee orientations on the value and meaning of cultural resources. Orientation should explain the laws and Bureau policy regarding cultural resources. The nonfederal archeologists should direct some of their time to the Bureau employee. A stop at the local office to chat with knowledgeable and concerned employees would do a lot to foster concern and goodwill. The local employees should be invited to view and to help in cultural resource projects within the District. It may often be the case that other District employees can provide services, such as geology, biology, soils, to the archeologist. The 
results of any work in the District should always be reported to the local employees (as well as the community at large) in the form of a talk, display, or publication.

Preparation of Environmental Statements

The Bureau is responsible for the preparation of environmental statements for its undertakings. To insure proper consideration of cultural resources, this section of the environmental statements must be prepared by the cultural resource specialist. If the report is prepared by a writer/editor, the specialist must be given an opportunity for final review to correct any deficiencies in the cultural resource section of the statement.

The Bureau must make sure that all necessary data is available for preparation of statements. This includes inventory and potential impact analysis.

The statement must be made available during all planning stages to the State Historic Preservation Office, archeologists, historians, and anthropologists. Review by concerned parties can be assured by requesting to be on the Bureau's review mailing list and by requesting to be notified of Bureau undertakings which will require environmental statements. The State Historic Preservation Office should be sent a review copy of all statements under the A-95 clearinghouse process. The review of statements is a time consuming task and one individual probably can not review more than a few statements during 
the course of a year. It is recommended that the AOA set up a committee for review and comment to the Bureau.

\section{Law Enforcement}

The threat of destruction of cultural resource sites by artifact collectors is one of the major proplems facing the Bureau. Presently, there is little law enforcment officer-type capability within the Districts.

The basis for cultural resource protection has been the 1906 Antiquities Act. This law has had very little use and recently has come under threat of not being useable at all (Grayson 1976, Collins and Green 1978). While new legislation has been proposed to update the 1906 law and make it more effective (Collins and Green 1978), this does not alleviate the present situation.

Fortunately, the Bureau has other legal recourses for the protection of cultural resources.

The Federal Land Policy Management Act prcvides, as was discussed earlier, for penalties when persons on federal lands do not follow rules of conduct while on those public lands. The Bureau can also issue and enforce rules pertaining to the protection of cultural resources. There is also the possibility that a person who removes artifacts from sites or destroy sites can be charged with theft or destruction of government property.

Any of these measures can be used for prosecution of antiquities violations. In fact, theft of government 
property has been used successfully for such prosecutions in Oregon and Idaho (Diech 1978, Friedman 1978).

It may also be possible to use the Oregon State antiquities and burial laws for prosecutions on federal lands (Walker 1979).

The Bureau must first apprehend violators in order to bring them to court. At the present time, the only patrol work which the Bureau does in oregon is that of the District personnel and when available the State's two law enforcement personnel. The patrol of lands for cultural resource violations can be the responsibility of all Bureau employees, yet only those directly connected with the cultural resource management program are going to care or have the time to report possible violations. Essentially, this means the District cultural resource specialist and three or four assigned cultural resource technicians are available to patrol the District in addition to regular duties. Further, these Bureau employees who may make contact with collectors are not trained in law enforcement techniques, have no legal authority other than that of the average citizen, and often may be placed in a threatening situation. The Bureau employee who approaches a collector is not regarded as doing his job, in most cases, but rather is thought of as a typical bureaucrat, harassing the citizen. It is a difficult and tense situation at best. If the Bureau employee observes 
a possible violation, he is limited to collecting all available information regarding the violation and referring it to the proper authority. Employees are cautioned by the Bureau that they can be subject to civil suit, if overzealous, and that the Bureau can not pay any judgments against them. Such a situation is not going to encourage employees to pursue possible violations of antiquities laws.

There are a number of ways in which the Bureau can begin to address this problem. First, the Bureau should increase their inhouse legal capability with additional fulltime law enforcement officers or with ranger type positions with some limited legal capability.

Secondly, the Bureau can contract with local law enforcement agencies for cooperative law enforcement patrols on federal lands as provided for by the Federal Land Policy Management Act and specifically seek antiquities violations.

In addition, the creation of a warden system could help report violations to the proper authority for action.

\section{Inventory Procedures and Inyentory Storage}

The management of cultural resources by the Bureau is in many ways dependent upon the completion of an inventory of that resource. The Bureau has specifically set about the process of inventory. The problem lies in the magnitude of the situation because of the amount of public 
lands. Granting that 100 per cent of the land mass does not have to be examined because of the unlikelihood of sites being located on sheer 1000' cliffs, for instance, probably 10,000,000 acres of the 15,000,000 acres of Bureau administered lands in the state should be examined. The present criteria for a Class III Inventory is that transects of 30 meters or less be walked over the land. The average person will cover about 120 acres in one day. This would require 83,000 person days or 4,150 months or about 345 years just to do an intensive inventory. It would be unreasonable to expect such a task to be accomplished overnight. In terms of potential cost, in 1978, the average contract cost per survey acre was five dollars. To survey $10,000,000$ acres would cost $\$ 50,000,000$ for just basic inventory without any preservation or management work. Clearly, if total inventory happens at all it will have to be over a period of many years. If the funds were made available, there would not be enough archeologists and historians available to complete this type of inventory. It also appears to the author that while this type of information is essential for cultural resource management planning on a regional basis, it will not be accomplished in the foreseeable future and will benefit archeology more than cultural resource management. For realistic purposes, the Bureau needs to survey for the rare elements and more importantly those areas of immediate 
potential Bureau impacts. This would serve better the needs of cultural resource management; while at the same time, continuing its systematic surveys. This would better serve the needs of cultural resource management by including the rare types of sites which might be lost in strictly random surveys and allow prior planning for cultural resources on upcoming Bureau projects.

The Bureau must also make future plans for the storage of inventory data. Plans should be made in conjunction with those of the universities.

The available site data in oregon has for years been kept on needle sort cards at the Museum of Anthropology, University of Oregon. This system is cumbersome, time consuming; and limited in capability. It is hard to record all types of site data, content of reports, location of reports, site collections, excavation collections, and private collections. Probably no compilation exists in one place in oregon of total data held by the universities, museums, and individuals. If a researcher wanted to locate the total known resource base of sites located at $5000^{\prime}$ elevation in a given environment that contained projectile points from 7000 to 5000 B.P., under the present system this would be extremely difficult to accomplish. Oregon clearly has the need for a more modern, faster, and useable system of data storage. The only type of system that can reasonably bring all information together and make 
it easily available to those needing it is the use of a computer.

The Bureau and U.S. Forest Service in Oregon are in the process of making Automated Data Processing systems operational. Both are in the process of designing a system to handle cultural resource information. The state of Oregon would be wise to attempt to gain access to the cultural resource segment of these systems in a cooperative agreement basis for storage of Oregon's cultural resource data.

While these systems are in the initial stages, all parties concerned would be wise to examine the ADP system already developed by the Provincial Museum of British Columbia for recording of artifacts, site reports, excavation data. This system was devised to provide the Museum with a system for orderly cataloguing and easy retrieval of cultural resources data.

One of the most useful features of the modern retrieval system is the ability to extensively and rapidy manipulate the catalogue record items at a very low cost. This permits, and actually encourages, the use of the collection for research and makes the task of maintaining the efficient and safe storage of the objects much easier (Loy and Powell 1977:1-2).

The ability of Oregon to develop a regional overview will depend upon access and ability to manipulate the basic cultural resource data currently scattered throughout the state. It is hard to conceive of anyone being able to accomplish a compilation of existing data without resorting 
to the use of a computer.

It would be reasonable to assume that all of the universities, agencies, and professional cultural resource workers would have access to the stored data. Security of the data can be gained by careful control over access systems to the data. It would be no more difficult than access protection for the present storage system. The argument that the data can not be protected if placed within a computer system is not a valid argument.

It has been argued that the cost to implement such a system would be prohibitive. The actual cost of such a system is directly related to the number of subscribers to the system and the size of the body of data to be put into the system. The more uses that are made of a system, the lower the cost per entry. The rapid increase in site inventory, excavation collections, research reports, etc., will quickly burden the capability of present systems. The body of existing cultural resource data is already extensive. The systems being designed by the Bureau and U.S. Forest Service are already available, the cost will be mostly carried by other resource uses. If a cooperative agreement can be made with the state of oregon for inventory storage, the cost should not be prohibitive. Once the initial conversion has been made to an ADP system, upkeep should be minimal as new data is submitted.

The usefulness and manageability of such a system will 
in many ways depend upon the ability of the cultural resource management professional to use the system. There would be a need for training in the uses of an ADP system to enable use at its full potential.

\section{Cultural Resources As a Separate Resource}

There is a general trend in the Bureau to some extent to not fully consider cultural resources as a resource that should be managed. It must be remembered that most of the Bureau's management personnel have been with the agency for more than 15 years. It has only been in the last 5-10 years that any real effort has been made to consider the resource and the last five years that a program developed. What in the past was not important now is required.

There is an additional problem in that cultural resources still are not a fully implemented program. Most of the work that is done is in support of other activities. The cultural resource management program is located within the recreation program and potentially must serve that resource. Funding must be obtained under support needs and the recreation program.

It is recommended that cultural resources be separated from the other programs and established within the Bureau organization as a single resource with its own programs. This would recognize cultural resources in their own right which the land use manager would be responsible to manage. 
The National Register

The National Register has been described as a planning tool for preservation of cultural resolurce sites. Yet, there is widespread disagreement even on the application of the criteria under which a site may be eligible for the National Register. There is also widespread feeling among the public and the land use manager that National Register nomination will eliminate their control over properties nominated. Yet, the National Register is central to the whole process of cultural resource management as mandated through the National Environmental Policy Act, the National Historic Preservation Act, Executive order 11593, and 36 CFR 800. The process for nomination is confusing and difficult. The nomination of a property must be based upon a defensible argument of its value more than its existence (King 1977). At the same time, it may become increasingly difficult for sites to be determined ineligible for the Register. It requires as much documentation and thought to show that a site does not have research value as to show that one does.

It must be realized that all sites can not be listed on the National Register. At the same time, it should not be limited to the biggest and best. It is suggested that the Bureau's representative sample of sites for preservation be nominated to the National Register for preservation planning. 
The preservation aspect of the National Register may also lie in the nomination of districts and regions and designing for preservation of all sites within them, in effect, cultural resource preserves. The wilderness areas by design may end up being such areas.

There needs to be work also on the way in which sites are nominated. The nomination of sites to the National Register has become a stumbling block to many. While the National Register is at the heart of cultural resource management programs, it is little understood. The reasons for the Register, the criteria for nomination, and the use of the Register is confusing at best. The shear size of the nomination. form, the required data, and the time required to prepare and carry out a nomination is prohibitive. If the requirements of nomination are closely followed, only archeologists and historians will be able to complete the procedure. This is unfortunate because the layman may recognize a potentially significant site, but not be able to provide the necessary data for a nomination. Not every federal office, state office, and certainly interested layperson, will have good access to professional help in preparation of nominations.

Because of the vague nature of the criteria for a potential National Register site, it could be argued that all sites have potential. It is the author's opinion that all sites on Bureau lands should be considered as potential 
for inclusion in the National Register until such time as a good sample inventory has been completed.

The nomination procedure for National Register sites should also be revised. The forms and instructions should be designed in such a fashion that anyone can fill them out. It might also be possible to arrange for a prenomination process where sites are brought to the attention of the proper authority. If it can then be determined that the site has good potential, then a professional archeologist or historian could complete the nomination. It would also be helpful if a training seminar could be arranged for the State based upon the National Register nomination process.

\section{SUMMARY}

The Bureau of Land Management has developed a systematic approach to management of cultural resources which is based upon laws enacted over the last 70 years. There are problems inherent to the program and its relationship to the archeological community. Many of these problems can be solved through communication and cooperation. It is hoped that the solutions presented here will be examined by the Bureau and by the archeological community and will be initiated in an attempt to solve the problems. 


\section{SELECTED BIBLIOGRAPHY}

Books, Periodicals, and Other Iiterature

Agogino, George A.

1960 The Need for More state and Federal Aid for Paleo-Archaeology in the United States. New World Antiquity $7(2): 20-23$.

Agogino, George A. and Sally Sachs

1960 Criticism of the Museum Orientation of Existing Antiquity Laws. Plains Anthropologist 5.(3):31-35.

Aikens, C. Melvin

1976 Some Archeological Concerns of the Bureau of Land Management in Oregon: observations and Recommendations. On file Bureau of Land Management, Oregon State Office, Portland, Oregon.

American Anthropological Association

1973 Professional Ethics, Statements and Procedures of the American Anthropological Association. AAA, Washington, D.C.

Ascher, Robert

1960 Archaeology and the Public Image. American Antiquity 25:402-403.

Ayres, James E.

1975 Cultural Values in the wilderness: The Historical Perspective. In The Wilderness and Cultural Values: A Symposium, edited by Dee F. Green, Archeological Report No. 7:30-38. USDA Forest Service, Southwestern Region.

Beals, Ralph L.

1971 Traffic in Antiquities. American Antiquity $36: 374-375$. 
Beckham, Stephen Dow

1978 Identifying and Assessing Historical Cultural Resources in the Pacific Northwest. USDA Forest Service, Pacific Northwest Region, Studies in Cultural Resource Management No. 2.

Borchard, Lucinda and Don D. Fowler

1975 Preliminary Bibliography on Conservation Archeology and Cultural Resources Management. Desert Research Institute, University of Nevada, Reno, Nevada.

Bumsted, M. Pamala

1978 The Use and Misuse of Archeology. Anthropology News letter 19(3):14-15.

Carstensen, Vernon (editor)

1962 The Public Lands. University of Wisconsin Press, Madison.

Chance, David $\mathrm{H}$.

1968 Survey of Antiquities Management on Bureau of Land Management Lands in Oregon 1968. On file Bureau of Land Management, Oregon State Office, Portland, Oregon.

Chapman, Carl H.

1978 A New Home for Archaeology in the Federal Government. Archaeology $31(4): 58-59$ :

Clary, David A.

1973 Preserving the Environment: Participating in the Review Process. American Association for state and Local History Technical Leaflet 8 . History News $28(2): 29-36$.

Clewlow, C. William, Jr.

1973 Private Enterprise and the Crisis in American. Archaeology: Kroeber Anthropological Society. Special Publication No. 3.

Clewlow, C. William, Jr., Patrick S. Hallinan, and Richard D. Ambro

1971 A Crisis in Archaeology. American Antiquity $36: 472-473$. 
Clifton, James A. (editor)

1968 Introduction to Cultural Anthropology. Houghton Mifflin, Boston.

Cole, John $\mathrm{R}$.

1973 Pot Hunting. The Rape of America's Past. Popular Archaeology 2(10):32-34.

Collins, Robert Bruce and Dee F. Green

1978 A Proposal to Modernize the American Antiquities Act. Science 202(4372):1055-1059.

Corson, Christopher

1977 The Desert Countryside in the Wake of the Beasts. Some observations on the Quality of Environmental Data in the Northern Great Basin. Paper presented at the 1977 Meeting of the Society for California Archaeology, San Diego.

Cotter, John L.

1974 Above Ground Archaeology. U.S. Government Printing Office, Washington, D.C.

Davis, Hester A.

1971 Is There a Future for the Past? Archaeology 24. (4):300-306.

1976 The Public and Cultural Resource Management: Reaction and Responsibility. In Symposium on Dynamics of Cultural Resource Management, edited by Ray T. Matheny and Dale I. Berge, Archeological Report No. 10:50-54. USDA Forest Service, Southwestern Region.

Dekin, Albert A., Jr.

1971 Anthropology and the Public. Anthropology Newsletter. $12(9): 2$.

Deming, $\mathrm{O} . \mathrm{V}$.

1957 The Antiquities Laws and You. Desert Magazine, November: $17-20$. 
Diech, Lyman

1978 Personal communication regarding Antiquities Act violation on Bureau lands in the Medford District.

Dixon, Keith A.

1971 Archaeological Site Preservation: The Neglected Alternative to Destruction. Pacific Coast Archaeological Society Quarterly 7(4):51-70.

Dunnell, Robert $C$. and William S. Dancey

1978 Assessments of Significance and Cultural Resource Management plans. American Society for Conservation Archaeology News letter 5(5):2-7.

Ferguson, Bob

1972 New Roles for the Amateur Archaeologist. American Antiquity $37: 1-2$.

Fleming, Ronald Lee

1971 After the Report, What?: The Uses of Historical Archaeology, A Planner's View. Historical Archaeology 5:49-61.

Forness, Norman 0 .

1976 Creation of the Department of the Interior. Historical Vignettes 1776-1976. Office of Communications, Department of the Interior, Washington, D.C.

Fradkin, Philip L.

1979 The Eating of the West. Audubon 81(1):94-121. Friedman, Janet

1978 Personal communication regarding Antiquitites Act violations on U.S. Forest Service lands in the Hells Canyon recreation area.

Goodyear, Albert C., I. Mark Raab and Timothy C. Klinger

1978 The Status of Archaeological Research Design in Cultural Resource Management. American Antiquity $43: 159-173$. 
Grayson, Donald $\mathrm{K}$.

1976 The Antiquities Act in the Ninth Circuit Court: A Review of Recent Attempts to Prosecute Antiquities Act Violations in oregon. Tebiwa $18(2): 59-64$.

Green, Dee F. (editor)

1975 The Wilderness and Cultural Values: A Symposium. USDA Forest Service, Southwestern Region, Archeological Report No.?.

Green, Harold P.

1973 The National Environmental Policy Act In The Courts (January 1, 1970-April 1, 1972). The Conservation Foundation, Washington, D.C.

Gumerman, George J.

1973 The Reconciliation of Theory and Method in Archeology. In Research and Theory in Current Archeology, edited by Charles L. Redman, pp. 287-299. WileyInterscience, New York.

Hallinan, Patrick S.

1973 Archaeology and the Law. In The Crisis in North American Archaeology, edited by Allen C. Pastron, Patrick S. Hallinan, and C. William Clewlow, Jr., Kroeber Anthropological Society, Special Publication No. 3:5-24.

Heizer, Robert F.

1966 Salvage and Other Archaeology. The Masterkey. $40(2): 54-60$.

1974 A Question of Ethics in Archaeology - One Archaeologist's View. Journal of California Anthropology 1(2):145-151.

Hester, James $\mathrm{J}$.

1963 A Training Program for Salvage Archaeology. American Antiquity 28:392-394.

Hester, James J., John Musik and Marvin Woolf

1973 Archaeology and the Law. Missouri Archaeologist $35(1-2): 5-19$. 
Hewett, Edgar L.

1904 Government Supervision of Historic and Prehistoric Ruins. Science 20(517):722-727.

1905 Preservation of Antiquities. American Anthropologist $7(3): 164-166$.

Howe, Carrol B.

1968 . Ancient Tribes of the Klamath Country. Binfords and Mort, Portland, Oregon.

Jennings, Jesse D.

1963 Administration of Contract Emergency Archaeological Programs. American Antiquity 28:282-285.

Johnson, Elden

1973 Professional Responsibilities and the American Indian. American Antiquity 38:129-130.

Kee1, Bennie C.

1979 A View From Inside. American Antiquity 44:164-170.

King, Thomas F.

1971 A Conflict of Values in American Archaeology. American Antiquity 36:255-262.

1973 Mitigation of Mammoths in California and Other Bizarre Stories. Missouri Archaeologist 35(1-2): 32-35.

1974 Syllabus for U.S. Forest Service Archaeological Training Course, Region 5. Sequoia National Forest. Sequoia National Forest, Hot Springs, California.

1.976 Public Archaeology: New Horizons or Shrinking Perspectives? Paper presented at the American Anthropological Conference, San Francisco.

1977 More on Cultural Resource Management. Current Anthropology $18(4) ; 749-750$.

1978 The Archeological Survey: Methods and Uses. U.S. Department of the Interior, Heritage Conservation and Recreation Service, Washington, D.C. 
n.d. On the Recruitment and Training of "Public Archaeologists". Unpublished manuscript.

King, Thomas F., Patricia Parker Hickman, and Gary Berg

1977 Anthropology in Historic Preservation. Caring For Culture's Clutter. Academic Press, New York.

King, Thomas F. and Margaret M. Lyneis

1978 Preservation: A Developing Focus of American Archaeology. American Anthropologist 80:873-893.

King, Thomas F., Michael J. Moratto, and $\mathrm{N}$. Nelson Leonard III

1973 Recommended Procedures for Archaeological Impact Evaluation. Society For California Archaeology, Los Angeles.

Lahren, Larry A.

1977 More on Cultural Resource Management. Current Anthropology $18(4): 750-751$.

Lee, Ronald F.

1970 The Antiquities Act of 1906. U.S. Department of the Interior, National Park Service, Office of History and Historic Architecture, Washington, D.C.

Lipe, William D.

1974 A Conservation Model for American Archaeology. The Kiva 39(3-4):213-245.

1975 The Wilderness System and Archeological Conservation. In The Wilderness and Cultural Values: A Symposium, edited by Dee F. Green, Archeological Report No. 7: 7-21. USDA Forest Service, Southwestern Region.

Longacre, William A. and R, Gwinn Vivian

1972 Salvage Archeology, Science (178(4063):811-81.2. Loy, T. and G. R. Powell

1977 Archaeological Data Recording Guide. British Provincial Museum Heritage Record No. 3. Victoria, British Columbia. 
Macdonald, William $\mathrm{K}$.

1977 More on Cultural Resource Management. Current Anthropology 18(4):751-752.

Macleod, Donald G.

1977 Peddle or Perish: Archaeological Marketing from Concept to Product Delivery. In Conservation Archaeology. A Guide For Cultural Resource Management Studies, edited by Michael B. Schiffer and George J. Gumerman, pp. 63-72. Academic Press, New York.

Marshall, Larry $G$.

1976 Paleontological Salvage and Federal Legislation. Journal of Paleontology $50(2): 346-348$.

Matheny, Ray T. and Dale L. Berge

1976 Some Problems Pertaining to Cultural Resource Management. In Spmposium on Dynamics of Cultural Resource Management, edited by Ray T. Matheny and Dale L. Berge, Archeological Report No. 10:1-8. USDA Forest Service, Southwestern Region.

McGimsey, Charles R., III

1972 Public Archeology. Seminar Press, New York. McGimsey, Charles R., III and Hester A. Davis (editors)

1977 The Management of Archeological Resources: The Airlie House Report. Special Publication of the Society for American Archaeology, Washington, D.C.

McKinney, Charles M.

1976 Cultural Resource Planning in Federal Project and Land Management Activities. In Symposium on Dynamics of Cultural Resource Management, edited by Ray $T$. Matheny and Dale L. Berge. Archeological Report No. 10:24-32. USDA Forest Service, Southwestern Region.

Moore, Earl F.

1977 Sizent Arrows, Indian Lore and Artifact Hunting. Paul Tremaine, Klamath Falls, Oregon. 
Moratto, Michael J.

1975 Conservation Archaeology: A Bibliography. Conservation Archaeology Papers No. 1. San Francisco State University, Archaeological Research Laboratory.

Moratto, Michael J., Lawrence Aten, Vernon Bellecourt, Joe Brecher, Charles R. McGimsey, III, Marvin Woolf

1977 A Consideration of Law in Archeology. In The Management of Archeological Resources: The Airlie House Report, edited by Charles R. McGimsey, III and Hester A. Davis, pp. 8-24. Special Publication of the Society for American Archeology, Washington, D.C.

Morris, William (editor)

1969 American Heritage Dictionary of the English Language. American Heritage and Houghton Mifflin, New York.

Mueller, James W. (editor)

1975 Sampling in Archaeology. University of Arizona Press, Tucson.

Neuschwander, K. M.

1976 The Concerns of Industry. In Symposium on Dynamics of Cultural Resource Management, edited by Ray $T$. Matheny and Dale L. Berge. Archeological Report No. 10:44-49. USDA Forest Service, Southwestern Region.

O'Callaghan, Jerry A.

1960 The Disposition of the Public Domain in Oregon. Memorandum of the Chairman to the Committee on Interior and Insular Affairs, United States Senate, 86 th Congress, 2nd Session, Washington, D.C.

Ogden, Daniel M., Jr.

1971 How National Policy is Made. Lecture given under Herman Royer Program in Political Economy, University of California, Berkeley. 
Oregon Department of Transportation, Parks and Recreation Branch, Oregon State Historic Preservation Office

1976 Statewide Inventory of Historic Sites and Buildings. Lake County. Oregon Department of Transportation, Parks and Recreation Branch, Oregon State Historic Preservation Office, Salem, Oregon.

Oregon Iand Conservation and Development Commission

1973 Oregon Land Use Handbook. Oregon Land Conservation and Development Commission, Salem, Oregon.

Palacios, Victoria and Robert L. Johnson

1976 An Overview of Archaeology and the Law: Seventy Years of Unexploited Protection for Prehistoric Resources. Notre Dame Lawyer 51:706-721.

Pastron, Allen G., Patrick S. Hallinan, and C. William Clewlow, Jr. (editors)

1973 The Crisis in North American Archaeology. Kroeber Anthropological Society, Special Publication No. 3.

Phillips, Robert W.

1974 Proposal for the Inception and Management of Archeological Wilderness Areas. U.S. Department of the Interior, Bureau of Land Management, Technical Note 252 .

Plog, Fred

1976 Cultural Resource Management, The "New Archeology", and Graduate Training. Paper presented at the American Anthropological Conference, San Francisco.

Public Land Law Review Commission

1970 One Third of the Nation's Land. A Report to the President and to the Congress by the Public Land Law Review Commission. U.S. Government Printing Office, Washington, D.C. 
Reaves, Roy W. , III

1976 Historic Preservation Laws and Policies: Background and History. In Symposium on Dynamics of Cultural Resource Management, edited by Ray T. Matheny and Dale L. Berge. Archeological Report. No. 10:15-23. USDA Forest Service, Southwestern Region.

Roney, John

1979 Personal communication regarding determination of impacts caused by livestock trampling.

Rudy, Jack R.

1976 National Environment Policy Act and Cultural Resources. In Symposium on Dynamics of Cultural Resource Management, edited by Ray T. Matheny and Dale L. Berge. Archeological Report No. 10:38-43. USDA Forest Service, Southwestern Region.

Schiffer, Michael B. and George J. Gumerman

1977 Conservation Archaeology. A Guide for Cultural Resource Management Studies. Academic Press, New York.

Schiffer, Michael B. and John H. House

1977 Cultural Resource. Management and Archaeological Research: The Cache Project. Current Anthropology $18(1): 43-68$.

Scovill, Douglas H.

1974 a History of Archaeological Conservation Policy and the Moss-Bennett Bili. In Proceedings of the 1974 Cultural Resource Management Conference, edited by William D. Lipe and Alexander J. Lindsay, Jr. Museum of Northern Arizona, Technical Series No. $14: 1-11$.

1974b Gearing Up for Contract Archaeology. In Proceedings of the 1974 Cultural Resource Management Conference; edited by William $D$. Lipe and Alexander J. Lindsay, Jr. Museum of Northern Arizona, Technical Series No. 14:57-61. 
Scovill, Douglas H., Garland J. Gordon, and Keith M. Anderson

1972 Guidelines for the Preparation of Statements on Environmental Impact on Archeological Resources. U.S. Department of the Interior, National Park Service, Arizona Archeological Center, Tucson.

Seaman, N.G.

1946 Indian Relics of the Pacific Northwest. Binfords and Mort, Portland, Oregon.

Sneed, Paul G.

1976 Public Archaeology and Volunteer Archaeological Wardens in British Columbia. Datum 2(1):2-3.

South, stanley

1977 Method and Theory in Historical Archeology. Academic Press, New York.

Stephenson, Robert L.

1968 You and Your Arrowheads. The Nevada Archeological Survey Reporter II(1):12-20.

Strong, Emory M.

1969 Stone Age in the Great Basin. Binfords and Mort, Portland, Oregon.

Talmage, Valerie, Olga Chesler, and Staff of Interagency Archeological

Services

1977 The Importance of Small, Surface, and Disturbed Sites as Sources of Significant Archeological Data. U.S. Department of the Interior, National Park Service, Cultural Resource Management Studies. Washington; D,C.

Thompson, Raymond $\mathrm{H}$.

1974 Institutional Responsibilities in Conservation Archaeology. In Proceedings of the 1974 Cultural Resource Management Conference, edited by William D. Lipe and Alexander J. Lindsay, Jr. Museum of Northern Arizona, Technical Series No. 14:13-24. 
U.S. Department of the Interior,

Bureau of Land Management

1975 Bureau Manual 1600 - Planning. U.S. Department of the Interior, Bureau of Land Management, Office of the Director, Washington, D.C.

1976 Public Land Statistics. U.S. Department of the Interior, Bureau of Land Management. U.S. Government Printing Office, Washington, D.C.

1977 Bureau Manual 1201 - Organization Management. U.S. Department of the Interior, Bureau of Land Management, Office of the Director, Washington, D.C.

1978a BLM Facts, Oregon and Washington 1978. U.S. Department of the Interior, Bureau of Land Management.

1978b Bureau Manual 8100 - Cultural Resource Management. U.S. Department of the Interior, Bureau of Land Management, Office of the Director, Washington, D.C.

1978c Bureau Manual 8110 - Cultural Resource Inventory and Evaluation. U.S. Department of the Interior, Bureau of Land Management, Office of the Director, Washington, D.C.

1978d Bureau Manual 8111 - Cultural Resource Inventory and Evaluation (Uplands). U.S. Department of the Interior, Bureau of Land Management, Office of the Director, Washington, D.C.

1978e Federal Land Policy and Management Act Proposed Planning Regulations. U.S. Department of the Interior, Bureau of Land Management. Federal Register, December 15, 1978, Part IV.

$1978 \mathrm{f}$ Cultural Resource Management Plan Guidelines. Instruction Memorandum No. 78-361. U.S. Department of the Interior, Bureau of Land Management, Associate Director's Office, Washington, D.C.

1979a Summary of Fiscal Year 1978 Antiquities Permits, Information Memorandum No. 79-68. U.S. Department of the Interior, Bureau of Land Management, Washington, D.C.

1979b Guidelines for Cultural Resource Evaluation. Instruction Memorandum No. 78-339. U.S. Department of the Interior, Bureau of Land Management, Washington, D.C. 
U.S. Department of the Interior, National Park Service

1976 A status Report to the Archeological Community. U.S. Department of the Interior, National Park Service, Interagency Archeological Services Division, Washington; D.C.

U.S. Department of the Interior, Office of the Secretary

1978 (4310-03) office of the secretary (Secretary's Order 3017) Heritage Conservation and Recreation Service. Federal Register, Thursday, February 23, $1978,43(37): 7482-7483$.

Utley, Robert M.

1973 Archeology and the National Register. Historical Archaeology $7: 63-67$.

1978 The Role of the Advisory Council on Historic Preservation in the Protection of Cultural Resources. Statement to National Planning Conference for Cultural Resource Management and Preservation, S.t. Louis.

Verner, Roy s.

1975 Problems in Resource Management. Paper presented at the 40th Annual Meeting of the Society for American Archeology, Dallas.

Vivian, R. Gwinn

1973 Archaeological Resources and Land-Use Planning, An Archaeologist Speaks. Field Notes, Arizona Bureau of Mines $3(1): 1-7$.

Walker, Neal. (Lake County District Attorney)

1979 Personal communication regarding prosecution of antiquities violations under oregon state statutes on federal lands.

Wendorf, Fred et al.

1978 The Fort Burgwin Conference on National Archaeological policies. The Fort Burgwin Conference on National Archaeological Policies, Taos, New Mexico. 
Wildesen, Leslie E.

1974 Archaeologists and Planners: The Uses and Misuses of Predictive Models. Paper presented at the 1974 Annual Meeting of the Society for California Archaeology, Riverside.

1977 a Cultural Resource Management. A Guidebook of Procedures and Techniques for Managing Historical and Archaeological Resources. USDA Forest Service, Pacific Northwest Region, Portland, Oregon.

1977b Analysis of Project-Related Impacts on Archaeological Resources. On file USDA Forest Service, Pacific Northwest Region, Portland, Oregon.

1979a Coming of Age in Applied Archaeology: A Review of Anthropology in Historic Preservation and Conservation Archaeology. Reviews in Anthropology, in press.

1979b Getting Us AIL Together: Cultural Resources Contracting in the Pacific Northwest. Paper presented at Symposium on Ethics of Contracting, Annual Meeting of the Society for American Archaeology, Vancouver, British Columbia.

Wildesen, Leslie E. and Y. T. Witherspoon

1978 Archaeology for the People: The Ethics of Public Archaeology. Paper presented at the 31st Annual Northwest Anthropological Conference, Pullman washington.

Wilson; Rex L.

1975 Changing Directions in the Federal Archeology Programs. Paper presented at the 74 th Annual Meeting of American Anthropological Association, San Francisco.

1976a Response to Public Law 93-291. In Symposium on Dynamics of Cultural Resource Management, edited by Ray T. Matheny and Dale L. Berge. Archeological Report No. 10:9-14. USDA. Forest Service, Southwestern Region.

1976b Archeological and Historic Data Recovery Program. Fiscal year 1976. U.S. Department of the Interior, National Park Service, Washington, D.C. 
Witherspoon, Younger $T$.

1978 Personal communication regarding research in cultural resources under aspects of the Bureau manual.

Woodward, Arthur

1965 Indian Trade Goods. An Oregon Archaeological Society Publication.

Worf, William A.

1975 Cultural Values in the Wilderness: The Wilderness Perspective. In The Wilderness and Cultural Values: A Symposium, edited by Dee F. Green. Archeological Report No. 7:22-29. USDA Forest Service, Southwestern Region.

York, Robert and John Roney

1977 Nevada BLM Inventory and Data Retrieval Systems What Some Sheets of Mylar Can Mean to the Great Basin Archeologist. Nevada Archeological Survey Reporter $10(1): 2-8$.

Young, Jon Nathan

1975 Historic Preservation in the Wilderness. In The Wilderness and Cultural Values: A Symposium, edited by Dee F. Green. Archeological Report No. 7:5-6. USDA Forest Service, Southwestern Region.

Federal Statutes and Code of Federal Regulations Cited Antiquities Act of 1906: P.I. 59-209; 34 Stat. 225; 16 U.S.C. 432,433 .

Department of Transportation Act of 1966: P.L. 89-670; 80 stat. 931; 49 U.S.C. 1653.

Executive Order 11593, Protection and Enhancement of the Cultural Environment: 36 F.R. 8921, May 13, 1971.

Federal Land Policy and Management Act of 1976: P.L. 94579; 90 stat. $2743 ; 43$ U.S.C. 1701.

Geothermal Steam Act of 1970: P.L. 91-581; 84 Stat. 1566; 30 U.S.C. 1001-1025. 
Historic Sites Act of 1935: P.L. 74-292; 49 Stat. 666; 16 U.S.C. 461.

Mineral Leasing Act of 1920: P.I. 66-146; 41 Stat. 437 as amended and supplemented; 30 U.S.C. 181.

National Environmental Policy Act: P.I. 91-190; 83 Stat. $852 ; 42$ U.S.C. 4321 .

National Historic Preservation Act: P.I. 89-665; 80 Stat. 915; 16 U.S.C. 470 . As amended P.L. 94-422, 90 Stat. 1313; and P.I. 94-458, 90 stat. 1939.

Reservoir Salvage Act of 1960: P.L. 86-523; 74 Stat. 220, $221 ; 16$ U.S.C. 469. As amended P.L. 93-291; 88 Stat. $174 ; 16$ U.S.C. 469

36 CFR 60: National Register of Historic Places, Nominations by State and Federal Agencies, Guidelines.

36 CFR 63: Procedures for Requesting Determination of Eligibility for Inclusion in the National Register, Guidelines.

36 CFR 64: Criteria and Procedures for the Identification of Historic Properties, Guidelines.

36 CFR 65: Recovery of Scientific, Prehistoric, Historic, and Archeological Data, Procedures for Coordination and Notification, Guidelines.

36 CFR 66: Recovery of Scientific, Prehistoric, Historic, and Archeological Data, Methods, Standards, and Reporting Requirements, Guidelines.

36 CFR 800: Procedures for the Protection of Historic and Cultural Properties, Guidelines.

40 CFR 1500: Council on Environmental Quality, Guidelines.

43 CFR Part 3 and DM Part 310.7.6:Uniform Rules and Regulations.

43 CFR 1600: Planning, Programming, and Budgeting, Guidelines. 